\title{
1 The Lomfjorden Fault Zone in eastern Spitsbergen
}

2 (Svalbard)

3 NOT FINAL

4 Karsten Piepjohn $^{1}$, Winfried Dallmann ${ }^{2}$, and Synnøve Elvevold ${ }^{3}$

$5{ }^{1}$ Federal Institute for Geosciences and Natural Resources, Stilleweg 2, 30655 Hannover,

6 Germany, Karsten.Piepjohn@bgr.de

$7 \quad{ }^{2}$ Institute of Geosciences, UiT The Arctic University of Norway, P.O.Box 5060 Langnes, 9037

8 Troms $\phi$, Norway, winfried.dallmann@uit.no

$9{ }^{3}$ Norsk Polarinstitutt, Framsenteret, Hjalmar Johansens gate 14, 9296 Troms $\phi$, Norway,

10 elvevold@npolar.no

13 ABSTRACT

15 The Lomfjorden Fault Zone in the eastern part of Spitsbergen is one of the prominent structures

16 in Svalbard oriented parallel to the continental margin of the Barents Shelf. It consists of a

17 network of three N-S striking major faults (Veteranen, Lomfjorden, and Agardhbukta faults),

18 two N-S striking reverse faults (Lomfjella and Bjørnfjellet reverse faults), and a number of NE-

19 SW and NNW-SSE striking normal, reverse, and strike-slip faults. Structural data collected

20 during fieldwork in the northern and central segments of the fault zone, in combination with

21 published data from the southernmost segment, indicate that $\mathrm{N}-\mathrm{S}$ striking reverse faults in the

22 Lomfjorden Fault Zone were caused by convergence transferred from the West Spitsbergen

23 Fold-and-Thrust Belt eastwards along detachments during an initial phase of the Eurekan

24 deformation in the early Eocene. The W-E contraction was followed by sinistral and dextral

25 strike-slip tectonics along the Lomfjorden Fault Zone during a later phase of the Eurekan

26 deformation in the late Eocene. The NNW-SSE striking reverse and normal faults are oriented

27 obliquely between the N-S striking, en-échelon Lomfjorden and Agardhbukta faults. Shortening

28 and extension across these, respectively, can be explained by left-stepping contractional overstep

29 or left-stepping wrench faults in an overall dextral and left-stepping extensional overstep or left-

30 stepping wrench faults in an overall sinistral, $\mathrm{N}-\mathrm{S}$ trending strike-slip system. It was not possible 
31 to determine if the sinistral phase pre-dated the dextral one or vice versa. The presence of a large

32 granite massif, the Newtontoppen Granite, is suspected to influence or even control the course of

33 the faults and their transfer systems. The involvement and reactivation of pre-existing

34 Carboniferous and even older structures and the superimposition of convergent and lateral

35 movements along the Lomfjorden Fault Zone is similar to large fault zones in North Greenland

36 and on Ellesmere Island, indicating that it represents an important element of the Eurekan

37 Orogeny during the final break-up of Laurasia.

\section{INTRODUCTION}

The archipelago of Svalbard is located at the northwestern margin of the Barents Shelf (Fig. 1). In the eastern part of the main island of Spitsbergen, two major N-S striking fault zones are exposed. The western one is the Billefjorden Fault Zone in central-eastern Spitsbergen (e.g., Harland et al., 1974; Manby, 1990; Manby et al., 1994; McCann and Dallmann, 1996; Harland, 1997; Maher and Braathen, 2011; Braathen et al., 2011; Dallmann, 2015), separating the Northeastern Basement Province and the Devonian Andrée Land Basin (Old Red Sandstone) (Fig. 2A). The eastern one is the Lomfjorden Fault Zone, which consists of three N-S striking major faults (Dallmann, 2015). The western fault is represented by the Veteranen Fault or 'Veteranen Line' (Harland et al., 1992; Harland, 1997), which sub-divides the Northeastern

51 Basement Province into the Western Ny-Friesland Terrane in the W and the Nordaustlandet

52 Terrane in the E (e.g., Gee et al., 1995; Harland, 1997; Gee and Teben'kov, 2004; Fig. 2A). The

53 central fault is the Lomfjorden Fault, which separates Neoproterozoic rocks in the W, partly

54 overlain by Early Carboniferous deposits, from middle Carbonifereous and younger sedimentary 55 rocks in the E (Figs. 2B and 3). The eastern fault of the Lomfjorden Fault Zone is the 56 Agardhbukta Fault (Akademikarbreen Fault in Dallmann, 2015; Fig. 2B), which continues 57 southwards to Agardhdalen W of Storfjorden (Miloslavskij et al., 1993b). Prior to this study, the Lomfjorden and Agardhbukta faults were shown as a single, curved fault on most geological

59 overview maps (Nathorst, 1910; Odell, 1927; Frebold, 1935; Hjelle and Lauritzen, 1982;

60 Harland, 1979, 1997; Dallmann et al., 2002). Another fault exists E of the Lomfjorden Fault

61 Zone: the Storfjorden Fault Zone was detected by seismic observations in Storfjorden between 
Spitsbergen in the W and Barentsøya and Edgeøya in the E (Eiken, 1985; Fig. 2A). It is

63 suggested to continue northward along the glacier Hinlopenbreen (Fig. 3) with a northward-

64 decreasing offset (Dallmann, 2015).

Most authors agree that the dominant tectonic activity in the southern segment of the Lomfjorden Fault Zone occurred in the Paleogene (e.g., Kellogg, 1975; Harland, 1979; Andresen et al., 1988, 1992, 1994; Larsen, 1988; Nøttvedt et al., 1988; Miloslavskij et al., 1993b). During that time, the western part of Spitsbergen was affected by significant folding and thrusting related to the formation of the West Spitsbergen Fold-and-Thrust Belt (e.g., Harland, 1969, 1973a, b, 1997; Birkenmajer, 1972a, b, 1981; Harland and Horsfield, 1974; Maher and Craddock, 1988; Dallmann et al., 1993; Braathen et al., 1995; Bergh et al., 1997; Tessensohn, 2001; Bergh and Grogan, 2003; Leever et al., 2011; Dallmann, 2015: Fig. 2A). Equivalent fold-and-thrust belt structures occur in North Greenland (e.g., Soper et al., 1982; Soper and Higgins, 1991; von Gosen and Piepjohn, 1999, 2003; Piepjohn and von Gosen, 2001; Tegner et al., 2011) and in the

76 Canadian Arctic Archipelago where they are considered as a consequence of the Eurekan

77 Orogeny (e.g., Thorsteinsson and Tozer, 1970; Higgins and Soper, 1983; Okulitch and Trettin, 78 1991; Piepjohn et al., 2000b, 2008; Saalmann et al., 2005, 2008; Harrison, 2008; Tessensohn et 79 al., 2008; von Gosen et al., 2008).

81 The southernmost segment of the Lomfjorden Fault Zone (Fig. 2B) displays orthogonal 82 contraction during the Paleogene formation of the West Spitsbergen Fold-and-Thrust Belt 83 (Kellogg, 1975; Andresen et al., 1988, 1992, 1994; Larsen, 1988; Nøttvedt et al., 1988;

84 Miloslavskij et al., 1993b). Until now, little is known about the structural architecture,

85 kinematics, and age of deformations along the northern and central segments of the Lomfjorden

86 Fault Zone (Fig. 2B). Before, it was interpreted either as a down-to-the-east normal fault on

87 previous geological maps (Hjelle and Lauritzen, 1982; Harland, 1997) or as dominated by

88 reverse faults due to W-E shortening (Bergh et al., 1994).

90 In this paper, we describe results of structural fieldwork during the 2001-2009 Norwegian 91 mapping program (Dallmann et al., 2009, 2011) in the northern and central segments of the 92 Lomfjorden Fault Zone. The main study area was situated in the eastern part of Ny-Friesland 
93 between Kapp Fanshawe in the $\mathrm{N}$ and Andromedafjellet in the S (Fig. 3). In addition, some

94 outcrops were studied in Olav V Land between Pachtusovfjellet and Malte Brunfjellet (Fig. 2B).

95 Our results lead to kinematic interpretations of the brittle fault tectonics in the area, which

96 support previously documented convergent tectonics across the fault zone (Andresen et al., 1988,

97 1992, 1994; Haremo and Andresen, 1992; Miloslavskij et al., 1993b; Bergh et al., 1994). In

98 addition, field observations show that the northern and central segments of the Lomfjorden Fault

99 Zone were also affected by strike-slip deformation. The convergent and lateral displacements can

100 be linked to movements along the southernmost segment of the fault zone and to the West

101 Spitsbergen Fold-and-Thrust Belt.

102

103

104

GEOLOGIC SETTING

105

106 The basement in northeastern Spitsbergen consists of Meso- and Paleoproterozoic high-grade 107 metamorphic rocks of the Atomfjella Complex in the W (Western Ny-Friesland Terrane) and

108 low-grade metamorphic to unmetamorphosed Neoproterozoic to Early Paleozoic sedimentary 109 rocks of the Lomfjorden Supergroup in the E (Nordaustlandet Terrane; Fig. 2A). These terranes 110 are separated by the Eolussletta Shear Zone (see below) with the 'Veteranen Line' (Harland et al., 111 1992; Harland, 1997) or Veteranen Fault marking the eastern boundary of the ductile shear zone 112 (Figs. 3 and 4).

114 The more than $5 \mathrm{~km}$ thick succession of unmetamorphosed to low-grade sedimentary rocks E of 115 the Veteranen Fault is subdivided into the Neoproterozoic Veteranen, Akademikarbreen, 116 Polarisbreen, and the Cambro-Ordovician Oslobreen groups (Harland et al., 1966; Harland, 117 1997). The succession was folded during the main phase of the Caledonian Orogeny (e.g., 118 Harland et al., 1992; Harland, 1997; Dallmann, 2015). The structural architecture is dominated 119 by km-scale, NNW-SSE to N-S trending anticlines and synclines and some steeply W-dipping 120 reverse faults (Figs. 3 and 4). The Caledonian $F_{1}$-folds are characterized by moderately to steeply

121 WSW- and ENE-dipping limbs, subvertical axial planes, subvertical cleavage planes $\mathrm{S}_{1}$, and 122 approximately $\mathrm{N}-\mathrm{S}$ trending $\delta_{1}$-intersection lineations parallel to $\mathrm{B}_{1}$-fold axes (Fig. 5). 
124 The late Caledonian development was characterized by ductile to brittle sinistral shearing along 125 the Billefjorden Fault Zone in Late Silurian and Early Devonian times (Manby et al., 1994) and 126 by the juxtaposition of the Western Ny-Friesland and the Nordaustlandet terranes along the 127 Eolussletta Shear Zone (Manby, 1990; Manby and Lyberis, 1992; Manby et al., 1994; Lyberis 128 and Manby, 1999; Figs. 3 and 4). The latest phase of the Caledonian Orogeny is represented by 129 the intrusion of undeformed, post-tectonic granitoids of the Chydeniusbreen Granitoid Suite, 130 consisting mainly of the Newtontoppen Granite (Fig. 3) with Silurian to Devonian ages of 385 $131406 \mathrm{Ma}$ (K-Ar, Gayer et al., 1966), $432 \pm 10 \mathrm{Ma}$ (Rb-Sr, Teben'kov et al., 1996), and $430 \pm 0.7$ 132 Ma (U-Pb, Myhre, 2005).

134 The Caledonian Orogeny was followed by the development of the Old Red Sandstone basin W 135 of the Billefjorden Fault Zone during the latest Silurian (?) and entire Devonian (e.g., Suess, 136 1888; Frebold, 1935; Orvin, 1940; Friend, 1961; Gee and Moody-Stuart, 1966; Murašov and 137 Mokin, 1979; Piepjohn et al., 2000a; Piepjohn and Dallmann, 2014; Fig. 2A). The sedimentary 138 succession of the Old Red Sandstone basin was deformed during the Svalbardian (=Ellesmerian) 139 Event (e.g., Vogt, 1928; Friend and Moody-Stuart, 1972; Piepjohn, 1994, 2000; McCann, 2000;

140 Piepjohn et al., 2000a). It is still a matter of debate whether the Svalbardian deformation was 141 caused by sinistral strike-slip or by E-W shortening (e.g., Harland et al., 1974; Lamar et al., 142 1986; Manby et al., 1994; Piepjohn, 1994, 2000; McCann and Dallmann, 1996; Bergh et al., 143 2011). It should be noted that no Svalbardian structures have been found so far in the 144 Northeastern Basement Province E of the Billefjorden Fault Zone (Dallmann, 2015).

146 The Svalbardian Event was followed by the deposition of the Viséan to possibly lowermost 147 Serpukhovian Billefjorden Group (Playford, 1962/63; Cutbill and Challinor, 1965; Scheibner et 148 al., 2012). Deposits of this unit occur on the mountain plateau of Lomfjella to the W of the 149 Lomfjorden Fault (Fig. 3), where they unconformably overly Neoproterozoic rocks of the 150 Veteranen Group. An isolated and small occurrence of coaly shales and approximately $100 \mathrm{~m}$ of 151 poorly exposed red clastic sedimentary rocks within a NNE-SSW striking fault-bounded slice 152 within a branch of the Lomfjorden Fault located S of Kapp Fanshawe (Dallmann et al., 2009), 153 has yielded a similar palynological age (Scheibner et al., 2012; Fig. 3). Apart from this exposure, 154 the Billefjorden Group does not occur E of the Lomfjorden Fault. This suggests that the 
155 Lomfjorden Fault was already active in the early Carboniferous (Bergh et al., 1994; Dallmann, 156 2015).

158 In the middle to late Carboniferous, Spitsbergen was a site of halfgraben formation, such as the 159 St. Jonsfjorden and Billefjorden troughs (Cutbill and Challinor, 1965; Steel and Worsley, 1984;

160 Dallmann, 1999, 2015, and references therein; Braathen et al., 2011). Red sandstone and shale of 161 the middle Carboniferous Malte Brunfjellet Formation occur in the vicinity of the Lomfjorden

162 Fault with a possible extent eastwards to Nordaustlandet - collectively assigned to the 163 Lomfjorden Basin (Dallmann, 2015). After the Moscovian, most of the large fault zones in 164 Svalbard were apparently more or less inactive until the beginning of the break-up of the Arctic 165 and North Atlantic oceans.

The youngest deposits in the study area are mostly horizontal strata of late Carboniferous to

168 Permian limestones of the Gipsdalen Group (Wordiekammen and Gipshuken formations) and sandstones and cherts of the Tempelfjorden Group (Kapp Starostin Formation). They unconformably overlie the folded Neoproterozoic sedimentary successions E of the Lomfjorden

171 Fault (Dallmann et al., 2009, 2011; Fig. 4) and also the middle Carboniferous rocks. The

172 Carboniferous and Permian sedimentary units are intruded by a number of dolerite sills (e.g.,

173 Gayer et al., 1966; Halvorsen, 1974; Dallmann et al., 2009, 2011) of Early Cretaceous age

174 (Corfu et al., 2013; Senger et al., 2014) in connection with the volcanic activity of the HALIP 175 (High Arctic Large Igneous Province; e.g., Maher, 2001). Svalbard was subjected to mutiple deformational events in connection with the North-Atlantic and Eurasian Basin rift development

177 during the Cenozoic including the formation of the West Spitsbergen Fold-and-Thrust Belt and a 178 number of subsequent reverse, transform-related and extensional fault systems (e.g., Talwani and 179 Eldholm, 1977; Srivastava, 1978, 1985; Vink, 1982; Srivastava and Tapscott, 1986; De Paor et 180 al., 1989; Tessensohn and Piepjohn, 2000; Faleide et al., 2010; Døssing et al., 2013; Dallmann, 181 2015; Doré et al., 2016; Piepjohn et al., 2015, 2016; Gion et al., 2017; Figs. 1 and 2). 
186 Our geological mapping in the study area has shown that the northern und central segments of

187 the Lomfjorden Fault Zone are composed of different sets of faults with different orientations

188 (Dallmann et al., 2009, 2011; Fig. 3):

190 (1) The main direction is represented by three approximately $\mathrm{N}-\mathrm{S}$ striking major faults. The 191 westernmost Veteranen Fault can be traced from northern Ny-Friesland towards the nunatak

192 Terrierfjellet NE of Billefjorden in the S (Dallmann et al., 2002, 2004, 2009, 2010, 2011;

193 Elvevold and Dallmann, 2011; Fig. 2B). It separates the Eolussletta Shear Zone in the W and 194 sedimentary rocks of the Veteranen Group in the E. The late Caledonian age of the Veteranen 195 Fault is supported in the S at Terrierfjellet, where the juxtaposed West Ny-Friesland and 196 Nordaustlandet terranes are overlain by middle Carboniferous and younger sedimentary rocks 197 (Dallmann et al., 2004; Fig. 2B). In the northern segment, a post-Carboniferous reactivation of 198 the Lomfjorden Faut is indicated by downfaulted early Carboniferous strata SE of Lomfjella 199 (Fig. 3). The central Lomfjorden Fault is exposed at the W-coast of Lomfjordhalvøya S of Kapp 200 Fanshawe and E of the mountains Geren and Freken (Fig. 3). Its southern continuation can be 201 assumed SSW of Glintbreen and SW of Vinkelen due to the large stratigraphic jump between 202 both sides of the glacier valleys. Mostly, it separates Neoproterozoic sedimentary rocks in the W 203 from down-faulted Carboniferous to Permian deposits in the E. Towards the S, the Lomfjorden 204 Fault continues either on the W-side or E-side of the Silurian/Devonian Newtontoppen Granite 205 (Fig. 3). In the E, the Agardhbukta Fault (Fig. 3) can be followed with some certainty from 206 Oslobreen southward to and along Akademikarbreen with exposures at Kirtonryggen (northern 207 segment) (Fig. 3), Vivienberget, Malte Brunfjellet (central segment), and in the Agardhdalen 208 area in the southern segment (Fig. 2B). It mostly separates Neoproterozoic and Paleozoic 209 sedimentary rocks of the Lomfjorden Group in the W from downfaulted Carboniferous to 210 Permian deposits in the E (Figs. 2B and 3). North of Oslobreen, it is not a straight fault line, but a 211 fault system with variably oriented strands seen at Ditlovtoppen and Raudberget. Most segments 212 of the Agardhbukta Fault are covered by glaciers, but its existence can be inferred from high 213 mountain areas with Neoproterozoic and Paleozoic rocks in the W (Dracofjella,

214 Andromedafjellet, Golitsynfjellet) and lower mountains with horizontal Carboniferous and 215 Permian strata in the E (Emblafjellet, Rotfjellet, Kassiopeiafjellet, Pachtusovfjellet; Figs. 3, 4, 
216 and 6). The Carboniferous unconformity and underlying Neoproterozoic rocks are nowhere

217 exposed E of the Agardhbukta Fault except for a small area at Oslobreen (Figs. 3, 4, and 15).

219 (2) Important structural elements of the Lomfjorden Fault Zone are N-S striking reverse faults.

220 Bergh et al. (1994) reported that the northern segment of the fault zone consists of a set of

221 subparallel, partly curved and variably E- and W-dipping, basement-involved reverse faults.

222 Between the Veteranen and Lomfjorden faults, two steeply ENE-dipping, 7 and $20 \mathrm{~km} \mathrm{long,}$

223 reverse faults are exposed at Lomfjella W of Lomfjorden (Lomfjella Reverse Faults) (Fig. 3).

224 South of Lomfjorden, the $15 \mathrm{~km}$ long and steeply W-dipping Bjørnfjellet Reverse Fault is

225 exposed E of Bjørnfjellet and at Løveryggen (Fig.3). Bergh et al. (1994) concluded that both

226 reverse faults represent a pop-up structure above an E-directed thrust (Bjørnfjellet Reverse Fault)

227 and a W-directed back thrust (Lomfjella Reverse Faults). Both reverse faults have carried

228 Neoproterozoic rocks over Carboniferous deposits and early Cretaceous dikes. The revserse

229 faults have reactivated inherited Carboniferous normal faults, steeply dipping Neoproterozoic

230 strata and Caledonian thrusts (Bergh et al., 1994). No cross-cutting relationships of these reverse

231 faults with the N-S striking master faults were found. The Lomfjella Reverse Faults and the

232 Bjørnfjellet Reverse Fault do not continue across Lomfjordbotnen towards the SSE or NNW,

233 respectively, but are probably limited by the NE-SW striking Geren Fault (Fig. 3).

(3) Several NE-SW striking faults with lengths of hundreds-of-meters up to $15 \mathrm{~km}$ (Fig. 3)

236 mostly follow the major NE-SW valleys and glaciers and are not exposed, although needed to

237 explain the outcrop patterns. Between the Veteranen and Lomfjorden faults in the northern part

238 of the study area, three NE-SW striking faults could be mapped along the valleys of

239 Gullfaksebreen and Faksebreen, and through Lomfjordbotnen at the southern end of Lomfjorden

240 (Geren Fault; Fig. 3). The faults at Gullfaksebreen and Faskebreen cut through NNW-SSE

241 trending km-scale Caledonian anticlines and synclines and the Western Lomfjella Reverse Fault

242 with dextral offsets in the range of 1 to $2 \mathrm{~km}$ (Fig. 3). This is supported by the occurrence of

243 small-scale NE-SW striking faults visible on aerial photographs with right-lateral offsets of

244 steeply inclined Neoproterozoic rocks and Caledonian structures. The NE-SW striking Geren

245 Fault between the Veteranen Fault and the Lomfjorden Fault through Lomfjordbotnen is

246 indicated by the offset of different Caledonian structures between Lomfjella and Bjørnfjellet. It is 
exposed onshore at Geren and Freken mountains (Fig. 3). Farther S, NE-SW striking faults are

248 documented between the Lomfjorden Fault and the Agardhbukta Fault (Fig. 3). There, the largest

249 fault follows the glacier Chydeniusbreen. Although not exposed, the trace of the fault can be

250 inferred from the jump of the Carboniferous unconformity from $500 \mathrm{~m}$ above sea level in the

251 NW to more than $800 \mathrm{~m}$ in the SE. The NNW-SSE trending Caledonian Ursafonna Anticline in

252 the Neoproterozoic rock units is dextrally offset by apparently ca. $3 \mathrm{~km}$ along the fault (Fig. 3).

253 In addition, there are a number of minor NE-SW striking faults in the Dracoisen area (Fig. 3).

255 (4) Between the Lomfjorden and Agardhbukta faults, some NNW-SSE striking faults are

256 exposed in the Oslobreen area (Fig. 3). There, the Dolerittfjellet Reverse Fault carries

257 Neoproterozoic rock units ENE-wards over Carboniferous sedimentary rocks and Cretaceous

258 dolerite sills. Farther E, the parallel Sillhøgda Fault is characterized by a normal, down-to-the-

259 SW sense of displacement. Both faults are only locally exposed at Sillhøgda. Their continuations

260 to the NNW and SSE and relationships to the N-S striking master faults are uncertain. Another

261 NNW-SSE striking fault is locally exposed at Raudberget where it separates Neoproterozoic

262 rocks in the ENE from Carboniferous and underlying Neoproterozoic rocks in the WSW (Fig. 3).

STRUCTURES AND THEIR INTERPRETATION

267 Below, we describe and interpret, from $\mathrm{N}$ to $\mathrm{S}$, structural field observations from different 268 outcrops along the Lomfjorden and Agardhbukta faults. The locations are shown in Figure 6.

269 Most of the structural data were not measured in outcrops directly on a fault or within a fault

270 zone because most parts of the fault segments are covered by water or glaciers and exposures are

271 rare (Figs. 3 and 6). Therefore, most structures were observed and measured as close as possible

272 to the faults or fault zones or in blocks between them. In some figures we have inserted

273 schematic diagrams showing pure shear-ellipses and ideal fault and shear plane orientations in

274 strike-slip regimes to provide a reference for configurations of structural elements in the various

275 possible scenarios discussed here. 
279 Observations. At the coastal cliffs SSW of Kap Fanshawe, a NNE-SSW striking strand of the 280 northernmost segment of the Lomfjorden Fault is exposed within Neoproterozoic rocks of the 281 Akademikarbreen Group (Figs. 6 and 7A). East of the major fault, the Neoproterozoic rocks dip 282 gently towards the E and are cut by a brittle NE-SW striking fault zone with fault breccias. This 283 fault zone is characterized by left-lateral offsets of the E-dipping bedding planes with 284 displacements up to a few dm (Fig. 7B). This is supported by sinistral slickenside lineations 285 along cm-scale shear planes in the vicinity of the fault (Fig. 7C).

To the W of the NNE-SSW striking fault, Neoproterozoic rocks are affected by a NNE-dipping 288 thrust with NE-dipping strata in the hanging wall and an anticline-syncline pair in the footwall 289 (Fig. 7B). The rocks are folded around gently E-plunging $\mathrm{F}_{2}$-folds (Fig. 7C) with fold axes 290 perpendicular to the general N-S trend of the Caledonian $\mathrm{F}_{1}$-anticlines and synclines (compare 291 Fig. 5). The E-plunging fold structures and the NNE-dipping thrust fault in the outcrop are 292 truncated by the NNE-SSW striking fault.

294 Interpretation. The NE-SW striking cm-scale shear planes with primarily sinistral slickenside 295 lineations and faults with dm-scale sinistral offsets (Fig. 7B and C) indicate sinistral strike-slip 296 along the NNE-SSW striking fault in the centre of the outcrop. This is supported by the presence 297 of sinistral NE-SW striking shear planes and faults subparallel to the master fault (Fig. 7C), and 298 E-W trending $\mathrm{F}_{2}$-folds and a NNE-dipping thrust, with their inferred N-S shortening direction.

299 These data imply sinistral strike-slip movements along this northernmost segment of the 300 Lomfjorden Fault. A few dextral slickenside lineations on cm-scale NNE-SSW shear planes 301 (Fig. 7C) have been observed also in this area. Because only Neoproterozoic rocks are affected 302 by the brittle strike-slip deformation, a precise timing in this outcrop cannot be determined.

303 However, the slice of Viséan deposits of the Billefjorden Group within the parallel fault in the E 304 (Fig. 7A) suggests that a post-Carboniferous age of the strike-slip deformation in the

305 Neoproterzoic rocks is also possible. 
Observations. In the coastal outcrops at Mjølnerfjellet along the E-coast of Lomfjorden (Fig. 6), carbonate rocks of the Akademikarbreen Group are exposed underneath the Carboniferous

311 unconformity (Fig. 3). The bedding planes dip moderately towards the SSW and are affected by

312 NE-dipping fault planes with reverse and normal senses of displacements (Fig. 8A). Lateral

313 movements are indicated by WNW-ESE striking $\mathrm{cm}$-scale shear planes with a few sinistral

314 slickenside lineations and NNE-SSW striking faults with dextral offsets of the Neoproterozoic

315 strata up to a few cm (Fig. 8A).

317 In the $\mathrm{W}$-facing cliffs of Mjølnerfjellet above the limestones of the Akademikarbreen Group, 318 massive Late Carboniferous limestones of the Wordiekammen Formation exhibit a hundreds-of319 meters-scale structure, which is dominated by a gently SSW-dipping basal thrust ramp with 320 horizontal limestones in the footwall and folded limestones in the hanging wall (Fig. 8C). At the 321 top, the $\mathrm{F}_{2}$-folds are truncated by a gently NNE-dipping thrust fault overlain by unfolded planar 322 limestones and cherts (Fig. 8C). In outcrop scale, several m-scale $\mathrm{F}_{2}$-folds have gently SSW323 dipping long limbs and steeply NNE-dipping to partly overturned short limbs indicating a NNE324 vergence of the folds. Tectonic transport to the NNE to NE is supported by reverse slickenside 325 lineations on NE-dipping back thrusts (Fig. 8B). The NNE-SSW shortening is consistent with 326 the orientation of the pole of the best-fit great circle defined by the poles to bedding planes $\mathrm{S}_{0}$ 327 with a WNW-ESE trend of the $\mathrm{F}_{2}$-folds (Fig. 8B). Evidence for lateral-slip movements in the 328 Carboniferous limestones is poor. Only a few NE-SW striking dextral and WNW-ESE striking 329 sinistral fault planes with slickenside lineations were found (Fig. 8B).

Interpretation. The local character of the $\mathrm{F}_{2}$-folds and thrust ramp and the oblique orientation of 332 their NNE-SSW shortening directions with respect to the N-S striking Lomfjorden Fault make it 333 possible that the local shortening was controlled by dextral strike-slip motions along the nearby

334 Lomfjorden Fault (Fig. 8D). This is supported by SW-dipping shear planes with reverse 335 slickensides in the Neoproterozoic and Carboniferous rocks, dextral offsets of limestones of the 336 Akadamikarbreen Group along NNE-SSW striking faults (Fig. 8A) and some cm-scale NE-SW 337 striking shear planes with dextral slickenside lineations in Carboniferous limestones (Fig. 8B), 338 which most likely represent synthetic shear planes (Fig. 8D). In addition, WNW-ESE striking 339 sinistral shear planes can be interpreted as antithetic P'-shears (Tchalenko and Ambraseys, 1970; 
Bartlett et al., 1981) with respect to possible dextral movements along the Lomfjorden Fault

341 (Fig. 8D). However, it is also possible that the NE-SW striking dextral and WNW-ESE striking

342 sinistral shear planes represent a conjugate set of shear planes related to W-E contraction (see

343 below). NE-dipping $\mathrm{cm}$-scale shear planes with normal slickenside lineations in the

344 Akademikarbreen limestones cannot be correlated with a dextral N-S regime (Fig. 8A). It is

345 possible that they represent the NE-SW extension direction within a N-S striking sinistral

346 regime or a phase of later extension. However, the dominant kinematics at Mjølnerfjellet can be

347 interpreted as N-S striking dextral strike-slip along the Lomfjorden Fault (Fig. 8D).

\section{Geren and Freken}

Observations. East of Geren and Freken mountains, about $10 \mathrm{~km} \mathrm{~S}$ of Mjølnerfjellet, the Lomfjorden Fault crops out onshore between Neoproterozoic rocks in the W and Carboniferous strata and a thick Cretaceous dolerite sill in the E (Dallmann et al., 2009; Figs. 3, 6, and 9A).

354 There, moderately ENE-dipping Neoproterozoic rocks of the Veteranen, Akademikarbreen, and Polarisbreen groups are affected by three brittle NE-SW striking faults (Fig. 9A), which

356 represent the exposed strands of the Geren Fault between Lomfjella in the N and Bjørnfjellet in 357 the S (see Fig. 3). It should be noted that these faults do not continue into the Carboniferous 358 limestones and the Cretaceous dolerite sill E of the Lomfjorden Fault (Fig. 9A). Mapping and 359 interpretation of aerial photographs show that the NE-SW faults display lateral dextral offsets of 360 the Neoproterozoic rocks units in the order of some hundreds of m (Fig. 9A). In spite of the 361 dextral offsets of the Neoproterozoic strata, slickenside lineations on subvertical, NE-SW 362 striking, m-scale faults and cm-scale shear planes indicate also sinstral movements (compare Fig. 363 9A and B). Dextral slickensides have been observed on both NNE-SSW striking and some NW364 SE striking $\mathrm{cm}$-scale shear planes, and sinistral shear has also been documented on NNW-SSE 365 striking cm-scale shear planes (Fig. 9B). Reverse slickenside lineations on $\mathrm{cm}$-scale shear planes 366 and dm-scale fault planes indicate both E-W and NW-SE shortening (Fig. 9B).

At Geren and Freken, only Neoproterozoic rocks are affected, while Carboniferous rocks and the 369 dolerite sill to the $\mathrm{E}$ of the fault are unaffected. Therefore, a precise timing of the deformations in 370 this area is not possible. 
372 Interpretation. The nonuniform distribution and orientation of the tectonic fabric elements and

373 kinematic indicators at Geren and Freken cannot be explained by only one deformation. The

374 field observations show that three tectonic scenarios and combinations of them are possible:

(a) In a W-E shortening scenario, the mapped NE-SW faults and measured NNE-SSW striking

377 shear planes with dextral slickensides (Fig. 9B) possibly represent the dextral set of a conjugate

378 set of shear planes and faults $\left(\right.$ Fig. $\left.9 C_{1}\right)$. This would also include the possibility that the apparent

379 right-lateral dextral offsets in the map can be partly caused by SE-side-down displacements.

380 NNW-SSE striking shear planes with sinistral slickensides are the sinistral part of the conjugate

381 set of shear planes and faults (Fig. 9B and $\mathrm{C}_{1}$ ). This $\mathrm{W}-\mathrm{E}$ shortening scenario is supported by

382 steeply E- and W-dipping shear planes with reverse slickensides (Fig. 9B and $\mathrm{C}_{1}$ ).

384 The other two possible scenarios are related to N-S trending strike-slip movements:

(b) NNE-SSW striking dextral and ENE-WSW striking sinistral shear planes and faults can be interpreted as synthetic and antithetic shears, respectively, of dextral movements along the

388 Lomfjorden Fault (Fig. 9B and $\mathrm{C}_{2}$ ).

(c) However, a sinistral N-S scenario is also possible and indicated by NNW-SSE striking sinistral shear planes (synthetic shears), the NE-SW striking dextral faults (P'-shears), by some

392 NW-SE striking dextral shear planes (antithetic shears), and by some SE- and NW-dipping shear 393 planes with reverse slickensides (Fig. 9B and $\mathrm{C}_{3}$ ).

\section{Lomfjella Reverse Faults}

397 Observations. Between the Veteranen Fault in the W and Lomfjorden in the E, the two steeply 398 ENE-dipping Lomfjella Reverse Faults are exposed (Figs. 3 and 4A). The western reverse fault 399 runs from Valhallfonna in the NNW towards Lomfjella in the SSE, and the eastern one is located 400 in the steep coastal cliffs of Lomfjorden E of Lomfjella (Figs. 3 and 10A). The position of both 401 reverse faults was most likely controlled by the orientation of bedding in the km-thick eastern 
402

403

404

405

406

407

408

409

410

411

412

413

414

415

416

417

limb of the Caledonian anticline (Fig. 4A) and by reactivation of pre-extisting Carboniferous normal faults (Bergh et al., 1994). In the S, the Eastern Lomfjella Reverse Fault is truncated by the NE-SW striking Geren Fault and does not appear again in the mountain areas S of Lomfjordbotnen (Fig. 3).

The $70^{\circ}$ E-dipping, $7 \mathrm{~km}$ long, Eastern Lomfjella Reverse Fault carries Neoproterozoic rocks over Early Carboniferous strata and Early Cretaceous dolerites (compare Bergh et al., 1994; Figs. $3,4,6$, and 10). The geological relationships in the field suggest that the displacement is in the range of at least $150 \mathrm{~m}$. The sedimentary rocks above the reverse fault are affected by almost subvertical reverse faults with transports towards the $\mathrm{W}$ and by $\mathrm{W}$ - and E-dipping back thrusts (Fig. 10B). The amounts of displacement along the reverse faults and back thrusts show displacements of several $\mathrm{m}$. The partly gypsiferous layers of the Veteranen Group exhibit a number of dm- to m-scale duplex structures and imbricates (Fig. 10B and C) supporting a tectonic transport upwards to the $\mathrm{W}$.

Interpretation. The $\mathrm{N}-\mathrm{S}$ trending $\mathrm{F}_{2}$-folds related to $\mathrm{W}$-directed reverse faults and $\mathrm{E}$-directed, W- and E-dipping back thrusts support E-W contraction along the Eastern Lomfjella Reverse Fault (Fig. 10A and B). In the Veteranen deposits in the hanging wall, no evidence for strike-slip deformation was found. Some NE-SW striking $\mathrm{cm}$-scale faults and shear planes with dextral slickenside lineations can be interpreted as the dextral set of conjugate shear planes related to W-E shortening (Fig. 10C and D). The second NW-SE striking sinistral set could not be found in this outcrop. This situation is similar to Geren and Freken on the opposite side of Lomfjorden (see above), where the dextral NE-SW faults dominate. Therefore, and following Bergh et al. (1994), we suggest that the Lomfjella Reverse Faults were formed during W-E contraction.

\section{Bjørnfjellet Reverse Fault}

Observations. The Bjørnfjellet Reverse Fault is a N-S striking, approximately $15 \mathrm{~km}$ long and W-dipping fault between Lomfjordbotnen in the $\mathrm{N}$ and Løveryggen in the S (Fig. 3). It represents the dominating structural element in this area $\mathrm{W}$ of the Lomfjorden Fault (Bergh et al., 1994; Dallmann et al., 2009). The northern end of the reverse fault is truncated by the Geren 
433 Fault (Fig. 3). Its continuation to the $\mathrm{S}$ and its cutting relationship with the Lomfjorden Fault is 434 unclear, because it disappears under the icecap S of Løveryggen. The Bjørnfjellet Reverse Fault 435 carried red beds of the Neoproterozoic Veteranen Group sandstones eastwards on top of flat436 lying horizontal middle Carboniferous to Early Permian limestones and Early Cretaceous 437 dolerite sills (Figs. 3, 11A, and B) (Bergh et al., 1994). At Løveryggen, the reverse fault dips 438 about $45^{\circ}$ towards the W (Fig. 11B). In the footwall, the base of the Carboniferous can be 439 estimated at about 400 to $450 \mathrm{~m}$ a.s.l. underneath the ice of the glacier. In the hanging wall, the 440 Carboniferous is eroded above the $700 \mathrm{~m}$ high peak of Løveryggen. This relationship allows to 441 calculate a minimum displacement of $500 \mathrm{~m}$ towards the $\mathrm{E}$.

443 Interpretation. The transport of Neoproterozoic rock units on Carboniferous limstones and 444 Cretaceous sills towards the $\mathrm{E}$ along a W-dipping fault supports the orthogonal, convergent 445 character of the Bjørnfjellet Reverse Fault $\mathrm{S}$ of Lomfjordbotnen as suggested by Bergh et al. 446 (1994). Local minor structures are a few NW-SE striking $\mathrm{cm}$-scale shear planes with dextral 447 slickenside lineations and dextral faults with lateral offsets of the Neoproterozoic strata in the 448 range of a few $\mathrm{cm}$ (Fig. 11C).

Vinkelen Observations. The SW-facing $50 \mathrm{~m}$ high cliff of the nunatak Vinkelen NW of Chydeniusbreen 453 (Figs. 3 and 6) exposes a 100-meters-scale thrust ramp in middle Carboniferous to Early Permian 454 limestones and dolomites of the Gipsdalen Group (Fig. 12). Along the structure with its flat-ramp 455 geometry, folded and thrust-faulted sedimentary rocks were carried towards the NW on top of 456 unfolded limestones (Fig. 12). As the outcrop is inaccessible, bedding planes, faults and folds 457 could not been measured. The thrust ramp was estimated to dip towards $\mathrm{SE}$, and the $\mathrm{B}_{2}$-fold axes 458 were estimated to trend NE-SW. The thrust displacement is in the range of a few tens-of-meters, 459 assuming that the reddish weathering limestones in the footwall of the ramp and within the fold 460 in the hanging wall are correlated. The structure is local and could not be traced farther across 461 the glacier SW of Vinkelen. 
Interpretation. The estimated SE-dip of the thrust ramp and the NE-SW trend of the $\mathrm{F}_{2}$-folds

464 (Fig. 12) indicate approximately NW-SE shortening, oblique to the NNW-SSE striking faults in 465 the area, e.g., the Lomfjorden Fault farther to the SW (Fig. 3). This sense of obliquity is 466 compatible with an interpretation of sinistral kinematics in an overall N-S to NNW-SSE tectonic regime, provided the shortening at Vinkelen is related to strike-slip deformation.

\section{Raudberget}

Observations. Another local thrust is exposed in and restricted to the SW-cliff of Raudberget (Figs. 3, 6, and 13). There, steeply NE-dipping Neoproterozoic rocks of the Veteranen Group and unconformably overlying horizontal limestones of the Carboniferous Wordiekammen Formation are carried towards NW on top of steeply NW-dipping Carboniferous deposits. The thrust displacement is approximately $50 \mathrm{~m}$ (Fig. 13A). The folds related to the thrust are estimated to trend NE-SW, which is similar to the situation at Vinkelen (compare Fig. 12). In an outcrop near the upper edge of the cliff in the hanging wall of the thrust, the Carboniferous strata are folded around m-scale folds with NW-SE trending axes, which are perpendicular to the axes of the thrust-related folds (Fig. 13B). The tectonic transport direction of the SW-vergent fold is supported by a brittle, m-scale thrust with a flat-ramp geometry (Fig. 13B).

Interpretation. The deformation in the Neoproterozoic and Carboniferous rocks at Raudberget is characterized by two perpendicular, superimposed shortening phases with a NW-directed thrust ramp and SW-vergent folds. These shortening directions do not coincide with the E-W contraction across the Lomfjella and Bjørnfjellet reverse faults. In addition, regional tectonic events characterized by SE-NW and NE-SW shortening directions are unknown in East

487 Spitsbergen, and the thrust and folds at Raudberget represent local structures. On the other hand, 488 the oblique orientations of the two shortening directions with respect to the N-S striking master 489 faults of the Lomfjorden Fault Zone make it possible that the two deformation phases at 490 Raudberget were caused by strike-slip tectonics, similar to the interpreted situation at 491 Mjölnerfjellet (Fig. 8) and Vinkelen (Fig. 12). If so, the phase with oblique NE-SW shortening 492 can be related to an overall N-S trending dextral regime (Fig. 13D $)$, and the phase with SE-NW 493 shortening can be related to an overall N-S trending sinistral strike-slip regime (Fig. $\left.13 \mathrm{D}_{2}\right)$, 
494 provided the shortening at Raudberget is related to strike-slip deformation. As we could not find 495 cutting relationships between the structures of the two phases, the relative timing of the two 496 deformation phases remains unclear.

\section{Polarisbreen}

Observations. Between Chydenuisbreen and Ursafonna, the ENE-limb of the major Caledonian 501 Ursafonna Anticline exhibits km-thick deposits of the Neoproterozoic to Cambrian Lomfjorden 502 Supergroup (Figs. 3 and 6). The bedding planes of the different units strike NNW-SSE and dip 503 towards the ENE with mostly $30-45^{\circ}$ (Fig. 14A and B). The entire $\mathrm{F}_{1}$ fold limb of the anticline 504 is truncated by a number of NE-SW striking, subvertical faults parallel to the assumed fault 505 along the axis of Chydeniusbreen (Figs. 3 and 14A). Similar to the area at Geren, the faults exhibit dextral offsets of the sedimentary layers and the boundaries of the major rock units with magnitudes of up to some hundreds of m (Fig. 14A). The field observations are supported by interpretations of aerial photographs, which indicate that individual rock units are stepwise dextrally offset along the NE-SW striking faults, especially in the fault swarm on the nunatak Vettene S of Polarisbreen (Fig. 14A). At Dracofjella S of Dracoisen, a minor WNW-ESE striking fault indicates a sinistral offset of the strata of approximately $100 \mathrm{~m}$ (Fig. 14A).

At the northeastern part of the Grovtoppane mountain ridge SE of Chydenuisbreen (outcrops

514 A925 and A946; Figs. 3, 6, and 14A), ENE-dipping Neoproterozoic to Cambrian sedimentary

515 rocks display cm-scale shear planes with slickenside lineations that support the interpretation of 516 dextral displacement along the NE-SW striking faults (compare Fig. 14A and C). In addition, 517 NW-SE striking shear planes with sinistral slickenside lineations are exposed at outcrop scale 518 (Fig. 14C). Steeply SSE-dipping cm-scale shear planes with reverse slickenside lineations show 519 NNW-SSE shortening (Fig. 14C).

521 Interpretation. Owing to the difference in elevation of the Carboniferous unconformity on 522 opposite sides of the glacier valley between Grovtoppane and Cepheusfjellet (Fig. 14B) and the 523 truncation of the NE-SW striking faults in that valley, we have inferred the presence there of a 524 N-S striking fault, likely to be the northward continuation of the Agardhbukta Fault (Fig. 14A). 
525 The exposed NE-SW striking dextral strike-slip faults and shear planes are dominant between

526 Chydeniusbreen and around Dracoisen (Fig. 14A and C). As in the Geren and Freken area

527 (compare Fig. 9A), their cutting relationships to the northern segment of the Agardhbukta Fault

528 are unclear. However, they cannot be traced into the Carboniferous and Permian strata E of the

529 fault (Fig. 14A). Another subordinate set is represented by the small, WNW-ESE striking

530 sinistral fault at Dracofjella (Fig. 14B) and NW-SE striking sinistral shear planes (Fig. 14C).

531 Compared with the area at Geren, both sets can be interpreted as conjugate sets of sinistral and

532 dextral shear planes and faults, related to an overall E-W contraction (Fig. 14D). This is

533 supported by approximately E-W striking extension joints. The only set of shear planes, which

534 does not fit into this picture, is represented by steeply SSE-dipping shear planes with reverse

535 slickensides (Fig. 14C).

537 Oslobreen

539 The Oslobreen area is dominated by a number of NNW-SSE striking faults at Dolerittfjellet and 540 Sillhøgda and a segment of the N-S striking Agardhbukta Fault at Kirtonryggen (Figs. 3, 6, and 541 15B). As the nature of the relationship between the faults is obscured by the ice of Oslobreen 542 (Figs. 3 and 15B), it is not possible to see whether the NNW-SSE faults turn southwards into a 543 N-S direction and merge with the Agardhbukta Fault. In any case, the faults do not continue SE544 wards into either the area with horizontal Carboniferous and Permian successions at Rotfjellet 545 and Kassiopeiafjellet or the Paleozoic rocks at Kirtonryggen (Figs. 3 and 15B), indicating that 546 the NNW-SSE faults are limited to the E by the N-S striking Agardhbukta Fault.

548 Observations at Kirtonryggen. A key outcrop in this area is located SW of Kirtonryggen. There, 549 two N-S striking strands of the Agardhbukta Fault separate horizontal Carboniferous/Permian 550 strata and Cretaceous dolerite sills in the W from E-dipping Early Paleozoic rocks of the 551 Oslobreen Group in the E (outcrops A949-951; Fig. 15B). Between the two strands of the fault, 552 a local hundreds-of-meters-scale WNW-vergent $\mathrm{F}_{2}$-fold is developed in Carboniferous 553 limestones, with a moderately ESE-dipping long limb and an overturned, steeply ESE-dipping 554 short limb (Fig. 15C). ENE-dipping cm-scale shear planes with normal slickenside lineations and 
approximately $\mathrm{N}-\mathrm{S}$ striking shear planes with oblique sinistral slickenside lineations were also

556 observed in this area (Fig. 15D).

Interpretation. The WNW-ESE contraction in this outcrop is supported by the NNE-SSW orientation of the $\mathrm{B}_{2}$-fold axis, cm-scale shear planes with oblique, ESE-directed reverse slickenside lineations and by normal shear planes indicating an ENE-WSW extension direction (Fig. 15D). The oblique orientation of the local $F_{2}$-fold structure and the WNW-ESE shortening direction with respect to the two strands of the Agardhbukta Fault suggest that the deformation in this outcrop area can be related to sinistral strike-slip along the N-S striking Agardhbukta Fault imposing a transpressional stress regime on the block between the fault strands (compare Fig. $\left.16 \mathrm{D}_{3}\right)$. This is supported by a number of $\mathrm{cm}$-scale $\mathrm{N}-\mathrm{S}$ striking shear planes with oblique sinistral slickenside lineations (compare Figs. $15 \mathrm{D}$ and $16 \mathrm{D}_{3}$ ).

Observations at the Sillhøgda Fault. Northwest of Oslobreen, the NNW-SSE striking Sillhøgda Fault separates horizontal Carboniferous and Permian deposits with Early Cretaceous dolerite sills in the WSW from E-dipping Neoproterozoic rocks of the Akademikarbreen Group and the Cambrian Oslobreen Group in the ENE and unconformably overlying horizontal Carboniferous

572 (Fig. 15A and B). The fault dips steeply to the WSW and the stratigraphic offset across it 573 indicates a normal down-to-the-WSW sense of displacement. The bending of the horizontal 574 Carboniferous/Permian deposits across a monoclinal drag fold into a steeply WSW-dipping 575 position (Fig. 15A) supports this interpretation. Further NE, at the eastern end of Ditlovtoppen, another NNW-SSE striking fault is exposed (Fig. 15A and B). A normal down-to-the-ENE sense of displacement for this fault is confirmed by downthrow of the Carboniferous unconformity to 578 the ENE of about $100 \mathrm{~m}$ (Fig. 15A).

Observations at the Dolerittfjellet Reverse Fault. Subparallel to the Sillhøgda Fault (normal dipslip), the $45^{\circ} \mathrm{WSW}$-dipping Dolerittfjellet Reverse Fault (Figs. 15B and 16A) carries SSWdipping Neoproterozoic limestones over horizontal Carboniferous/Permian rocks and Early

583 Cretaceous dolerite sills (Figs. 15A and 16A) with a minimum displacement of $150 \mathrm{~m}$. Cm-scale

584 SW-dipping brittle shear planes with reverse slickenside lineations in the Neoproterozoic

585 limestones (Fig. 16B) support the ENE-WSW shortening across the reverse fault. 
587 In the southwestern hanging wall of the Dolerittfjellet Reverse Fault, SW-dipping rock units of the Neoproterozoic Polarisbeen and Akademikarbreen groups are locally truncated by ENEWSW striking faults with dextral offsets of the strata in the range of a hundred $\mathrm{m}$ (Fig. 15B). In addition, the limestones are cut by minor NE-SW striking shear planes with sinistral slickenside lineations (Fig. 16B). The Carboniferous deposits in the footwall display minor NE-SW and WNW-ESE striking shear planes with dextral and sinistral slickenside lineations, respectively 593 (Fig. 16C).

Interpretation. Mapping and structural observations indicate that the Dolerittfjellet Reverse 596 Fault is a result of ENE-WSW contraction. This is further supported by an ENE-WSW striking sinistral fault and a N-S striking dextral fault on the small, $780 \mathrm{~m}$ high, nunatak $\mathrm{N}$ of Dolerittfjellet (Fig. 15B), which can be interpreted as a conjugate set of faults related to the local ENE-WSW shortening across the reverse fault (Fig. 16D 1 ).

A correlation of the Bjørnfjellet Reverse Fault and Dolerittfjellet Reverse Fault is improbable,

602 because both faults are separated by $30 \mathrm{~km}$ of glaciers and have distinctly different orientations

603 (Fig. 3). The oblique NNW-SSE orientation of the Dolerittfjellet Reverse Fault with respect to

604 the N-S striking Lomfjorden and Agardhbukta faults suggests that this local reverse fault was the 605 result of strike-slip deformation. The ENE-WSW shortening direction coincides with a dextral 606 strike-slip system along the N-S striking major faults (Fig. $16 \mathrm{D}_{1}$ and $\mathrm{D}_{2}$ ).

However, the parallel orientation of the normal Sillhøgda Fault to the contractional Dolerittfjellet 609 Reverse Fault must be explained as well (Fig. 15B). If the Sillhøgda Fault also was caused by 610 strike-slip movements, the oblique ENE-WSW extension direction with respect to the master 611 faults is compatible with a N-S oriented sinistral strike-slip system $\left(\right.$ Fig. $\left.16 \mathrm{D}_{3}\right)$. This scenario is 612 supported by the tectonic fabric elements in the outcrop SW of Kirtonryggen, which show a 613 WNW-ESE shortening direction and an ENE-WSW extension direction as along the Sillhøgda 614 Fault (compare Figs. 15D and $16 \mathrm{D}_{3}$ ). Provided the shortening and extension directions in the 615 Oslobreen area are related to superimposed strike-slip deformation, then the Dolerittfjellet 616 Reverse Fault (ENE-WSW shortening; Fig. 16D ${ }_{1}$ and $\mathrm{D}_{2}$ ) was formed during dextral, 
617 transpressional and the Sillhøgda Fault and the deformation in the Carboniferous strata SW of 618 Kirtonryggen (WNW-ESE shortening; ENE-WSW extension; Figs. 15D and 16D 3 ) during 619 sinistral, transtensional strike-slip movements along the N-S striking Lomfjorden Fault Zone.

\section{$621 \quad$ Pachtusovfjellet}

623 Observations. At Pachtusovfjellet (Figs. 2B and 6B), Carboniferous and Permian deposits are 624 folded into a hundreds-of-meters-scale $\mathrm{F}_{2}$-flexure or monocline with a gently E-dipping to 625 horizontal eastern limb and a western limb dipping steeply towards the Agardhbukta Fault (Fig. 626 17A and B). This flexure runs parallel to the Agardhbukta Fault and re-occurs more than $20 \mathrm{~km}$ 627 farther S, E of Vivienberget (Fig. 6B). The Carboniferous and Permian deposits are affected by a 628 number of ENE- and steeply WSW-dipping cm-scale shear planes with reverse and sinistral 629 slickenside lineations (Fig. 17A). Similarly oriented cm-scale shear planes also show slickenside 630 lineations with normal senses of displacement. Additionally, some cm-scale NE-SW striking 631 shear planes are characterized by oblique dextral slickenside lineations.

633 Interpretation. The kinematics in this outcrop are dominated by orthogonal E-W shortening 634 across and by minor sinistral movements parallel to the Agardhbukta Fault. E-W contraction E 635 of the Agardhbukta Fault is supported by the hundreds-of-meters-scale, N-S trending flexure and 636 by ENE- and WSW-dipping shear planes with reverse slickenside lineations in the Carboniferous 637 strata (Fig. 17A and B). Some NE-SW striking dextral shear planes (Fig. 17A) could be either 638 interpreted as part of a conjugate set related to E-W shortening across or as synthetic shear 639 planes related to dextral strike-slip movements along the Agardhbukta Fault (Fig. 17D 1 ). In 640 addition, N-S striking shear planes with sinistral slickenside lineations are compatible with 641 sinistral displacements along the Agardhbukta Fault (Fig. 17A). One problem is that the shape of 642 the flexure with a western short limb indicates transport direction to the W (Fig. 17B). Usually, 643 the rock units in the footwall of a reverse fault are younger than the rocks in the hanging wall.

644 Here, the hanging wall consists of Carboniferous and the footwall of Neoproterozoic rocks. This 645 suggests that the Carboniferous and Permian strata were carried westwards across the 646 Agardhbukta Fault during a first phase of W-E contraction. Later, the Agardhbukta Fault was 647 reactivated as a normal fault downfaulting the Carboniferous/Permian strata in the E against the 
648 Neoproterozoic rocks in the W. This is supported by some E- and W-dipping shear planes with

649 extensional slickenside lineations can probably be related to a later extensional reactivation along 650 the Agardhbukta Fault (Fig. 17A). It is, however, not possible to determine the relative timing of 651 the strike-slip movements with respect to the phases of contraction and extension.

Vivienberget

Observations. The mountain Vivienberget (Figs. 2B and 6B) consists of Neoproterozoic rocks in the W, folded during the Caledonian Orogeny, and Early Permian deposits of the Gipshuken Formation in the E, separated by the Agardhbukta Fault (Fig. 2B). A ridge connecting the Permian and Neoproterozoic outcrops exhibits several subvertical fault strands parallel to the master fault, with slices of various, stratigraphically disturbed Neoproterozoic rock units in between. Exposure conditions do, however, not allow for detailed structural observations. The nunatakk Brekkeknausen between Vivienberget and Malte Brunfjellet shows an E-directed thrust and normal faults in the Neoproterozoic (Miloslavskij et al., 1996; Dallmann, 2015). Two moderately W-dipping, E-directed thrusts with transport directions towards the E are exposed in

664 Permian strata at Chimkovfjellet E of the Agardhbukta Fault NE of Vivienberget (Larsen, 1988;

665 Miloslavskij et al., 1996; Fig. 2B). This indicates that also this segment of the Lomfjorden Fault

666 Zone was affected by W-E contraction E of the Agardhbukta Fault. The well-exposed

667 Neoproterozoic units to the $\mathrm{W}$ of the fault zone are affected by cm-scale NNE-SSE striking

668 shear planes with dextral slickenside lineations, ESE-WNW striking shear planes with sinistral oblique slickenside lineations, and dm- to m-scale NE-directed reverse faults (Fig. 17C).

Interpretation. The NNE-SSW striking brittle shear planes with dextral displacements, SW-

672 dipping reverse faults, and NE-dipping shear planes with reverse slickenside lineations (Fig.

673 17C) are compatible with an overall NNE-SSW dextral strike-slip regime with an approximately 674 NE-SW shortening direction (Fig. $17 \mathrm{D}_{2}$ ). Because the tectonic fabric elements have only been 675 observed in Neoproterozoic rocks, a precise timing of the deformation is difficult. However, the

676 brittle character and the orientation of the dextral shear planes parallel to the nearby Agardhbukta 677 Fault in the E indicate that a post-Carboniferous deformation along the Agardhbukta Fault is also 678 possible. 


\section{Malte Brunfjellet}

682 Observations. Malte Brunfjellet is a nunatak directly W of the Agardhbukta Fault, NE of 683 Tempelfjorden (Figs. 2B and 6B). There, Neoproterozoic deposits (Polarisbreen Group) are unconformably overlain by horizontal Carboniferous strata. As can be seen by the stratigraphy in adjacent nunataks, the eastern side of the fault has apparently dropped by at least $200 \mathrm{~m}$

686 (Miloslavskij et al., 1996). The analyses of shear planes, faults, and slickenside lineations show a complex distribution and orientation of the structures indicating a superposition of various tectonic events (Fig. 18A and B). The Carboniferous and Early Permian strata are cut by a number of dm- to m-scale, steeply NW-dipping reverse faults (Fig. 18B). An irregular set of cmscale shear planes with reverse slickenside lineations show transport directions ranging from towards the NNE (Fig. 18A), across N, to NW (Fig. 18B). Extensional kinematics are indicated by NE-SW (Fig. 18A) and NNW-SSE striking (Fig. 18B) cm-scale shear planes with normal slickenside lineations and extension joints. Lateral displacements are indicated by $\mathrm{cm}$-scale fault planes with E-W trending sinistral and NW-SE trending dextral (Fig. 18A), and NNE-SSW trending dextral and sinistral slickenside lineations (Fig. 18A and B).

Interpretation. The Carboniferous/Permian sedimentary rocks at Malte Brunfjellet are affected by post-Carboniferous deformation and comprise a number of faults, shear planes, and extension joints with heterogeneous kinematic indications (Fig. 18A and B). This nonuniform distribution can only be explained by the superposition of different tectonic events with different kinematics. A post-Caledonian E-W shortening scenario in the Carboniferous to Permian rock units at Malte Brunfjellet can be excluded: corresponding tectonic elements like W- or E-directed reverse faults and a conjugate set of NW-SE striking sinistral and NE-SW striking dextral faults and shear planes are not developed here (compare Fig. 18A, B, and $\mathrm{C}_{1}$ ). The different faults, shear planes and extension joints at Malte Brunfjellet can be explained by lateral movements along the nearby Agardhbukta Fault: 
710 trending sinistral regime; (b) NNE-SSW striking shear planes with sinistral slickenside

711 lineations (Fig. 18B) compatible with being secondary synthetic shears; (c) NNW-SSE striking

712 extension joints and shear planes with normal slickenside lineations showing an ENE-WSW

713 extension direction (Fig. 18B); (d) steeply NW-dipping reverse faults and SE-dipping shear

714 planes with reverse slickenside lineations in the Carboniferous/Permian rocks indicating a NW-

715 SE orientation of the shortening direction (Fig. 18B).

717 A dextral N-S strike-slip scenario (Fig. 18A and $\mathrm{C}_{3}$ ) is supported by: (a) NNE-SSW striking

718 dextral faults and shear planes compatible with being synthetic structures in a N-S striking

719 dextral regime (Fig. 18A); (b) local NW-SE striking dextral shear planes, which are compatible

720 with being secondary synthetic shears (Fig. 18A); (c) E-W striking shear planes with sinistral

721 slickenside lineations (Fig. 18A); (d) NE-SW striking extension joints indicating a NW-SE

722 extension direction (Fig. 18A); (e) steeply SSW-dipping shear planes with reverse slickenside

723 lineations (Fig. 18A) compatible with a N-S striking dextral regime (Fig. 18C 2 ). These

724 interpretations support the assumption that the Carboniferous/Permian rocks at Malte Brunfjellet

725 were affected by superimposed sinistral and dextral movements along a N-S striking master

726 fault, although the relative succession of the two phases cannot be determined based on the

727 observed structures.

\section{DISCUSSION}

\section{Deformational phases and timing}

734 Structural fieldwork in the exposed outcrops along the faults has shown that the Neoproterozoic-

735 Permian sedimentary rocks and the Early Cretaceous dolerite intrusions were affected by

736 convergent tectonic movements. On the other hand, the appearance of many heterogeneous and

737 overlapping structures and tectonic fabric elements with different orientations and kinematics in

738 a number of observed outcrops suggests that the deformations along the Lomfjorden Fault Zone

739 cannot be only related to a single W-E contraction but to a succession of tectonic phases, which

740 were also controlled by lateral movements. 
$742 N-S$ striking reverse faults. Convergent kinematics across the Lomfjorden Fault Zone are 743 clearly documented by the steep N-S striking Lomfjella and Bjørnfjellet reverse faults between

744 the Veteranen and Lomfjorden faults in the northern segment (Figs. 3, 10, and 11). In the central

745 segment, the $40 \mathrm{~km}$ long flexure in Carboniferous to Permian deposits E of the Agardhbukta

746 Fault can be correlated to the same E-W shortening event (Fig. 17). Another convergent

747 structure is the Dolerittfjellet Reverse Fault in the Oslobreen area, however, due to its isolated

748 occurrence and different orientation, a correlation with the $\mathrm{N}-\mathrm{S}$ striking reverse faults in the

749 Lomfjorden area and at Agardhbukta is not considered.

The Lomfjella und Bjørnfjellet reverse faults have affected early Carboniferous to early Permian

752 deposits and can be separated from Caledonian thrusts in Neoproterozoic rocks. More important

753 is that both reverse faults have also carried Neoproterozoic rocks over dolerite sills at Lomfjella,

754 Bjørnfjellet and Løveryggen, which indicates that the E-W shortening along the reverse faults

755 took place after the intrusion of the dolerite sills from ca. 125-78 Ma ago (Corfu et al., 2013;

756 Senger et al., 2014). The long flexure E of the Agardhbukta Fault in the central segment, for

757 instance observed at Pachtusovfjellet, has involved Carboniferous and Permian rocks and can be

758 correlated with the post-Early Cretaceous Lomfjella and Bjørnfjellet reverse faults. Apart from

759 the clearly convergent structures along the Lomfjella and Bjørnfjellet reverse faults and the

760 flexure at Pachtusovfjellet, we have not found clear evidence for W-E shortening in the observed

761 outcrops along the Veteranen, Lomfjorden and Agardhbukta faults, like E- or W-dipping faults

762 or shear planes with reverse slickensides, except for the outcrops at Geren (Fig. 9B).

NE-SW striking dextral faults. As clear cutting relations to the $\mathrm{N}-\mathrm{S}$ major faults are not exposed and always covered by scree or glacier ice, it is difficult to interpret the affiliation of the NE-SW striking dextral faults to other structures along the Lomfjorden Fault Zone. There are

767 three possible tectonic explanations:

769 (a) One distinctive feature is the observation that the NE-SW faults have not affected the 770 Carboniferous and younger rocks in the study area (compare Fig. 3). This could be an argument 771 for a pre-Carboniferous age of these faults. The Caledonian deformation in this area is dominated 
772 by km-scale, N-S trending folds (Fig. 5) and E- and W-dipping reverse faults. On this account,

773 the dextral NE-SW faults can represent one part of a conjugate set related to Caledonian E-W

774 contraction. On the other hand, it is also obvious that these faults are not developed in the

775 basement areas W of the Veteranen Fault and the southern part of the Lomfjorden Fault (Fig. 3).

776 In addition, the E-W faults cut through and displace the Lomfjella and Bjørnfjellet reverse faults,

777 which themselves have affected Carboniferous and younger rocks. This makes a pre-

778 Carboniferous age of the NE-SW faults improbable.

(b) The NE-SW striking dextral faults can also be interpreted as a part of a conjugate set of faults that accommodated the last gasp of shortening during the formation of the Lomfjella and

782 Bjørnfjellet reverse faults (compare Fig. 10D). It is conspicuous that there is no or little sinistral 783 equivalent of this conjugate set, except for a small sinistral WNW-ESE fault at Dracoisen (Fig.

784 14A) and outcrop-scale sinistral shear planes with a similar orientation (Figs. 8A, B, 14C, and

785 16C). If the dextral NE-SW faults can be attributed to the W-E shortening between the

786 Veteranen and Lomfjorden faults, they also post-date the intrusion of the dolerite sills and do not

787 represent Caledonian structures. In this case, they should also have affected the basement areas

788 W of the Veteranen Fault and the Carboniferous and younger rocks E of the Lomfjorden Fault, 789 either cutting through or being offset by them.

(c) Another possibility is that the NE-SW striking dextral faults are related to strike-slip

792 movements along the major faults of the Lomfjorden Fault Zone. Although it cannot be seen in

793 the field whether the dextral faults are truncated by the N-S master faults or if they merge with

794 them, it is obvious that they are limited to the areas between the Veteranen, Lomfjorden and

795 Agardhbukta faults (Fig. 3). It is, therefore, possible that they can also represent synthetic dextral

796 faults within a large-scale dextral strike-slip regime along the N-S Lomfjorden Fault Zone. In

797 summary, a final conclusion on the origin and tectonic reason of the NE-SW striking dextral

798 faults cannot be suggested here and needs more field data. 
803 fjords and glaciers, and outcrops are rare. In addition, often nonuniform and irregular

804 orientations and relationships of tectonic fabric elements and their kinematic evidence in the

805 limited number of accessible outcrops make it difficult to gain clear and direct indication and

806 evidence for strike-slip movements along the N-S striking faults of the Lomfjorden Fault Zone.

807 The structural observations in the outcrop areas have shown that the rock units in many outcrops

808 are characterized by NE-SW and NW-SE oriented shortening and extension directions,

809 respectively, and are often combined with lateral faults and shear planes, which, altogether, do

810 not coincide with the W-E shortening across the Lomfjella and Bjørnfjellet reverse faults

811 discussed above. The structural diversity found in these outcrops can be explained as a

812 consequence of local strain produced by strike-slip movements along the Lomfjorden and

813 Agardhbukta faults. Assuming that the N-S striking major faults represent the actual zones of

814 tectonic movements and displacements, the oblique orientations of local convergent or

815 extensional structures with respect to the major faults are important for the interpretation of

816 possible strike-slip movements.

818 The best exposure with the most reliable indications for strike-slip movements along the N-S

819 striking major faults can be found along the Agardhbukta Fault at Kirtonryggen. There, a

820 hundred $\mathrm{m}$ scale, NNE-SSW trending $\mathrm{F}_{2}$-fold in Carboniferous strata is pinched between the two

821 strands of the superior N-S fault. The fold-structure with WNW-ESE shortening and ENE-

822 WSW extension directions is most likely related to sinistral movements along the Agardhbukta

823 Fault (compare Figs. 15D and $16 \mathrm{D}_{3}$ ). This is supported by $\mathrm{N}-\mathrm{S}$ striking shear planes with

824 sinistral slickenside lineations (Fig. 15D). Another outcrop with a thrust in Carboniferous

825 limestones at Vinkelen depicts a similar NW-SE shortening direction (Fig. 12), which also may

826 indicate a sinistral scenario parallel to the N-S master faults. At Pachtusovfjellet, sinistral

827 movements along the nearby Agardhbukta Fault are directly observed by some shear planes with

828 sinistral slickenside lineations (Fig. 17A). In another case, the oblique orientation of the NNE-

829 SSW shortening orientation in Carboniferous limestones at Mjølnerfjellet is compatible with

830 dextral strike-slip motions along the Lomfjorden Fault. This supposition is supported by NNE-

831 SSW striking dextral and WNW-ESE striking sinistral faults and shear planes, which can be

832 interpreted as synthetic and antithetic shears, respectively, in a N-S oriented dextral strike-slip

833 regime (Fig. 8A, B, and $\left.\mathrm{D}_{1}\right)$. 
835 There are two outcrop areas, which are more complex and characterized by a superposition of

836 perpendicular, NW-SE and NE-SW oriented shortening directions. At Raudberget, thrusting and

837 folding displays NW-SE and NE-SW shortening directions in Neoproterozoic and

838 Carboniferous rocks (Fig. 13) indicating possible local sinistral and dextal strike-slip

839 deformation within a N-S trending system. A similar situation is shown by shear planes with

840 sinistral, dextral and reverse slickenside lineations and extension joints at Malte Brunfjellet (Fig.

841 18). The distribution of the tectonic fabric elements depicting NE-SW and NW-SE shortening

842 directions and NW-SE and ENE-WSW extension directions can be explained by a superposition

843 of dextral and sinistral strike-slip movements, respectively, along the Agardhbukta Fault.

845 In the above mentioned outcrops, Neoproterozoic and Carboniferous to Permian sedimentary 846 rocks are affected by NE-SW and NW-SE shortening and extension and combined systems of 847 strike-slip faults and shear planes indicting that the deformations took place after the Permian.

848 Additionally, outcrops in Neoproterozoic sedimentary rocks are interpreted to be affected by 849 NNE-SSW striking sinistral strike-slip movement at Kapp Fanshawe (Fig. 7) and by dextral 850 movements along the Agardhbukta Fault at Vivienberget (Fig. 17C) and at Geren and Freken 851 (Fig. 9B). Because the tectonic fabric elements in these outcrops have only affected 852 Neoproterozoic rocks, a more precise timing is not possible. However, the similarity to the 853 structures described above and the close location to the Lomfjorden Fault and Agardhbukta 854 Fault, respectively, make it possible that the deformation in these outcrops is also related to post855 Permian strike-slip deformations.

857 Sillhøgda Fault and Dolerittfjellet Reverse Fault. Between Balderfonna and Andromedafjellet, 858 the NNW-SSE striking Dolerittfjellet Reverse Fault and the parallel, normal Sillhøgda Fault are 859 obliquely oriented with respect to the master N-S faults. In this context, the en-échelon 860 arrangement of the two major faults is an important observation: the Lomfjorden Fault can be 861 traced from Kapp Fanshawe in the $\mathrm{N}$ to the highly glaciated areas around the Newtontoppen 862 Granite in the S, whereas the Agardhbukta Fault starts under the ice of Balderfonna in the $\mathrm{N}$ and 863 can be traced towards Agardhbukta in the S (Figs. 2B, 3, and 19) indicating a left-stepping 864 arrangement of the two faults (Fig. 19). The kinematics and geometries of fault orientations in 
865 the overlap area suggest that this area underwent strike-slip deformation characterized by zones

866 of contraction and extension in the overlap area between the overstepping Lomfjorden and

867 Agardhbukta faults (Fig. 19). In this scenario, two possible strike-slip scenarios are possible:

869 (a) The Dolerittfjellet Reverse Fault can be related to a left-stepping contractional overstep or to

870 left-stepping wrench faults with NNW-SSE striking reverse faults in the overstep zone (McClay,

871 1987; Fig. 19A 1 ) or dextral restraining offsets (Woodcock and Fischer, 1986; Fig. 19A). This

872 situation is comparable with the local NE-SW shortening directions in Carboniferous and

873 younger rocks at Mjølnerfjellet, Raudberget, Malte Brunfjellet, and in Neoproterozoic rocks at

874 Vivienberget (Fig. 19A). These geometries are compatible with a N-S trending dextral strike-slip 875 deformation.

877 (b) The Sillhøgda Fault and parallel oriented normal faults can be related to a left-stepping 878 extensional overstep or to left-stepping wrench faults with NNW-SSE striking extensional faults 879 in the overstep zone (McClay, 1987; Fig. 19B ) $_{\text {) }}$ or sinistral releasing offsets (Woodcock and 880 Fischer, 1986; Fig. 19B). This situation is comparable with the local NE-SW extension 881 directions in Carboniferous and younger rocks at Kirtonryggen and Malte Brunfjellet and is 882 supported by NW-SE oriented shortening directions in Carboniferous and younger rocks at 883 Vinkelen, Raudberget, Kirtonryggen and Malte Brunfjellet (Fig. 19B). These geometries are 884 compatible with a N-S trending sinistral strike-slip deformation.

It should be noted that the large intrusion of the Newtontoppen Granite is situated just SW of the 887 overlap area between the Lomfjorden and Agardhbukta faults (Fig. 19). The intrusive body has 888 most probably acted as a buttress during strike-slip deformation and is responsible for the en889 échelon offset between the two major faults and the location of the releasing and restraining 890 offsets in the overlap area. Teben'kov et al. (1996) described the Newtontoppen Granite as an 891 asymmetric lopolith or harpolith-like body with a steep root in its southwestern part and 892 extended elongations towards the $\mathrm{N}$ and $\mathrm{E}$. This may be a reason that strike-slip along the 893 Lomfjorden fault could not penetrate through the granite at its western side. 
895 From the cutting relations described above, the following relative succession of post-Early

896 Cretaceous tectonic phases along the northern and central segments of the Lomfjorden Fault

897 Zone can be expected:

(1) The older deformation phase 1 is characterized by the N-S striking contractional structures.

900 Between the Veteranen and Lomfjorden faults in the northern segment, the steep Lomfjella and

901 Bjørnfjellet reverse faults are characterized by W-E shortening (Figs. 3 and 19A). In the central

902 segment, the $40 \mathrm{~km}$ long flexure in Carboniferous to Permian deposits E of the Agardhbukta

903 Fault indicates that this section of the fault was also affected by E-W shortening (Fig. 19A).

905 (2) The second phase of deformation is characterized by strike-slip deformation along the major

906 N-S striking faults characterized by opposing NE-SW and NW-SE shortening and extension

907 directions in local outcrops and by left-stepping contractional and extensional oversteps in the

908 transfer area between the en-échelon Lomfjorden and Agardhbukta faults at a larger scale. It was

909 not possible in the field to determine a relative timing of the dextral and sinistral phases of lateral

910 motions, respectively, because we could not find clear cutting relationships of structures of the

911 two phases.

912

913 The significance of the N-S trending strike-slip movements along the Lomfjorden Fault Zone

914 cannot be estimated because the large-scale, $\mathrm{N}-\mathrm{S}$ striking master faults are oriented almost

915 parallel to the orientation of the Neoproterozoic rock units and the km-scale Caledonian $\mathrm{F}_{1}$-folds,

916 and the Carboniferous sedimentary rocks are always sub-horizontal, except for some folded areas

917 in the vicinity of the faults. Therefore, it is not possible to calculate or establish any amounts of

918 lateral displacements along the northern and central segments of the Lomfjorden Fault Zone.

920 Extensional structures. Apart from convergent and lateral structures along the Lomfjorden Fault

921 Zone, there is also evidence for normal faulting. The profile in Figure 4B shows that the

922 Carboniferous and younger sedimentary cover is already eroded and removed in the high

923 mountain areas W of the Lomfjorden Fault. East of it, the Carboniferous unconformity is located

924 below sea level or a little bit higher. Along the Lomfjorden Fault Zone, the following down-to-

925 east offsets can be estimated: In the northern segment, the downthrow across the Lomfjorden 
926 Fault exceeds $600 \mathrm{~m}$ between Lomfjella and Lomfjordhalvøya (Fig. 4A) and about 900m

927 between Jakobitoppen and Klumpen (Fig. 4B). Farther E, the downthrow across the Agardhbukta

928 Fault between Raudberget and Mertonryggen is at least $600 \mathrm{~m}$ (Fig. 4B). This is a difference of

929 more than 1,500 m between the high mountains $\mathrm{W}$ of Chydeniusbreen and the E-coast of

930 Lomfjordhalvøya across the entire fault zone. In the central segment, downthrows of 500-600 m

931 can be estimated between Golitsynfjellet and Pachtusovfjellet and at Vivienberget (Fig. 6B). In

932 the southern segment, Miloslavskij et al. (1993b) have estimated amounts of normal

933 displacements from 400-450 $\mathrm{m}$ at Eistraryggen $\mathrm{N}$ of Agardhdalen decreasing to $100 \mathrm{~m}$ at

934 Rurikfjellet S of Agardhdalen. The timing of the extensional movements remains difficult.

935 Apatite fission track analyses by Dörr et al. (2012) suggested that post-Early Jurassic uplift led to

936 removal of the Triassic, Jurassic and possibly younger sequences in the study area by erosion,

937 and the exhumation of the Newtontoppen Granite took place in latest Cretaceous to Paleocene

938 times. It is also possible, that vertical movements, apart from the W-E contraction along the

939 Lomfjella and Bjørnfjellet reverse faults, were caused by oblique lateral movements, or by young

940 extension following the strike-slip movements along the Lomfjorden Fault Zone.

942 Lateral variation in the Lomfjorden Fault Zone

944 South of Malte Brunfjellet, the southern section of the Agardhbukta Fault runs through Mesozoic

945 sedimentary rocks and has affected Triassic and Jurassic strata (Miloslavskij et al., 1993a, b; Fig.

946 2B). North and S of Agardhdalen, the exposed fault zone constitutes a single, asymmetric E-

947 facing, disrupted anticline in Mesozoic and probably Permian rocks (Kellogg, 1975; Andresen et

948 al., 1988, 1992, 1994; Larsen, 1988; Nøttvedt et al., 1988; Haremo and Andresen, 1992;

949 Miloslavskij et al., 1993a, b; Figs. 2B and 20). The deformation between the Billefjorden and

950 Lomfjorden fault zones is characterized by a combination of thin-skinned and thick-skinned

951 tectonics. Both the Billefjorden and Lomfjorden fault zones are pre-existing, steep, E- and W-

952 dipping, respectively, basement-involved faults, which were reactivated during the Paleogene

953 contraction causing inversion and uplift of the Ny-Friesland Block between the two fault zones

954 (e.g., Nøttvedt et al., 1988; Haremo and Andresen, 1992; Fig. 20). 
956 Although the southern segment of the Lomfjorden Fault Zone seems to be dominated by E-W

957 shortening, the geological map (Miloslavskij et al., 1993a) shows a number of faults,

958 monoclines, and anticline-syncline pairs approaching the main fault zone near Agardhdalen at

959 acute angles from the NE (Fig. 2B). These oblique, amalgamating orientations with respect to the

960 main fault, which are typical structures in strike-slip zones, indicate that lateral displacements

961 may have affected the Lomfjorden Fault Zone also in its southernmost segment. The oblique

962 orientations of the syncline and anticline axes with respect to the Agardhbukta Fault in this area

963 (Miloslavskij et al., 1993a, b) are compatible with sinistral displacements along the Agardhbukta

964 Fault and possibly the Storfjorden Fault in the E (Fig. 2B).

966 In contrast to the southernmost segment, the Lomfjorden Fault Zone N of Malte Brunfjellet (Fig.

967 2B) has affected Neoproterozoic and Paleozoic, but no Mesozoic rock units, except for the Early

968 Cretaceous dolerite sills (Figs. 2B and 3). While the southernmost segment is dominated by

969 contractional movements along detachment zones and thrusts, but only little strike-slip

970 components (see citations above), the northern and central segments are characterized by both E-

971 W shortening along steep reverse faults during a first and by strike-slip movements during a

972 second tectonic phase.

973

974 The apparent structural difference between the northern/central and southernmost segments of

975 the Lomfjorden Fault Zone can be explained by the different levels of exposure. Andresen et al.

976 (1988, 1992), Nøttvedt et al. (1988) and Miloslavskij et al. (1993b) suggested that the

977 contractional deformation at Agardhbukta was caused by a steep, pre-existing fault in the

978 Neoproterozoic basement underneath the Mesozoic and upper Paleozoic sedimentary succession

979 (Fig. 20). Possible candidates for such basement-rooted faults are exposed in the northern

980 (Lomfjella and Bjørnfjellet reverse faults) and in the central segment of the fault zone (flexure E

981 of the Agardhbukta Fault). These observations in combination with the results presented here

982 suggest that the northern segment of the Lomfjorden Fault Zone represents the basement

983 involved deeper level of the fault zone, which is covered by a Mesozoic succession in the S. It

984 should be noted that the assumed steep faults in the southern segment and the steep reverse faults

985 in the northern segment represent pre-existing, probably Carboniferous (and maybe older) faults,

986 which have been reactivated during the E-W shortening after the intrusion of the Early 
987 Cretaceous dolerite sills along the entire Lomfjorden Fault Zone, as suggested by Bergh et al. 988 (1994).

Relationship of the Lomfjorden Fault Zone to the West Spitsbergen Fold-and-Thrust Belt

992 The relationship between the West Spitsbergen Fold-and-Thrust Belt and the Lomfjorden Fault 993 Zone at Agardhdalen in the $\mathrm{E}$ is documented by the detachment zones in Triassic and Jurassic 994 strata underneath the Central Tertiary Basin (Fig. 20). The observed deformation along the 995 Lomfjorden Fault Zone was transferred from the W-coast of Spitsbergen eastwards along at least 996 three detachment zones localized in Permian gypsum and middle Triassic and late Jurassic 997 organic-rich shales (Andresen et al., 1988, 1992, 1994; Nøttvedt et al., 1988; Haremo and 998 Andresen, 1992; Braathen et al., 1995; Bergh et al., 1997; Blinova et al., 2012, 2013; Fig. 20). 999 The sedimentary successions hosting the three detachment zones in the southern segment of the

1000 Lomfjorden Fault Zone are already eroded and removed in the northern and central segments.

1001 This suggests that a much deeper detachment horizon is required for the contraction in the

1002 northern and central segments of the fault zone, that generated or reactivated reverse faults in the

1003 Neoproterozoic rocks in the N, but also the assumed basement-rooted faults in the S. A possible 1004 candidate is an Ellesmerian/Svalbardian detachment assumed in the pre-Devonian basement 1005 underneath the deformed Old Red Sandstone basin by Piepjohn $(1994,2000)$ and Piepjohn et al. 1006 (2015). Similar sub-Ellesmerian detachments are known from North Greenland and Ellesmere 1007 Island (Soper and Higgins, 1987; Klaper, 1990; Piepjohn et al., 2008; Piepjohn and von Gosen, 1008 2017; Stephenson et al., 2017). On Ellesmere Island, they were reactivated during the Paleogene 1009 Eurekan Orogeny (Harrison, 2008; Piepjohn et al., 2008; Piepjohn and von Gosen, 2017). It is 1010 possible that such an Ellesmerian deep-seated detachment on Spitsbergen was reactivated during 1011 the Eurekan convergent movements and responsible for the convergence across the post-Early

1012 Cretaceous reverse faults between the Veteranen and Lomfjorden faults in the northern segment. 1013

1014 This model may explain the differences between the northern/central and southernmost 1015 segments: the Mesozoic cover rocks including the convergent Eurekan detachment zones are 1016 located in a crustal level that is already eroded in the northern segment. The Lomfjella and 1017 Bjørnfjellet reverse faults in the northern segment can possibly be related to the same orthogonal 
1018 convergence. As the detachment zones are related to the formation of the West Spitsbergen Fold1019 and-Thrust Belt, the age of the post-Early Cretaceous deformation phases in the northern and 1020 central segments can be estimated as follows: The age of the West Spitsbergen Fold-and-Thrust 1021 Belt is estimated to be Paleogene by most authors (e.g., Kellogg, 1975; Andresen et al., 1988, 1022 1992; Larsen, 1988; Nøttvedt et al., 1988; Maher et al., 1989; Gion et al., 2017). K-Ar whole 1023 rock ages of $49 \mathrm{Ma}$ in ductilely deformed Carboniferous sediments at the E-coast of 1024 Forlandsundet Graben (Tessensohn et al., 2001) and ${ }^{40} \mathrm{Ar} /{ }^{39} \mathrm{Ar}$ muscovite ages of 55-44 Ma in 1025 the basement rocks of Prins Karls Forland (Faehnrich et al., 2017; Schneider et al., this volume, 1026 chapter 8) indicate that the culmination of the Eurekan Orogeny took place in the early Eocene. 1027 This is supported by Kleinspehn and Teyssier (2016), Piepjohn et al. (2016), and Barnes and 1028 Schneider (this volume, chapter 7) who suggest a structural change from convergent tectonics 1029 during a first phase (53-47 Ma) to strike-slip tectonics during a second stage (47-34 Ma) of the 1030 Eurekan Orogeny. The convergent E-W contraction was transferred to the E durng the first 1031 Eurekan phase (re-)activating the steep reverse faults along the Lomfjorden Fault Zone.

1032 Therefore, an Early Eocene age for the E-W shortening across the Lomfjella and Bjørnfjellet 1033 reverse faults in the northern and across the Agardhbukta Fault in the central and southern 1034 segments of the Lomfjorden Fault can be inferred, as supported by Bergh et al. (1994). The 1035 strike-slip movements along the Lomfjorden Fault Zone post-date the E-W contraction and can 1036 be therefore correlated with the second Eurekan phase of strike-slip faulting at the W-coast of 1037 Spitsbergen in the Late Eocene.

\section{The Lomfjorden Fault Zone within the Arctic framework}

1041 The formation of the West Spitsbergen Fold-and-Thrust Belt and the dextral translation along 1042 and parallel to the Hornsund Fault Complex at the W-coast of Spitsbergen (Riis \& Vollset, 1988;

1043 Sigmond, 2002; Dallmann, 2015) (including the Lomfjorden Fault Zone; Fig. 21) is closely 1044 connected with the Paleocene/Eocene plate-tectonic reconfiguration during the opening of the 1045 Eurasian Basin, Labrador Sea/Baffin Bay, and the North Atlantic Ocean (e.g., Talwani and 1046 Eldholm, 1977; Srivastava, 1978, 1985; Vink, 1982; Srivastava and Tapscott, 1986; De Paor et 1047 al., 1989; Tessensohn and Piepjohn, 2000; Gaina et al., 2009; Faleide et al., 2010; Tsikalas et al., 1048 2012; Døssing et al., 2013; Dallmann, 2015; Doré et al., 2016; Piepjohn et al., 2015, 2016; Gion 
1049 et al., 2017; Sømme et al., 2018). The orientation parallel to the continental margin of Svalbard 1050 and the succession of tectonic structural events indicate that the Lomfjorden Fault Zone, together 1051 with the Billefjorden Fault Zone and possibly the Svartfjella-Eidembukta-Daudmannsodden 1052 Lineament at the W-coast of Spitsbergen (Maher et al., 1997), represent major structural 1053 elements of the Eurekan Orogeny and the resulting movements between Greenland and Svalbard 1054 during the final separation of North America and Eurasia. In this context it should be noted that 1055 many faults in the Eurekan deformation zones on Ellesmere Island are characterized by two or 1056 multiphase, often staggered opposing sinistral and dextral strike-slip regimes (Fig. 21). On 1057 Ellesmere Island, sinistral strike-slip movements along the Wegener Fault were followed by 1058 contraction or oblique-sinistral movements along the Wegener Fault (Piepjohn et al., 2000b, 1059 2013, 2016; Saalmann et al., 2005, 2008; Tessensohn et al., 2008; von Gosen et al., 2008, 2012, 1060 this volume, chapter 18; Fig. 21). The fault zones parallel to the continental margin of North 1061 America (e.g., Mount Rawlinson Fault, Feilden Fault Zone) are characterized by both dextral and 1062 sinistral strike-slip movements (Piepjohn et al., 2013; Fig. 21). In Svalbard NE of the Hornsund 1063 Fault Complex, orthogonal contraction and formation of the West Spitsbergen Fold-and-Thrust 1064 Belt was followed by dextral strike-slip tectonics (CASE Team, 2001; Piepjohn et al., 2015, 1065 2016; Kleinspehn and Teyssier, 2016; Barnes and Schneider, this volume, chapter 7). The 1066 structural development along Lomfjorden Fault Zone shows a similar structural development 1067 with W-E contraction in an early deformation phase (possibly associated with the Eurekan stage 10681 by Piepjohn et al., 2016) and a later phase of dextral and sinistral strike-slip deformation, 1069 possibly associated with the Eurekan stages 1 and 2 by Piepjohn et al. (2016), respectively. 1070

1071 It remains unclear how the sinistral strike-slip movements in the northern/central segment of the 1072 Lomfjorden Fault Zone developed in the general dextral plate-tectonic setting between Northeast 1073 Greenland and Svalbard (see Fig. 21). But it should be noted that Ohta (1988), Maher et al.

1074 (1997), and Bergh et al. (2000) also assumed or observed sinistral strike-slip displacement at the 1075 NE-margin of Forlandsundet along the Svartfjella-Eidembukta-Daudmansodden lineament 1076 (SEDL; Fig. 2A). Maher et al. (1997) and Bergh et al. (2000) suggested two basic possibilities:

1077 (a) the sinistral motion is a local phenomenon in an overall dextral transpressive setting or (b) the 1078 sinistral motion reflects a short period of sinistral motion between Greenland and Svalbard 1079 (Barents Shelf) as proposed by Skilbrei and Srivastava (1993). 
1081 It is not possible to determine amounts of lateral dispacements long the Lomfjorden Fault Zone, 1082 because the faults are located almost parallel to the pre-Carboniferous Caledonian sturctures in 1083 the Neoproterotzoic rocks and the strike-slip faults cut through horizontal Carboniferous and 1084 younger rocks. This is similar to many other Eurekan strike-slip fault zones on Ellesmere Island, 1085 where the structural trends of the Ellesmerian and Eurekan deformations are more or less 1086 parallel, and often, structures of the Ellesmerian orogeny are affected or reactivated by Eurekan 1087 deformation (e.g., Piepjohn et al., 2008, 2015). It is also characteristic that the Carboniferous 1088 faults, which were generated during the formation of the St. Jonsfjorden, Billefjorden and 1089 Lomfjorden basins, were reactivated during the contractional and lateral movements of the 1090 Eurekan deformation: similar to the Lomfjorden Fault Zones, Early Carboniferous fault zones 1091 have been reactivated in North Greenland (Depot Bugt Conglomerate; Piepjohn and von Gosen, 1092 2001) and on Ellesmere Island (“Okse Bay Group”; Beauchamp et al., this volume, chapter 13). 1093 The locations of Paleogene Eurekan contractional and lateral faults paralleling the continental 1094 margins of Barents Shelf and North America were controlled by the pre-existing zones of crustal 1095 weakness from Carboniferous or even older tectonic events.

\section{CONCLUSIONS}

1100 The N-S striking Lomfjorden Fault Zone in eastern Spitsbergen consists of three master faults, 1101 the Veteranen, Lomfjorden, and Agardhbukta faults, which are linked up by a complex network 1102 of NE-SW and NW-SE striking strike-slip, reverse and normal faults. The fault zone cuts 1103 through Neoproterozoic, Carboniferous, and Permian sedimentary rocks and Early Cretaceous 1104 dolerite sills in the northern and central segments, while it also affects Mesozoic successions in 1105 the southernmost segment. Early deformation along the zone is represented by steep reverse 1106 faults and convergent flexures parallel to the major fault strands indicating that the Lomfjorden 1107 Fault Zone was affected by Eurekan E-W shortening during a first phase in the early Eocene, 1108 most probably coeval with the development of the West Spitsbergen Fold-and-Thrust Belt. The 1109 reverse faults in the northern and central segments of the Lomfjorden Fault Zone correspond to 1110 the deep-seated, basement-involved and reactivated faults in the southern segment, which have 
1111 there been suggested to occur under the Mesozoic successions. The detachment zones, which

1112 controlled the structural development in the southern segment, must have been eroded farther N.

1113 There instead, a much deeper detachment horizon is required in the basement, which may be a

1114 reactivated Ellesmerian detachment.

1116 This convergent deformation was, in conformity with the transform plate margin development to

1117 the W, followed by strike-slip movements along the Lomfjorden Fault Zone during a second

1118 Eurekan phase in the late Eocene. The relative temporal succession of the two superimposed,

1119 dextral and sinistral, strike-slip regimes remains uncertain. Strike-slip deformation included

1120 transpressional and transtensional structures between the main fault strands. A particularly

1121 prominent feature is a transfer zone between the Lomfjorden and Agardhbukta faults just $\mathrm{N}$ of a

1122 major granite body (Newtontoppen Granite), which seems to control the position of the faults by

1123 deflecting them around it. The location of the Lomfjorden Fault Zone and its main fault strands

1124 is most likely inherited from Caledonian and/or Carboniferous structures. Being zones of crustal

1125 weakness, these were reactivated during the Eurekan deformation and the break-up of Laurasia.

\section{ACKNOWLEDGMENTS}

1130 Structural fieldwork in eastern Ny-Friesland was carried out during joint expeditions of the 1131 Norwegian Polar Institute (NP) and the German Federal Institute for Geosciences and Natural

1132 Resources (BGR) in 2001, 2005, 2006, and 2009. The expeditions were embedded in the

1133 Norway's mapping program and BGR's research program CASE (Circum-Arctic Structural

1134 Events) in cooperation with the universities of Bremen, Idaho, Munich, Troms $\emptyset$, and the natural

1135 museums of Berlin and Oslo. Winfried Dallmann is thankful to the Norwegian Polar Institute for

1136 long-term fieldwork support during the years 2005 to 2009. We would also like to thank Donald

1137 C. Murphy, Werner von Gosen, and the volume editors William C. McClelland and Lutz

1138 Reinhardt for many suggestions and comments on the manuscript, and Science Editor Christian

1139 Koeberl for handling this submission. Alvar Braathen's, Justin Strauss' and one anonymous

1140 reviewer's comments and suggestions helped to considerably improve the manuscript. 


\section{REFERENCES CITED}

Andresen, A., Bergh, S.G., and Haremo, P., 1994, Basin inversion and thin-skinned deformation

1146 associated with the Tertiary transpressional West Spitsbergen Orogen, in Thurston, D.K., and

1147 Fujita, K., eds., 1992 proceedings, International Conference on Arctic Margins, Anchorage,

1148 Alaska, September 1992: U.S. Deptartment of the Interior, Minerals Management Service,

1149 Alaska Outer Continental Shelf Region, p. 161-166.

1151 Andresen, A., Haremo, P., and Bergh, S.G., 1988, The southern termination of the Lomfjorden

1152 Fault Zone; evidence for Tertiary compression on East-Spitsbergen, in Dallmann, W.K., Ohta,

1153 Y., and Andresen, A., eds., Tertiary Tectonics of Svalbard, Extended abstracts from Symposium

1154 held in Oslo 26 and 27 April 1988: Norsk Polarinstitutt Rapportserie, v. 46, p. 75-78.

1156 Andresen, A., Haremo, P., Swensson, E., and Bergh, S.G., 1992, Structural geology around the 1157 southern termination of the Lomfjorden Fault Complex, Agardhdalen, east Spitsbergen, in 1158 Dallmann, W.K., Andresen, A., and Krill, A., eds., Post-Caledonian Tectonic Evolution of 1159 Svalbard, Proceedings from an International Conference held in Oslo 15-16 November 1990:

1160 Norsk Geologisk Tidsskrift, v. 72, p. 83-91.

1162 Barnes, C.J., and Schneider, D.A., 2018, this volume, chapter 7, Late Cretaceous-Paleogene 1163 burial and exhumation history of the Southwestern Basement Province, Svalbard, revealed by 1164 zircon (U-Th)/He thermochronology, in Piepjohn, K., Strauss, J.V., Reinhardt, L., and 1165 McClelland, W.C., eds., Circum-Arctic Structural Events: Tectonic Evolution of the Arctic 1166 Margins and Trans-Arctic Links with Adjacent Orogens: Geological Society of America Special 1167 Paper, v. 541, Chapter 7, https://doi.org/10.1130/2018.2541(07).

1169 Bartlett, W.L., Friedman, M., and Logan, J.M., 1981, Experimental folding and faulting of rocks 1170 under confining pressure. Part IX. Wrench faults in limestone layers: Tectonophysics, v. 79, p. $1171255-277$. 
1173 Beauchamp, B., Alonso-Torres, D., Piepjohn, K., Thériault, P., and Grasby, S.E., 2018, this

1174 volume, chapter 13, Early Carboniferous syn-rift sedimentation in the Sverdrup Basin (Yelverton

1175 Pass area, northern Ellesmere Island, Arctic Canada): A solution to the Okse Bay problem, in

1176 Piepjohn, K., Strauss, J.V., Reinhardt, L., and McClelland, W.C., eds., Circum-Arctic Structural

1177 Events: Tectonic Evolution of the Arctic Margins and Trans-Arctic Links with Adjacent

1178 Orogens: Geological Society of America Special Paper 541,

1179 https://doi.org/10.1130/2018.2541(13).

1181 Bergh, S.G., and Grogan, P., 2003, Tertiary structure of the Sørkapp-Hornsund Region, South

1182 Spitsbergen, and implications for the offshore southern extension of the fold-thrust belt:

1183 Norwegian Journal of Geology, v. 83, p. 43-60.

1185 Bergh, S.G., Braathen, A., and Maher Jr., H.D., 1994, The Lomfjorden fault zone: basement-

1186 controlled Carboniferous subsidence and Tertiary contractional reactivation in the Svalbard

1187 Foreland, East Spitsbergen: Tectonics and Structural Geology Studies Group of Norwegian

1188 Geological Society, (Nov. 10-11 1994), abstract, p. 20.

Bergh, S.G., Braathen, A., and Andresen, A., 1997, Interaction of basement-involved and thin-

1192 Association of Petroleum Geologists Bulletin, v. 81, p. 637-661.

1194 Bergh, S.G., Maher Jr., H.D., and Braathen, A., 2000, Tertiary divergent thrust directions from

1195 partitioned transpression, Brøggerhalvøya, Spitsbergen: Norsk Geologisk Tidsskrift, v. 80, p. 63119682.

1198 Bergh, S.G., Maher Jr., H.D., and Braathen, A., 2011, Late Devonian transpressional tectonics in

1199 Spitsbergen, Svalbard, and implications for basement uplift of the Sørkapp-Hornsund High:

1200 Journal of the Geological Society, v. 168, p. 441-456.

1202 Birkenmajer, K., 1972a, Tertiary history of Spitsbergen and continental drift: Acta Geologica 1203 Polonica, v. 22, no. 2, p. 200-218. 
1205 Birkenmajer, K., 1972b, Alpine fold belt of Spitsbergen: International Geological Congress, $24^{\text {th }}$ 1206 Session, p. 282-292.

1208 Birkenmajer, K., 1981, The Geology of Svalbard, the western part of the Barents Sea, and the 1209 continental margin of Scandinavia, in Nairn, A.E.M., Churkin, M., and Stehli, F.G., eds., The 1210 Ocean Basins and Margins. The Arctic Ocean: Plenum Press, v. 5, p. 265-329.

1212 Blinova, M., Faleide, J.I., Gabrielsen. R.H., and Mjelde, R., 2012, Seafloor expression and 1213 shallow structure of a fold-and-thrust system, Isfjorden, west Spitsbergen: Polar Research, v. 31, 1214 11209, http://dx.doi.org/10.3402/polar.v31i0.11209.

1216 Blinova, M., Faleide, J.I., Gabrielsen. R.H., and Mjelde, R., 2013, Analysis of structural trends 1217 of sub-sea-floor strata in the Isfjorden area of the West Spitsbergen Fold-and-Thrust Belt based 1218 on multichannel seismic data: Journal of the Geological Society, London, v. 170, p. 657-668. 1219 doi: 10.1144/jgs2012-109.

Braathen, A., Bergh, S.G., and Maher Jr., H.D., 1995, Structural outline of a Tertiary basementcored uplift/inversion structure in western Spitsbergen, Svalbard: Kinematics and controlling 1223 factors: Tectonics, v. 14, no. 1, p. 95-119. and folds during deposition of an evaporite-dominated half-graben basin; the Carboniferous

1227 Billefjorden Trough, Svalbard: Norwegian Journal of Geology, v. 91, p. 137-161.

1229 CASE Team, 2001, The evolution of the West Spitsbergen Fold-and-Thrust Belt, in Tessensohn, 1230 F., ed., Intra-Continental Fold Belts. CASE 1: West Spitsbergen: Geologisches Jahrbuch (Polar 1231 Issue No. 7) B 91, p. 733-773. 
1235 sedimentation: Society of Economic Paleontologists and Mineralogists, Special Publications, v. 1236 37, p. 1-34.

1238 Corfu, S.P., Polteau, S., Planke, S., Faleide, J.I., Svensen, H., Zayoncheck, A., and Stolbov, N., 1239 2013, U-Pb geochronology of Cretaceous magmatism on Svalbard and Franz Josef Land, 1240 Barents Sea Large Igneous Province: Geological Magazine, v. 150, no. 6, p. 1127-1135, doi:

$1241 \quad 10.1017 /$ S0016756813000162.

1243 Cutbill, J.L., and Challinor, A., 1965, Revision of the stratigraphical scheme of the 1244 Carboniferous and Permian rock of Spitsbergen and Bjørnøya: Geological Magazine, v. 102, p. $1245 \quad 418-439$.

1247 Dallmann, W.K., ed., 1999, Lithostratigraphic Lexicon of Svalbard - Review and 1248 recommendations for nomenclature use. Upper Palaeozoic to Quaternary Bedrock: Stratigrafisk 1249 Komité for Svalbard (SKS) - Committée on the Stratigraphy of Svalbard. Norsk Polarinstitutt, p. $1250 \quad 1-318$.

1251

1252 Dallmann, W.K., ed., 2015, Geoscience Atlas of Svalbard: Norsk Polarinstitutt Rapport Series, v. 1253 148, p. 1-292.

1254

1255 Dallmann, W. K., Andresen, A., Bergh, S. G., Maher Jr., H. D., and Ohta, Y., 1993, Tertiary 1256 fold-and-thrust belt of Spitsbergen, Svalbard: Norsk Polarinstitutt Meddelelser, v. 128, p. 1-46. 1257

1258 Dallmann, W.K., Ohta, Y., Elvevold, S., and Blomeier, D., 2002, Bedrock map of Svalbard and 1259 Jan Mayen, scale 1:750,000: Norsk Polarinstitutt Temakart 33.

1261 Dallmann, W.K., Ohta, Y., Birjukov, A.S., Karnoušenko, E.P., Sirotkin, A.N., and Piepjohn, K., 1262 2004, Geological map of Svalbard 1:100 000, sheet C7G Dicksonfjorden: Norsk Polarinstitutt 1263 Temakart 35. 
1265 Dallmann, W.K., Piepjohn, K., Elvevold, S., and Blomeier, D., 2009, Geological map of

1266 Svalbard 1:100 000, sheet D5G Lomfjordhalvøya: Norsk Polarinstitutt Temakart 44.

1268 Dallmann, W.K., Elvevold, S., Piepjohn, K., and Blomeier, D., 2010, Geological map of

1269 Svalbard 1:100 000, sheet C5G Åsgårdfonna: Norsk Polarinstitutt Temakart 46.

1270

1271 Dallmann, W.K., Piepjohn, K., Halverson, G.P., Elvevold, S., and Blomeier, D., 2011,

1272 Geological map of Svalbard 1:100 000, sheet D6G Vaigattbogen: Norsk Polarinstitutt Temakart 127348

1274

1275 De Paor, D., Bradley, D., Eisenstadt, G., and Phillips, S., 1989, The Arctic Eurekan orogen: A 1276 most unusual fold-and-thrust belt: Geological Society of America Bulletin, v. 101, no. 7, p. 9521277967.

1278

1279 Dörr, N., Lisker, F., Clift, P.D., Carter, A., Gee, D.G., Teben'kov, A.M., and Spiegel, C., 2012,

1280 Late Mesozoic-Cenozoic exhumation history of northern Svalbard and its regional significance:

1281 Constraints from apatite fission track analysis: Tectonophysics, v. 514-517, p. 81-92,

1282 doi:10.1016/j.tecto.2011.10.007.

1283

1284 Doré, A.G., Lundin, E.R., Gibbons, A., Sømme, T.P., and Tørudbakken, B.O., 2016, Transform 1285 margins of the Arctic: a synthesis and re-evaluation, in Nemčok, M., Rybar, S., Sinhar, S.T., 1286 Hermeston, S.A., and Ledvényiová, L., eds., Transform Margins: Development, Controls and 1287 Petroleum Systems: Geological Society of London, Special Publications, v. 431, p. 63-94.

1289 Døssing, A., Hopper, J.R., Olesen, A.V., Rasmussen, T.M., and Halpenny J., 2013, New aero1290 gravity results from the Arctic Ocean: Linking the latest Cretaceous-early Cenozoic plate 1291 kinematics of the North Atlantic and Arctic Ocean: Geochemistry, Geophysics. Geosystems, v. 1292 14, doi:10.1002/ggge.20253.

1293

1294 Eiken, O., 1985, Seismic mapping of the post-Caledonian strata in Svalbard: Polar Research, v. 1295 3, p. 167-176. 
1297 Elvevold, S., and Dallmann, W.K., 2011, Geological map of Svalbard 1:100 000, sheet C4G

1298 Mosselhalvøya: Norsk Polarinstitutt Temakart 47.

1300 Faehnrich, K., Schneider, D., Manecki, M., Czerny, J., Myhre, P.I., Majka, J., Kośmińska, K.,

1301 Barnes, C., and Maraszewska, M., 2017, Eurekan deformation on Prins Karls Forland, Svalbard

1302 - new insights from Ar40/Ar39 muscovite dating: EGU General Assembly 2017, v. 19, p. 642.

1304 Faleide, J.I., Bjorlykke, K., and Gabrielsen, R.H.O., 2010, Geology of the Norwegian

1305 Continental Shelf, in Bjorlykke, K., ed., Petroleum Geoscience: From Sedimentary

1306 Environments to Rock Physics, Springer, Berlin, p. 467-499.

1308 Frebold, H., 1935, Geologie von Spitzbergen, der Bäreninsel, des König Karl- und Franz-Joseph-

1309 Landes, in Krenkel, E., ed., Geologie der Erde: Gebrüder Borntraeger Berlin, 195 p.

1311 Friend, P.F., 1961, The Devonian stratigraphy of north and central Vestspitsbergen: Proceedings

1312 of the Yorkshire Geological Society, v. 33, p. 77-118.

1314 Friend, P. F., and Moody-Stuart, M., 1972, Sedimentation of the Wood Bay Formation

1315 (Devonian) of Spitsbergen: a regional analysis of a late orogenic basin: Norsk Polarinstitutt 1316 Skrifter, v. 157, p. 1-77.

1318 Gaina, C., Gernigon, L., and Ball, P., 2009, Palaeocene-Recent plate boundaries in the NE

1319 Atlantic and the formation of the Jan Mayen microcontinent: Journal of the Geological Society,

1320 London, v. 166, p. 601-616, http://dx.doi.org/10.1144/0016-76492008-112.

1322 Gayer, R.A., Gee, D.G., Harland, W.B., Miller, J.A., Spali, H.R., Wallis, H.R., and Winsnes,

1323 T.S., 1966, Radiometric age determinations on rocks from Spitsbergen: Norsk Polarinstitutt 1324 Skrifter, v. 137, p. 1-39. 
1326 Gee, D.G., and Moody-Stuart, M., 1966, The base of the Old Red Sandstone in central north

1327 Haakon VII Land, Vestspitsbergen: Norsk Polarinstitutt Årbok 1964, p. 57-68.

1329 Gee, D.G., and Teben'kov, A.M., 2004, Svalbard: A fragment of the Laurentian margin, in Gee, 1330 D.G., and Pease, V., eds., The Neoproterozoic Timanide Orogen of Eastern Baltica: Geological 1331 Society, London, Memoir, v. 30, p. 191-206.

1333 Gee, D.G., Johansson, A., Ohta, Y., Teben'kov, A.M., Krasil'ščhikov, A.A., Balashov, Y.A., 1334 Larionov, A.N., Gannibal, L.F., and Ryungenen, G.I., 1995, Grenvillian basement and a major 1335 unconformity within the Caledonides of Nordaustlandet, Svalbard: Precambrian Research, v. 70, 1336 no. 3-4, p. 215-234.

1338 Gion, A.M., Williams, S.E., and Müller, R.D., 2017, A reconstruction of the Eurekan Orogeny 1339 incorporating deformation constraints: Tectonics, v. 36, p. 304-320,

1340 doi:10.1002/2015TC004094.

1342 Halvorsen, E., 1974, The magnetic fabric of some dolerite intrusions, Northeast Spitsbergen;

1343 Implications for their mode of emplacement: Earth and Planetary Science Letters, v. 21, p. 127-1344133.

1346 Haremo, P., and Andresen, A., 1992, Tertiary decollement thrusting and inversion structures 1347 along Billefjorden and Lomfjorden fault zones, East Central Spitsbergen, in Larsen, R.M., 1348 Brekke, H., Larsen, B.T., and Talleras, E., eds., Structural and tectonic modelling and its 1349 application to petroleum geology: Norwegian Petroleum Society Special Publications, v. 1, p. 1350 481-494, https://doi.org/10.1016/B978-0-444-88607-1.50038-3.

1352 Haremo, P., Andresen, A., Dypvik, H., Nagy, J., Elverhoi, A., Eikeland, T.A., and Johansen, H., 1353 1990, Structural development along the Billefjorden Fault Zone in the area between 1354 Kjellstromdalen and Adventdalen/Sassendalen, central Spitsbergen: Polar Research, v. 8, p. 1951355216. 
1357 Haremo, P., Swensson, E., and Andresen, A., 1992, Evidence of Mesozoic extension along the 1358 Lomfjorden Fault Zone, Agardhbukta: Norsk Geologisk Tidsskrift, v. 136, p. 137.

1360 Harland, W.B., 1969, Contribution of Spitsbergen to understanding of tectonic evolution of 1361 North Atlantic region: American Association of Petroleum Geologists Memoir, v. 12, p. 817-1362851.

1364 Harland, W.B., 1973a, Mesozoic geology of Svalbard, in Pitcher, M.G., ed., Arctic Geology:

1365 American Association of Petroleum Geologists Memoir, v. 19, p. 135-148.

1367 Harland, W.B., 1973b, Tectonic evolution of Barents Shelf and related plates, in Pitcher, M.G., 1368 ed., Arctic Geology: American Association of Petroleum Geologists Memoir, v. 19, p. 599-608.

1370 Harland, W.B., 1979, A review of major faults in Svalbard, in Speed, R., Sharp, R., and 1371 Evernden, J.F., Proceedings of Conference VIII - Analysis of actual fault zones in bedrock, 1-5

1372 April 1979: Open File Report of the United States Geological Survey, v. 79-1239, p. 157-180. p.

1381 Harland, W.B., Wallis, R.H., and Gayer, R.A., 1966, A revision of the lower Hecla Hoek

1382 succession in central north Spitsbergen and correlation elsewhere: Geological Magazine, v. 193, p. 1383 70-97.

1385 Harland, W.B., Cutbill, J.L., Friend, P.F., Gobbett, D.J., Holliday, D.W., Maton, P.I., Parker, 1386 J.R., and Wallis, R.H., 1974, The Billefjorden Fault Zone, Spitsbergen. The long history of a 1387 major tectonic lineament: Norsk Polarinstistutt Skrifter, v. 161, 72 p. 
1389 Harland, W.B., Scott, R.A., Auckland, K.A., and Snape, I., 1992, The Ny-Friesland Orogen, Spits-

1390 Bergen: Geological Magazine, v. 129, no. 6, p. 679-708.

1392 Harrison, J.C., 2008, Regional variation in structural style, deformation kinematics, and 1393 summary of tectonic history, northeast Ellesmere Island, in Mayr, U., ed., Geology of northeast 1394 Ellesmere Island adjacent to Kane Basin and Nares Strait, Nunavut: Geological Survey of 1395 Canada Bulletin, v. 592, p. 245-284.

1397 Harrison, J.C., Brent, T.A., and Oakey, G.N., 2006, Sheet 1 of 2, Bedrock Geology, Nares Strait, 1398 scale 1:1,000,000. Bedrock geology of the Nares Strait region of Arctic Canada and Greenland, 1399 with explanatory text and GIS content: Geological Survey of Canada Open-File Report 5278.

1401 Håkansson, E., Heinberg, C., and Stemmerik, L., 1991, Mesozoic and Cenozoic history of the 1402 Wandel Sea Basin area, North Greenland, in Peel, J.S., and Sønderholm, M., eds., Sedimentary 1403 basins of North Greenland: Rapport Grønlands geologiske Undersøgelse, v. 160, p. 153-164.

1405 Henriksen, N., 1992, Geological Map of Greenland 1:500,000, Sheet 7 Nybøe Land, Sheet 8

1406 Peary Land: Grønlands Geologiske Undersøgelse, 40 p.

1408 Higgins, A.K., and Soper, N.J., 1983, The Lake Hazen fault zone: a transpresional upthrust?

1409 Current Research, Part B. Geological Survey of Canada, Paper 83-1B, p. 215-221.

1413 Hjelle, A., and Lauritzen, Ø., 1982, Geological map of Svalbard 1:500,000, sheet 3G,

1414 Spitsbergen northern part: Norsk Polarinstitutt Skrifter, v. 154c, p. 1-15.

1416 Hoeppener, R., 1955, Tektonik im Schiefergebirge. Eine Einführung: Geologische Rundschau, v. 1417 44, p. 26-58. 
1419 Kellogg, H.E., 1975, Tertiary stratigraphy and tectonism in Svalbard and continental Drift:

1420 American Association of Petroleum Geologists Bulletin, v. 59, p. 465-485.

1422 Klaper, E.M., 1990, The mid-Paleozoic deformation in the Hazen fold belt, Ellesmere Island, 1423 Arctic Canada: Canadian Journal of Earth Sciences, v. 27, p. 1359-1370.

Kleinspehn, K.L., and Teyssier, C., 2016, Oblique rifting and the Late Eocene-Oligocene demise 1426 of Laurasia with inception of Molloy Ridge: Deformation of Forlandsundet Basin, Svalbard:

1427 Tectonophysics. http://dx.doi.org/10.1016/j.tecto.2016.05.010.

1429 Lamar, D.L., Reed, W.E., and Douglass, D.N., 1986, The Billefjorden Fault Zone, Spitsbergen: 1430 is it part of a major Late Devonian transform? Geological Society of Amerca Bulletin, v. 97, p. $1431 \quad 1083-108$.

Larsen, B.T., 1988, Tertiary Thrust Tectonics in the east of Spitsbergen, and implications for the 1434 plate-tectonic development of the North-Atlantic, in Dallmann, W.K., Ohta, Y., and Andresen, 1435 A., eds., Tertiary Tectonics of Svalbard, extended abstracts from Symposium held in Oslo 26 and 143627 April 1988: Norsk Polarinstitutt Rapportserie, v. 46, p. 85-88.

1438 Leever, K.A., Gabrielsen, R.H., Faleide, J.I., and Braathen, A., 2011, A transpressional origin for 1439 the West Spitsbergen fold-and-thrust belt: Insight from analog modeling: Tectonics, v. 30,

1440 TC2014. doi: 10.1029/2010TC002753.

1442 Lyberis, N., and Manby, G.M., 1999, Continental collision and lateral escape deformation in the 1443 lower and upper crust: An example from Caledonide Svalbard: Tectonics, v. 18, p. 40-63.

1445 Maher Jr., H.D., 2001, Manifestations of the Cretaceous High Arctic Large Igneous Province in 1446 Svalbard: Journal of Geology, v. 109, p. 91-104, https://doi.org /10.1086/317960.

1448 Maher Jr., H.D., and Craddock, C., 1988, Decoupling as an alternate model for transpression 1449 during the initial opening of the Norwegian-Greenland Sea: Polar Research, v. 6, p. 137-140. 
1451 Maher Jr., H.D., and Braathen, A., 2011, Løvehovden fault and Billefjorden rift basin

1452 segmentation and development, Spitsbergen: Geological Magazine, v. 148, no. 1, p. 154-170, 1453 doi:10.1017/S0016756810000567.

1455 Maher Jr., H.D., Ringset, N., and Dallmann, W.K., 1989, Tertiary structures in the platform 1456 cover strata of Nordenskiold Land, Svalbard: Polar Research, v. 7, p. 83-93.

1458 Maher Jr., H.D., Bergh, S.G., Braathen, A., and Ohta, Y., 1997, Svartfjella, Eidembukta, and

1459 Daudmannsodden lineament: Tertiary orogen-parallel motion in the crystalline hinterland of 1460 Spitsbergen's fold-thrust belt: Tectonics, v. 16, no. 1, p. 88-106.

1462 Manby, G. M., 1990, The geology of the Harkerbreen Group, Ny-Friesland, Svalbard: protoliths 1463 and tectonic significance: Geological Magazine, v. 127, p. 129-146.

1465 Manby, G.M., and Lyberis, N., 1992, Tectonic evolution of the Devonian Basin of northern

1466 Svalbard, in Dallmann, W.K., Andresen, A., and Krill, A., eds., Post-Caledonian Tectonic

1467 Evolution of Svalbard, Proceedings from an International Conference held in Oslo 15-16

1468 November 1990: Norsk Geologisk Tidsskrift, v. 72, p. 7-19.

Manby, G.M., Lyberis, N., Chorowicz, J., and Thiedig, F., 1994, Post-Caledonian tectonics along the Billefjorden fault zone, Svalbard, and its implications for the Arctic region: Geological

1472 Society of America Bulletin, v. 105, p. 201-216.

1474 McCann, A.J., 2000, Deformation of the Old Red Sandstone of NW Spitsbergen; links to the 1475 Ellesmerian and Caledonian orogenies, in Friend, P.F., and Williams, B.P.J., eds., New 1476 Perspectives on the Old Red Sandstone: Geological Society, London, Special Publications, v. 1477180, p. 567-584.

1479 McCann, A.J., and Dallmann, W.K., 1996, Reactivation history of the long-lived Billefjorden 1480 Fault Zone in north central Spitsbergen, Svalbard: Geological Magazine, v. 133, no. 1, p. 63-84. 
1482 McClay, K.R., 1987, The Mapping of Geological Structures. Geological Society of London 1483 Handbook, vi + 161 p. Milton Keynes: Open University Press; New York, Toronto: Halsted 1484 Press, John Wiley. ISBN 033515096 9(OUP); 0470203552 (Halstead).

1486 Miloslavskij, M.J., Birjukov, A.S., Šlënskij, S.N., Hansen, S., Larsen, B.T., Dallmann, W.K., and 1487 Andresen, A., 1993a, Geological map of Svalbard 1:100 000, sheet D9G Agardhfjellet - Map: 1488 Norsk Polarinstitutt Temakart 21.

1490 Miloslavskij, M.J., Dallmann, W.K., Dypvik, H., Krasil'čšikov, A.A., Birkeland, Ø., and 1491 Salvigsen, O., 1993b, Geological Map of Svalbard 1:100,000, sheet D9G Agardhfjellet - Text: 1492 Norsk Polarinstitutt Temakart, v. 21, p. 1-41.

1494 Miloslavskij, M.J., Birjukov, A.S., Šlënskij, S.N., Krasil'čšikov, A.A., and Dallmann, W.K., 1495 1996, Geological map of Svalbard 1:100 000, sheet D8G Negribreen: Norsk Polarinstitutt 1496 Temakart 25.

1498 Murašov, L.G., and Mokin, J.I., 1979, Stratigraphic subdivision of the Devonian deposits of 1499 Spitsbergen: Norsk Polarinstitutt Skrifter, v. 167, p. 49-261.

Myhre, P.I., 2005, The tectonomagmatic evolution of Svalbard's northwestern terrane: U/Pb ages 1502 from Proterozoic crust and Caledonian magmatic evolution in Spitsbergen. Unpublished Master1503 thesis, University of Oslo, pp.

1505 Nathorst, A. G., 1910, Beiträge zur Geologie der Bären-Insel, Spitzbergens und des König-Karl1506 Landes: Bulletin of the Geological Institution of the University of Uppsala, v. 10, p. 261-416.

1508 Nøttvedt, A., Livbjerg, F., and Midbøe, P., 1988, Tertiary deformation on Svalbard - various 1509 models and recent advances, in Dallmann, W.K., Ohta, Y., and Andresen, A., eds., Tertiary 1510 Tectonics of Svalbard, Extended abstracts from Symposium held in Oslo 26 and 27 April 1988: 1511 Norsk Polarinstitutt Rapportserie, v. 46, p. 79-84. 
1513 Odell, N.E., 1927, Preliminary notes on the geology of the eastern parts of central Spitsbergen;

1514 with special reference to the problem of the Hecla Hook Formation: Quarterly Journal of the

1515 Geological Society, v. 83, p. 147-162.

1516

1517 Ohta, Y., 1988, Structure of Carboniferous strata at Tryghamna and along the SE margin of the 1518 Forlandsundet graben: Norsk Polarinstitutt Rapportserie, v. 46, p. 25-28.

1520 Okulitch, A.V., 1991, Geology of the Canadian Arctic Archipelago, Northwest Territories and 1521 North Greenland, scale 1:2,000,000, in Trettin, H.P., ed., Geology of the Innuitian Orogen and 1522 Arctic Platform of Canada and Greenland, Geology of Canada: Geological Survey of Canada, v. 15233.

1525 Okulitch, A.V., and Trettin, H.P., 1991, Late Cretaceous - Early Tertiary deformation, Arctic 1526 Islands, in Trettin, H.P., ed., Geology of the Innuitian Orogen and Arctic Platform of Canada and 1527 Greenland, Geology of Canada: Geological Survey of Canada, v. 3, p. 469-490.

Orvin, A.K., 1940, Outline of the geological history of Spitsbergen; Skrifter om Svalbard og Ishavet, v. 78, p. 1-57.

1532 Piepjohn, K., 1994, Tektonische Evolution der Devongräben (Old Red) in NW-Svalbard [PhD 1533 thesis]: Westfälische Wilhelms-Universität Münster, 170 p.

1535 Piepjohn, K., 2000, The Svalbardian/Ellesmerian deformation of the Old Red Sandstone and the 1536 pre-Devonian basement in NW-Spitsbergen (Svalbard), in Friend, P.F., and Williams, B.P.J., 1537 eds., New Perspectives on the Old Red Sandstone: Geological Society, London, Special 1538 Publications, v. 180, p. 585-601.

1540 Piepjohn, K., and Dallmann, W.K., 2014, Stratigraphy of the uppermost Old Red Sandstone of 1541 Svalbard (Mimerdalen Subgroup): Polar Research, v. 33, doi: org/10.3402/polar.v33. 19998. 
1543 Piepjohn, K., and von Gosen, W., 2001, Polyphase deformation at the Harder Fjord Fault Zone 1544 (North Greenland): Geological Magazine, v. 138, no. 4, p. 407-434.

1546 Piepjohn, K., and von Gosen, W., 2017, Structural transect through Ellesmere Island (Canadian 1547 Arctic): superimposed Palaeozoic Ellesmerian and Cenozoic Eurekan deformation, in Pease, V., 1548 and Coakley, B., eds., Circum-Arctic Lithosphere Evolution: Geological Society, London, 1549 Special Publications, v. 460, p. 33-56, https://doi.org/10.1144/SP460.5.

1551 Piepjohn, K., Brinkmann, L., Grewing, A., and Kerp, H., 2000a, New data on the age of the 1552 uppermost ORS and the lowermost post-ORS strata in Dickson Land (Spitsbergen) and 1553 implications for the age of the Svalbardian deformation, in Friend, P.F., and Williams, B.P.J., 1554 eds., New Perspectives on the Old Red Sandstone: Geological Society London, Special 1555 Publications, v. 180, p. 603-609.

1557 Piepjohn, K., Tessensohn, F., Harrison, C., and Mayr, U., 2000b, Involvement of a Tertiary 1558 Foreland Basin in the Eurekan Foldbelt Deformation, NW Coast of Kane Basin, Ellesmere 1559 Island, Canada: Polarforschung, v. 68, p. 101-110.

1561 Piepjohn, K., von Gosen, W., Tessensohn, F., and Saalmann, K., 2008, Ellesmerian fold-and1562 thrust belt (northeast Ellesmere Island, Nunavut) and its Eurekan overprint, in Mayr, U., ed., 1563 Geology of northeast Ellesmere Island adjacent to Kane Basin and Nares Strait, Nunavut: 1564 Geological Survey of Canada Bulletin, v. 592, p. 285-303.

1566 Piepjohn, K., von Gosen, W., Läufer, A., McClelland, W.C., and Estrada, S., 2013, Ellesmerian 1567 and Eurekan fault tectonics at the northern margin of Ellesmere Island (Canadian High Arctic): 1568 Zeitschrift der Deutschen Gesellschaft für Geowissenschaften (German Journal of Geosciences), 1569 v. 164, no. 1, p. 81-105, doi: 10.1127/1860-1804/2013/0007.

1571 Piepjohn, K., von Gosen, W., Tessensohn, F., Reinhardt, L., McClelland, W.C., Dallmann, W., 1572 Gaedicke, C., and Harrison, J.C., 2015, Tectonic map of the Ellesmerian and Eurekan 
1573 deformation belts on Svalbard, North Greenland, and the Queen Elizabeth Islands (Canadian 1574 Arctic): arktos, v. 1, doi: 10.1007/s41063-015-0015-7.

1576 Piepjohn, K., von Gosen, W., and Tessensohn, F., 2016, The Eurekan Deformation in the Arctic: 1577 an outline: Journal of the Geological Society, v. 173, doi: 10.1144/jgs2016-081.

1579 Playford, G., 1962/63, Lower Carboniferous microfloras of Spitsbergen: Palaeontology, v. 5, no. $15803-4$, p. 550-678.

1582 Riis, F., and Vollset, J., 1988, A preliminary interpretation of the Hornsund Fault Complex 1583 between Sørkapp and Bjørnøya, in Dallmann, W.K., Ohta, Y., and Andresen, A., eds., Tertiary 1584 Tectonics of Svalbard, extended abstracts from Symposium held in Oslo 26 and 27 April 1988: 1585 Norsk Polarinstitutt Rapportserie, v. 46, p. 91-92.

1587 Ringset N., and Andresen, A., 1988, The Gipshuken Fault System - evidence for Tertiary 1588 thrusting along the Billefjorden Fault Zone, in Dallmann, W.K., Ohta, Y., and Andresen, A., 1589 eds., Tertiary Tectonics of Svalbard, extended abstracts from Symposium held in Oslo 26 and 27 1590 April 1988: Norsk Polarinstitutt Rapportserie, v. 46, p. 67-70.

1592 Saalmann, K., Tessensohn, F., Piepjohn, K., von Gosen, W., and Mayr, U., 2005, Structure of 1593 Palaeogene sediments in east Ellesmere Island: Constraints on Eurekan tectonic evolution and 1594 implications for the Nares Strait Problem: Tectonophysics, v. 406, p. 81-113.

1596 Saalmann, K., Tessensohn, F., von Gosen, W., and Piepjohn, K., 2008, Structural evolution of 1597 Tertiary rocks on Judge Daly Promontory, in Mayr, U., ed., Geology of northeast Ellesmere 1598 Island adjacent to Kane Basin and Nares Strait, Nunavut: Geological Survey of Canada Bulletin, 1599 v. 592, p. 305-323.

1600

1601 Scheibner, C., Hartkopf-Fröder, C., Blomeier, D., and Forke, H., 2012, The Mississippian

1602 (Lower Carboniferous) in northeast Spitsbergen (Svalbard) and a re-evaluation of the 
1603 Billefjorden Group: Zeitschrift der Deutschen Gesellschaft für Geowissenschaften (German

1604 Journal of Geosciences), v. 163, no. 3, p. 293-308.

1605

1606 Schneider, D.A., Faehnrich, K., Majka, J., and Manecki, M., 2018, this volume, chapter 8,

1607 40Ar/39Ar geochronologic evidence of Eurekan deformation within the West Spitsbergen Fold

1608 and Thrust Belt, in Piepjohn, K., Strauss, J.V., Reinhardt, L., and McClelland, W.C., eds.,

1609 Circum-Arctic Structural Events: Tectonic Evolution of the Arctic Margins and Trans-Arctic

1610 Links with Adjacent Orogens: Geological Society of America, v. 541, Chapter 8,

1611 https://doi.org/10.1130/2018.2541(08).

1612

1613 Senger, K., Tveranger, J., Ogata, K., Braathen, A., and Planke, S., 2014, Late Mesozoic

1614 magmatism in Svalbard: A review: Earth-Science Reviews, v. 139, p. 123-144,

1615 http://dx.doi.org/10.1016/j.earscirev.2014.09.002.

1616

1617 Sigmond, E.M.O., 2002, Geological map, Land and Sea Areas of Northern Europe. Scale 1:4

1618 million. Geological Survey of Norway.

Skilbrei, J.R., and Srivastava, S.P., 1993, Appendix: Greenland-Svalbard Plate Kinematics in the

1621 Tertiary and its relation to the west-Spitsbergen orogeny and structural highs in the western

1622 Barents Sea, in Interpretation of Geophysical Data from the Northwestern Barents Sea and

1623 Spitsbergen: Ph.D. thesis, Doktor Ing., 20 p.

1624

1625 Soper, N.J., and Higgins, A.K., 1987, A shallow detachment beneath the North Greenland fold

1626 belt: implications for sedimentation and tectonics: Geological Magazine, v. 124, no. 5, p. 441-1627450.

1628

1629 Soper, N.J., and Higgins, A.K., 1991, Devonian - Early Carboniferous deformation and

1630 metamorphism, North Greenland). A. Deformation, in Trettin, H.P., ed., Geology of the Innuitian

1631 Orogen and Arctic Platform of Canada and Greenland, Geology of Canada: Geological Survey of

1632 Canada, v. 3, p. 283-288. 
1634 Soper, N.J., Dawes, P.R., and Higgins, A.K., 1982, Cretaceous-Tertiary magmatic and tectonic 1635 events in North Greenland and the history of adjacent oceanic basins, in Dawes P.R., and Kerr,

1636 J.W., eds., Nares Strait and the drift of Greenland: a conflict in plate tectonics: Meddelelser om 1637 Grønland, Geoscience, v. 8, p. 205-220.

1639 Sømme, T.O., Doré, A.G., Lundin, E.R., and Tørudbakken, B.O., 2018, Triassic-Paleogene 1640 paleogeography of the Arctic: Implications for sediment routing and basin fill: AAPG Bulletin, 1641 v. 102 , no. 12 , p. 2481-2517, doi: 10.1306/05111817254.

1643 Srivastava, S.P., 1978, Evolution of the Labrador Sea and its bearing on the early evolution of 1644 the North Atlantic: Geophysical Journal of the Royal Astronomical Society, v. 52, no. 2, p. 313-1645357.

1646

1647 Srivastava, S.P., 1985, Evolution of the Eurasian Basin and its implications to the motion of 1648 Greenland along Nares Strait: Tectonophysics, v. 114, p. 29-53.

1650 Srivastava, S.P., and Tapscott, C.R., 1986, Plate kinematics of the North Atlantic, in Vogt, P.R., 1651 and Tucholke, B.E., eds., The Geology of North America: Geological Society of America, 1652 Boulder, v. M., The Western North Atlantic Region, p. 379-405.

1654 Steel, R.J., and Worsley, D., 1984, Svalbard's post-Caledonian strata - an atlas of 1655 sedimentational patterns and palaeogeographic evolution, in Spencer, A.M., Holter, E., Johnson, 1656 S.O., Mørk, A., Nysæther, E., Songstad, P., and Spinnangr, Å., eds., Petroleum Geology of the 1657 North European Margin: Graham \& Trotman, London, p. 109-135.

1659 Stephenson, R., Piepjohn, K., Schiffer, C. von Gosen, W., Oakey, G.N., and Anudu, G., 2017, 1660 Integrated crustal-geological cross-section of Ellesmere Island, in Pease, V., and Coakley, B., 1661 eds., Circum-Arctic Lithosphere Evolution. Geological Society, London, Special Publications, v. 1662 460, https://doi.org/10.1144/SP460.12 
1664 Suess, E., 1888, Das Antlitz der Erde. Vol. I-III. Leipzig and Prague: F. Tempsky and G.

1665 Freytag, 778 p.

1666

1667 Talwani, M., and Eldholm, O., 1977, Evolution of the Norwegian - Greenland Sea: Geological

1668 Society of America Bulletin, v. 88, p. 969-999.

1669

1670 Tchalenko, J.S., and Ambraseys, N.N., 1970, Structural analyses of the Dasht-e Baȳaz (Iran)

1671 earthquake fractures: Geological Society of America Bulletin, v. 81, p. 41-60.

1672

1673 Teben'kov, A.M., Ohta, Y., Balashov, J.A., and Sirotkin, A.N., 1996, Newtontoppen granitoid

1674 rocks; their geology, chemistry and Rb-Sr age: Polar Research, v. 15, p. 67-80.

1675

1676 Tegner, C., Storey, M., Holm, P.M., Thorarinsson, S.B., Zhao, X., Lo, C.-H., and Knudsen,

1677 M.F., 2011, Magmatism and Eurekan deformation in the High Arctic Large Igneous Province:

$1678{ }^{40} \mathrm{Ar}^{39} \mathrm{Ar}$ age of Kap Washington Group volcanics, North Greenland: Earth and Planetary

1679 Science Letters, v. 303, no. 3-4, p. 203-214.

1680

1681 Tessensohn, F., ed., 2001, Intra-Continental Fold Belts. CASE 1: West Spitsbergen:

1682 Geologisches Jahrbuch (Polar Issue No. 7) B 91, p. 1-773.

1683

1684 Tessensohn, F., and Piepjohn, K., 2000, Eocene compressive deformation in Arctic Canada,

1685 North Greenland and Svalbard and its plate tectonic causes: Polarforschung, v. 68, p. 121-124.

1687 Tessensohn, F., Henjes-Kunst, F., and Krumm, S., 2001, K/Ar Dating Attempts on Rocks from 1688 the West Spitsbergen Fold-and-Thrust Belt and the Central Basin, in Tessensohn, F., ed., Intra1689 Continental Fold Belts. CASE 1: West Spitsbergen: Geologisches Jahrbuch (Polar Issue No. 7) B 169091, p. 719-728.

1692 Tessensohn, F., von Gosen, W., Piepjohn, K., Saalmann, K., and Mayr, U., 2008, Nares

1693 transform motion and Eurekan compression along the northeast coast of Ellesmere Island, in 
1694 Mayr, U., ed., Geology of northeast Ellesmere Island adjacent to Kane Basin and Nares Strait, 1695 Nunavut: Geological Survey of Canada Bulletin, v. 592, p. 227-243.

1697 Thorsteinsson, R., and Tozer, E.T., 1970, Geology of the Arctic Archipelago, in Douglass, 1698 R.J.W, ed., Geology and Economic Minerals of Canada: Geological Survey of Canada, 1699 Economic Geology Report, v. 1, p. 547-590.

1701 Tsikalas, F., Faleide, J.I., and Eldholm, O., 2012, The North Atlantic conjugate margins, in 1702 Roberts, D.G., and Bally, A.W., eds., Principles of Phanerozoic Regional Geology. Phanerozoic 1703 Passive Margins, Cratonic Basins and Global Tectonic Maps. Elsevier, Amsterdam, p. 141-201. 1704

1705 Vink, G.E., 1982, Continental rifting and the implications for plate tectonic reconstructions:

1706 Journal of Geophysical Research, v. 87, p. 10677-10688.

1707

1708 Vogt, T., 1928, Den norske fjellkjedes revolusjonshistorie: Norsk Geologisk Tidsskrift, v. 10, p. 1709 97-115.

1710

1711 von Gosen, W., and Piepjohn, K., 1999, Evolution of the Kap Cannon Thrust Zone (north

1712 Greenland): Tectonics, v. 18, no. 6, p. 1004-1026.

1713

1714 von Gosen, W., and Piepjohn, K., 2003, Eurekan transpressive deformation in the Wandel Hav

1715 Mobile Belt (northeast Greenland): Tectonics, v. 22, no. 4, p. 13-28.

1716

1717 von Gosen, W., Piepjohn, K., Tessensohn, F., and Saalmann, K., 2008, Eurekan fault tectonics 1718 on Judge Daly Promontory and their implications for displacements along Nares Strait, in Mayr, 1719 U., ed., Geology of northeast Ellesmere Island adjacent to Kane Basin and Nares Strait, Nunavut: 1720 Geological Survey of Canada Bulletin, v. 592, p. 325-346.

1722 von Gosen, W., Piepjohn, K., and Reinhardt, L., 2012, Polyphase Eurekan deformation along the 1723 Vendom Fiord Fault Zone on south Ellesmere Island (Canadian Arctic) and its possible relation 
1724 to the Wegener Fault: Zeitschrift der Deutschen Gesellschaft für Geowissenschaften (German

1725 Journal of Geosciences), v. 163, no. 3, p. 261-282.

1726

1727 von Gosen, W., Piepjohn, K., Gilotti, J.A., McClelland, W.B., and Reinhardt, L. 2018, this

1728 volume, chapter 18, Structural evidence for sinistral displacement on the Wegener Fault in

1729 southern Nares Strait, Arctic Canada, in Piepjohn, K., Strauss, J.V., Reinhardt, L., and

1730 McClelland, W.C., eds., Circum-Arctic Structural Events: Tectonic Evolution of the Arctic

1731 Margins and Trans-Arctic Links with Adjacent Orogens: Geological Society of America Special

1732 Paper, v. 541.

1733

1734 Wilcox, R.E., Harding, T.P., and Seely, D.R., 1973, Basic wrench tectonics: American

1735 Association of Petroleum Geologists Bulletin, v. 57, p. 74-96.

1736

1737 Woodcock, N.H., and Fischer, M., 1986, Strike-slip duplexes: Journal of Structural Geology, v.

1738 8, p. 725-735.

1739

1740

\section{FIGURE CAPTIONS}

1742

1743 Figure 1: Tectonic map of northeastern Ellesmere Island, North Greenland, and Svalbard

1744 showing the sedimentary basins, the areas affected by the Caledonian, Ellesmerian, and Eurekan

1745 orogenies, and the most important fault zones (redrawn from Okulitch, 1991; Håkansson et al.,

1746 1991; Henriksen, 1992; Dallmann et al., 1993, 2002; Harrison et al., 2006; Piepjohn et al., 2013,

1747 2015, 2016; Dallmann, 2015). BFZ-Billefjorden Fault Zone, HFFZ-Harder Fjord Fault Zone,

1748 KCTZ-Kap Cannon Thrust Zone, LFZ-Lomfjorden Fault Zone, and WHSSB-Wandel Hav

1749 Strike-Slip Belt.

1750

1751 Figure 2: (A) Simplified geological map of Svalbard (Hjelle, 1993; Dallmann, 2015) showing the

1752 locations of the West Spitsbergen Fold-and-Thrust Belt, the Billefjorden Fault Zone, and the

1753 Lomfjorden Fault Zone. Frame shows location of Fig. 2B, and the location of profile of Fig. 20 is

1754 also shown. (B) Simplified geological map of the Lomfjorden Fault Zone in eastern Spitsbergen 
1755 between Hinlopenstretet in the $\mathrm{N}$ and Agardhbukta in the south (redrawn from Miloslavskij et 1756 al., 1993a, b, 1996, and Dallmann et al., 2002, 2011). Frame shows location of Fig. 3.

1758 Figure 3: Geological map of the northern and central segment of the Lomfjorden Fault Zone 1759 between Valhallfonna in the $\mathrm{N}$ and Andromedafjellet in the south, redrawn and simplified from 1760 Dallmann et al. (2002, 2009, 2010, 2011). Locations of cross-sections A-A' and B-B' of Figure 17614 are shown. Locations of outcrop areas described in the text and figures are shown in Figure 6. 1762 BFR-Bjørnfjellet Reverse Fault, DRF-Dolerittfjellet Reverse Fault, LRF-Lomfjella Reverse 1763 Faults, SHF-Sillhøgda Fault, and UFA-Ursafonna Anticline.

1765 Figure 4: Geological cross-sections across the Lomfjorden Fault Zone (A) from the Eolussletta 1766 Shear Zone through Lomfjella and southern Lomfjorden towards Lomfjordhalvøya, and (B) 1767 between Langfjellet and Vaigattbogen, based on Dallmann et al. $(2009,2011)$ as well as present 1768 fieldwork. Note the fault-dominated area of the Atomfjella Complex W of the Veteranen Fault 1769 and the km-scale fold structures with subvertical fold limbs in the Lomfjorden Supergroup to the 1770 E (for location of cross-sections see Fig. 3).

1772 Figure 5: Caledonian structures: Lower hemisphere stereographic projections (equal area) of 1773 bedding planes $S_{0}$, cleavage planes $S_{1}, \delta_{1}$-intersection lineations, and $B_{1}$-fold axes in

1774 Neoproterozoic sediments of the (A) Veteranen Group and (B) of the Akademikarbreen, 1775 Polarisbreen, and Oslobreen groups demonstrating the dominating architecture of Caledonian 1776 folding.

1778 Figure 6: Map of the study area showing the locations of described outcrop areas and figures in 1779 the study (A) along the northern segment of the Lomfjorden Fault Zone between Kapp Fanshawe 1780 in the $\mathrm{N}$ and Andromedafjellet in the $\mathrm{S}$ and (B) along the central segment between

1781 Andromedafjellet in the $\mathrm{N}$ and Malte Brunfjellet in the S. The location of profile of Fig. 17B is 1782 shown. BFR-Bjørnfjellet Reverse Fault, DRF-Dolerittfjellet Reverse Fault, LRF-Lomfjella 1783 Reverse Faults, and SHF-Sillhøgda Fault. 
1785 Figure 7: (A) Geological map of the area SW of Kapp Fanshawe, redrawn from Dallmann et al. 1786 (2009). Red circle shows location of Fig. 7B. (B) Tectonic sketch map of the NNE-SSW striking 1787 fault in Neoproterozoic deposits of the Akademikarbreen Group SW of Kapp Fanshawe (for 1788 location see Figs. 6 and 7A). (C) Lower hemisphere stereographic projections (equal area) of 1789 fabric elements. Slickenside lineations are projected on the poles of the related planes, arrows 1790 indicate the relative sense of shear/displacement of the hanging wall units (Hoeppener, 1955). 1791

1792 Figure 8: Lower hemisphere stereographic projections (equal area) of fabric elements in (A) 1793 Neoproterozoic limestones of the Akademikarbreen Group and (B) Carboniferous limestones at 1794 the coast W of Mjølnerfjellet (for location see Fig. 6). Slickenside lineations are projected on the 1795 poles of the related planes, arrows indicate the relative sense of shear/displacement of the 1796 hanging wall units (Hoeppener, 1955). (C) NE-vergent fold structure and thrust fault in 1797 limestones of the Carboniferous Wordiekammen Formation at Mjølnerfjellet (for location see 1798 Fig. 6). (D) Diagram to an inferred tectonic scenario at Mjølnerfjellet showing ideal fault 1799 orientations in a N-S trending dextral strike-slip system. The diagram is based on Wilcox et al. 1800 (1973) and Christie-Blick and Biddle (1985); see text for explanation.

1802 Figure 9: (A) Geological map of NE-dipping strata of the upper Veteranen, Akademikarbreen 1803 and lower Polarisbreen groups at the mountains Geren and Freken at the E-coast of Lomfjorden 1804 (for location see Fig. 6). The tilted rocks are truncated by NE-SW striking subvertical faults with 1805 a dextral sense of displacement that is documented by about $100 \mathrm{~m}$ of right-lateral offset of the 1806 boundary between the Veteranen and Akademikarbreen groups. (B) Lower hemisphere 1807 stereographic projections (equal area) of fabric elements in the Veteranen and Akademikarbreen 1808 groups at Geren and Freken. Slickenside lineations are projected on the poles of the related 1809 planes, arrows indicate the relative sense of shear/displacement of the hanging wall units 1810 (Hoeppener, 1955). (C) Diagrams to inferred tectonic scenarios demonstrated by a schematic 1811 pure shear-strain ellipse with ideal fault orientations in an E-W convergent system $\left(\mathrm{C}_{1}\right)$ and ideal 1812 fault orientations in $\mathrm{N}-\mathrm{S}$ trending dextral $\left(\mathrm{C}_{2}\right)$ and sinistral $\left(\mathrm{C}_{3}\right)$ strike-slip systems. Diagrams are 1813 based on Wilcox et al. (1973) and Christie-Blick and Biddle (1985); see tect for explanation. 
1815 Figure 10: (A) The Eastern Lomfjella Reverse Fault at the W-coast of Lomfjorden N of

1816 Lomfjordbotnen (for location see Fig. 6). The reverse fault carries Neoproterozoic sedimentary

1817 rocks of the Veteranen Group westwards on top of Early Carboniferous deposits of the

1818 Billefjorden Group and Early Cretaceous dolerites. (B) Schematic block sketch of details of the

1819 reverse fault in (A). The floor thrust and back thrusts are marked in red colour. (C) Lower

1820 hemisphere stereographic projections (equal area) of fabric elements in the Veteranen Group in

1821 the hanging wall of the reverse faults. Slickenside lineations are projected on the poles of the

1822 related planes, arrows indicate the relative sense of shear/displacement of the hanging wall units

1823 (Hoeppener, 1955). (D) Diagram to an inferred tectonic scenario demonstrated by a schematic

1824 pure shear-strain ellipse with ideal fault orientations in an E-W convergent system. The diagram

1825 is based on Wilcox et al. (1973) and Christie-Blick and Biddle (1985); see tect for explanation.

1827 Figure 11: W-dipping Bjørnfjellet Reverse Fault (A) E of Bjørnfjellet (view towards the NNE)

1828 and (B) at Løveryggen (view towards the S) carrying Neoproterozoic red beds of the Veteranen

1829 Group eastwards over horizontal middle Carboniferous to Early Permian limestones and Early

1830 Cretaceous dolerite sills (for location see Fig. 6). (C) Lower hemisphere stereographic

1831 projections (equal area) of fabric elements in the Veteranen sandstones from the outcrop group in

1832 the Bjørnfjellet area (for location see Fig. 6). Slickenside lineations are projected on the poles of

1833 the related planes, arrows indicate the relative sense of shear/displacement of the hanging wall

1834 units (Hoeppener, 1955).

1836 Figure 12: Folded and thrust-faulted limestones and dolomites of the Carboniferous

1837 Wordiekammen and Gipshuken formations at Vinkelen/Chydenuisbreen (for location see Fig. 6).

1838 The thrust ramp is NNW-directed, and the $\mathrm{F}_{2}$-folds are oriented NNE-SSW.

1840 Figure 13: (A) WNW-directed thrust at Raudberget with Neoproterozoic deposits of the

1841 Lomfjorden Supergroup and unconformably overlying limestones of the Carboniferous

1842 Wordiekammen Formation in the hanging wall (for location see Fig. 6). (B) SW-vergent fold-

1843 structure in the hanging wall of the thrust (for location see Fig. 13A). (C) Lower hemisphere

1844 stereographic projections (equal area) of fabric elements in Carboniferous limestones at

1845 Raudberget. Slickenside lineations are projected on the poles of the related shear planes, arrows 
1846 indicate the relative sense of shear/displacement of the hanging wall units (Hoeppener, 1955).

1847 (D) Diagrams to inferred tectonic scenarios demonstrated by ideal fault orientations in N-S

1848 trending dextral $\left(\mathrm{D}_{1}\right)$ and sinistral $\left(\mathrm{D}_{2}\right)$ strike-slip systems. The diagrams are based on Wilcox et

1849 al. (1973) and Christie-Blick and Biddle (1985); see tect for explanation.

1851 Figure 14: (A) Geological map of the Polarisbreen area (for location see Fig. 6). The offset of the

1852 boundaries of the Veteranen, Akademikarbreen, and Polarisbreen groups of the ENE-dipping

1853 Neoproterozoic Lomfjorden Supergroup proves the dextral sense of displacements along the

1854 NE-SW striking strike-slip faults. Location of profile of Fig. 14B is also shown. (B) Geological

1855 W-E cross-section of the Polarisbreen area (for location see Figure 14A). (C) Lower hemisphere

1856 stereographic projections (equal area) of fabric elements in Neoproterozoic and Carboniferous

1857 rocks at Grovtoppane SE of Chydeniusbreen, outcrops A925 and 946 (for locations see

1858 Figs.14A). Slickenside lineations are projected on the poles of the related planes, arrows indicate

1859 the relative sense of shear/displacement of the hanging wall units (Hoeppener, 1955). (D)

1860 Diagram to an inferred tectonic scenario demonstrated by a schematic pure shear-strain ellipse

1861 with ideal fault orientations in an E-W convergent system. The diagram is based on Wilcox et al.

1862 (1973) and Christie-Blick and Biddle (1985); see tect for explanation.

1864 Figure 15: (A) Simplified profile across the Dolerittfjellet Reverse Fault and Sillhøgda Fault 1865 between Oslobreen and Ditlovtoppen (for location see Fig. 15B). (B) Geological map of the 1866 Oslobreen area (redrawn from own field data and Dallmann et al., 2011) (for location see Fig. 6). 1867 Note the parallel orientation of NNW-SSE striking normal faults and the Dolerittfjellet Reverse 1868 Fault. Note also the pattern of small-scale strike-slip faults between Kvitrevbreen and Oslobreen. 1869 The numbers refer to outrcops described in the text. Location of profile of Fig. 15A is also 1870 shown. ABF-Agardhbukta Fault. (C) Simplified profile across the Sillhøgda Fault S of 1871 Kirtonryggen (for location see Fig. 15B). (D) Lower hemisphere stereographic projections (equal 1872 area) of fabric elements in Cambrian and Carboniferous rocks, and Cretaceous dolerite sills at 1873 the Sillhøgda Fault S of Kyrtonryggen (outcrops A949-951, for locations see Fig. 15B).

1874 Slickenside lineations are projected on the poles of the related planes, arrows indicate the relative 1875 sense of shear/displacement of the hanging wall units (Hoeppener, 1955). 
1877 Figure 16: (A) Dolerittfjellet Reverse Fault carrying Neoproterozoic rocks to the ENE over 1878 horizontal Carboniferous limestones and Cretaceous dolerite sills at Dolerittfjellet. Lower 1879 hemisphere stereographic projections (equal area) of fabric elements in (B) Neoproterozoic rocks 1880 of the hanging wall (outcrops A932 and A934) and (C) in Carboniferous limestones and an Early 1881 Cretaceous dolerite sill in the footwall of the Dolerittfjellet Reverse Fault (outcrops A933 and 1882 A935, for locations see Fig. 15B). Slickenside lineations are projected on the poles of the related 1883 planes, arrows indicate the relative sense of shear/displacement of the hanging wall units 1884 (Hoeppener, 1955). (D) Diagrams to inferred tectonic scenarios demonstrated by a schematic 1885 pure shear-strain ellipse with ideal fault orientations in a local ENE-WSW convergent system in 1886 the vicinity of the Dolerittfjellet Reverse Fault $\left(\mathrm{D}_{1}\right)$ and by ideal fault orientations in N-S 1887 trending sinistral $\left(\mathrm{D}_{2}\right)$ and dextral $\left(\mathrm{D}_{3}\right)$ strike-slip systems. The diagrams are based on Wilcox et 1888 al. (1973) and Christie-Blick and Biddle (1985); see tect for explanation.

1890 Figure 17: Lower hemisphere stereographic projections (equal area) of fabric elements in 1891 Carboniferous rocks at (A) Pachtusovfjellet and (C) in Neoproterozoic rocks at Vivienberget (for 1892 locations see Fig. 6B). Slickenside lineations are projected on the poles of the related planes, 1893 arrows indicate the relative sense of shear/displacement of the hanging wall units (Hoeppener, 1894 1955). (B) Simplifiedc W-E profile through the monocline at Pachtusovfjellet and the 1895 Agardhbukta Fault. (D) Diagrams to inferred tectonic scenarios demonstrated by schematic pure 1896 shear-strain ellipse with ideal fault orientations in a local E-W convergent system at 1897 Pachtusovfjellet $\left(\mathrm{D}_{1}\right)$ and by ideal fault orientations in a NNE-SSW trending dextral strike-slip 1898 system at Vivienberget $\left(\mathrm{D}_{2}\right)$. The diagrams are based on Wilcox et al. (1973) and Christie-Blick 1899 and Biddle (1985); see tect for explanation.

1901 Figure 18: Lower hemisphere stereographic projections (equal area) of fabric elements in 1902 Carboniferous to Permian sedimentary rocks at Malte Brunfjellet (for location see Fig. 6B). (A) 1903 Fabric elements interpreted as compatible with a dextral, and (B) with a sinistral strike-slip 1904 scenario in Carboniferous/Permian sedimentary rocks near the Agardhbukta Fault. Slickenside 1905 lineations are projected on the poles of the related planes, arrows indicate the relative sense of 1906 shear/displacement of the hanging wall units (Hoeppener, 1955). (C) Diagrams to inferred 1907 tectonic scenarios demonstrated by a schematic pure shear-strain ellipse with ideal fault 
1908 orientations in (C1) a W-E contractional scenario, and by ideal fault orientations (C2) in a 1909 sinistral N-S strike-slip scenario, and (C3) in a dextral N-S strike-slip scenario. The diagrams 1910 are based on Wilcox et al. (1973) and Christie-Blick and Biddle (1985); see tect for explanation.

1912 Figure 19: Map of the Lomfjorden Fault Zone showing the left-stepping Lomfjorden and 1913 Agardhbukta faults wthin a dextral scenario with a contractional overstep (A) and within a 1914 sinistral scenario with an extensional overstep (B). The squares depict the main kinematics in 1915 the observed outcrops indicating the lateral movements by half-arrows and the corresponding 1916 shortening directions (yellow arrows) and extension directions (green arrows). The two insets 1917 show schematic sketches based on McClay (1987) with $\left(\mathrm{A}_{1}\right)$ left-stepping faults generating zones 1918 of compression with folds and thrusts in a dextral strike-slip system and $\left(\mathrm{B}_{1}\right)$ left-stepping faults 1919 generating zone of extension (normal faults) in a sinistral strike-slip system.

1921 Figure 20: WSW-ENE cross section through the West Spitsbergen Fold-and-Thrust Belt, the 1922 Central Tertiary Basin, the southern segment of the Lomfjorden Fault Zone and the Ny-Friesland 1923 Block in the central part of Spitsbergen (redrawn and modified from Nøttvedt et al., 1988), two 1924 times exaggerated (for location of see Figure 2A). Note the detachment zones in the Triassic and 1925 Jurassic rocks and the assumed detachment in the pre-Devonian basement rocks.

1927 Figure 21: Possible reconstruction of Svalbard, North Greenland, and the Queen Elizabeth 1928 Islands at approximately anomaly 21 (47 Ma) with the indication of the active faults during the 1929 phases of the Eurekan Orogeny (modified from Piepjohn et al., 2016, and citations therein). 1930 AFFZ-Archer Fiord Fault Zone, BFZ-Billefjorden Fault Zone, FFZ-Feilden Fault Zone, HFFZ1931 Harder Fjord Fault Zone, KCTZ-Kap Cannon Thrust Zone, LHFZ-Lake Hazen Fault Zone, 1932 LFZ-Lomfjorden Fault Zone, MRF-Mount Rawlinson Fault, PGT-Parrish Glacier Thrust, 1933 SEDL-Svartfjella-Eidembukta-Daudmannsodden Lineament, VFFZ-Vendom Fiord Fault Zone, 1934 and WHSSB-Wandel Hav Strike-Slip Belt. 


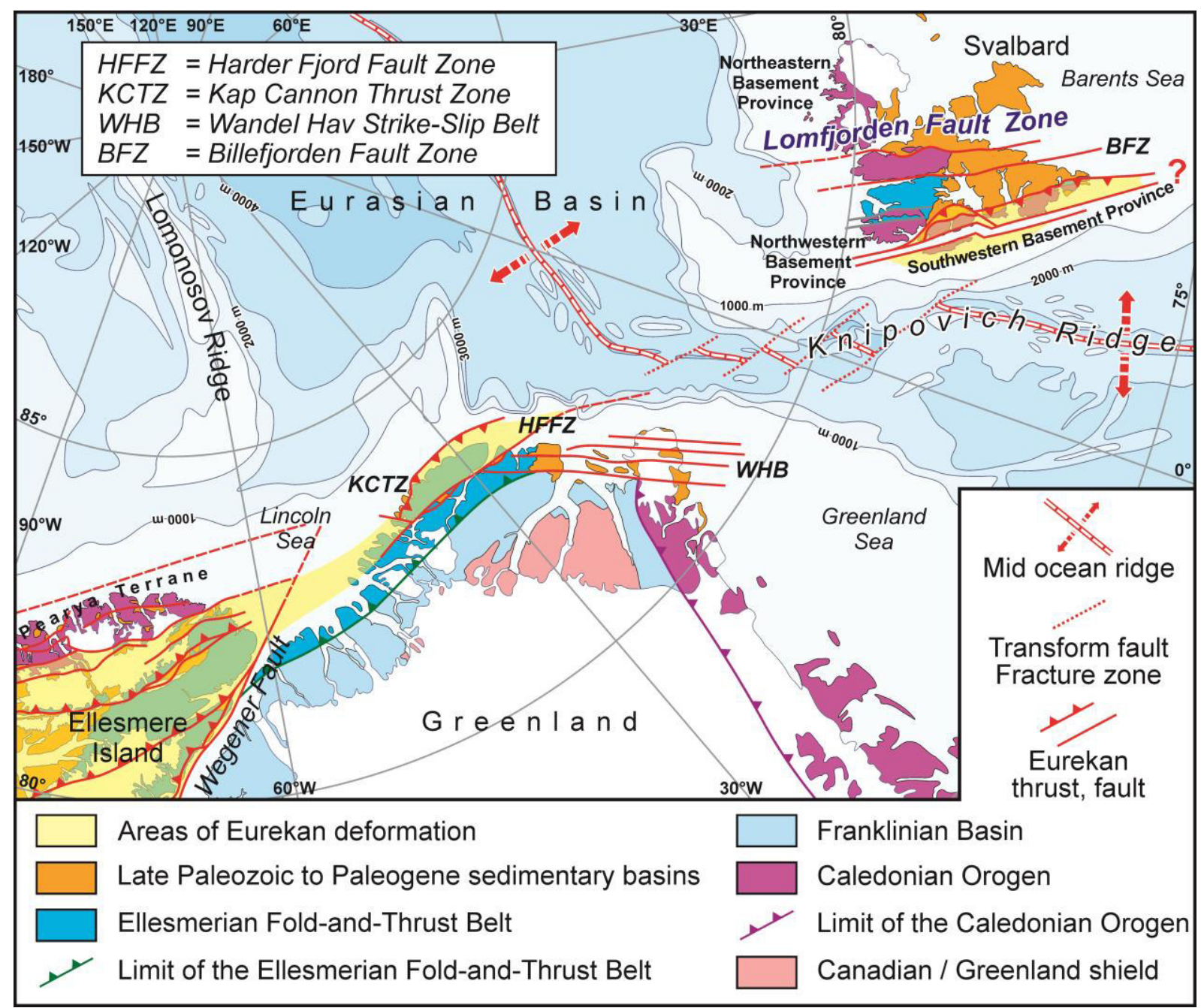

Figure 1 


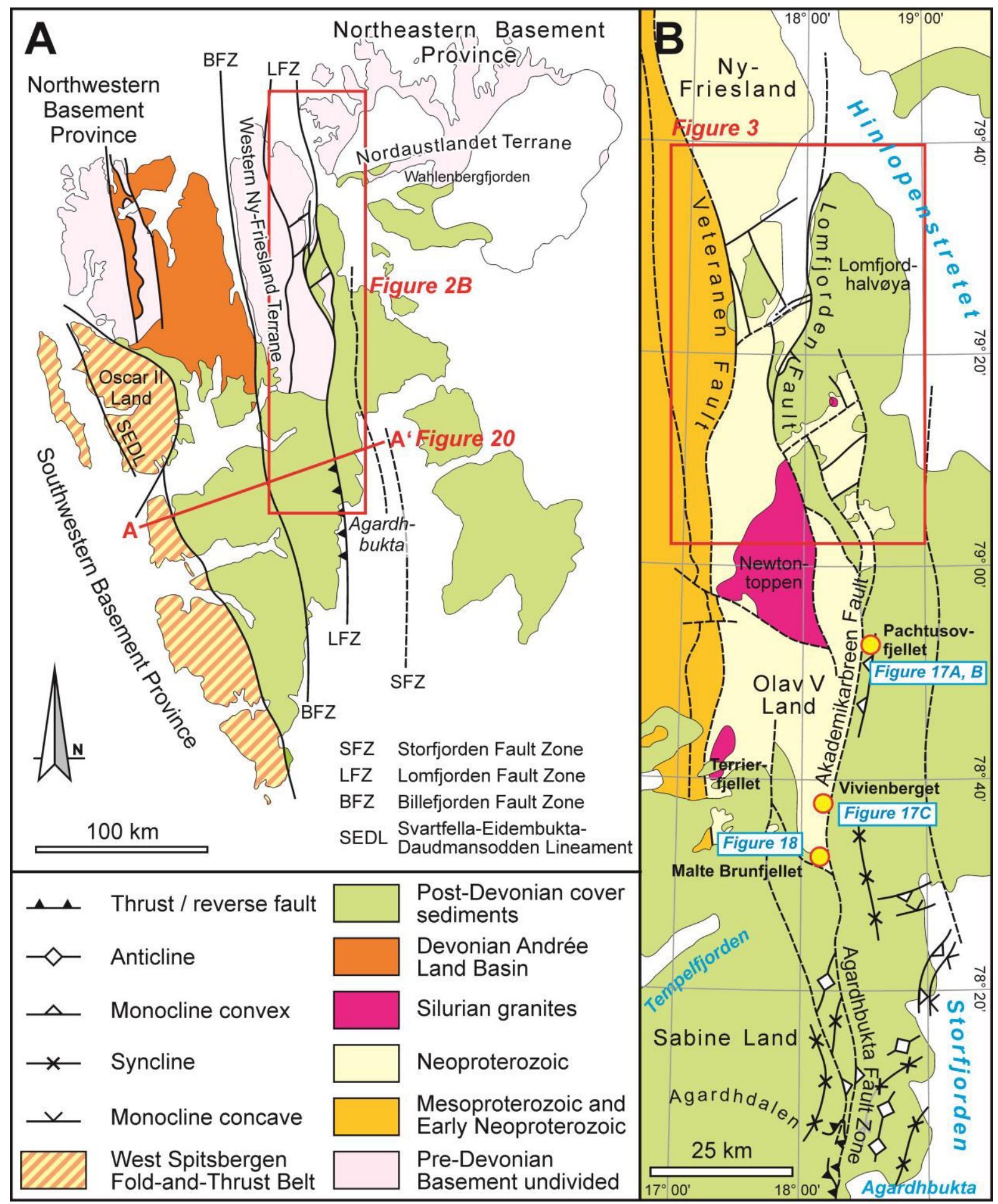

Figure 2 


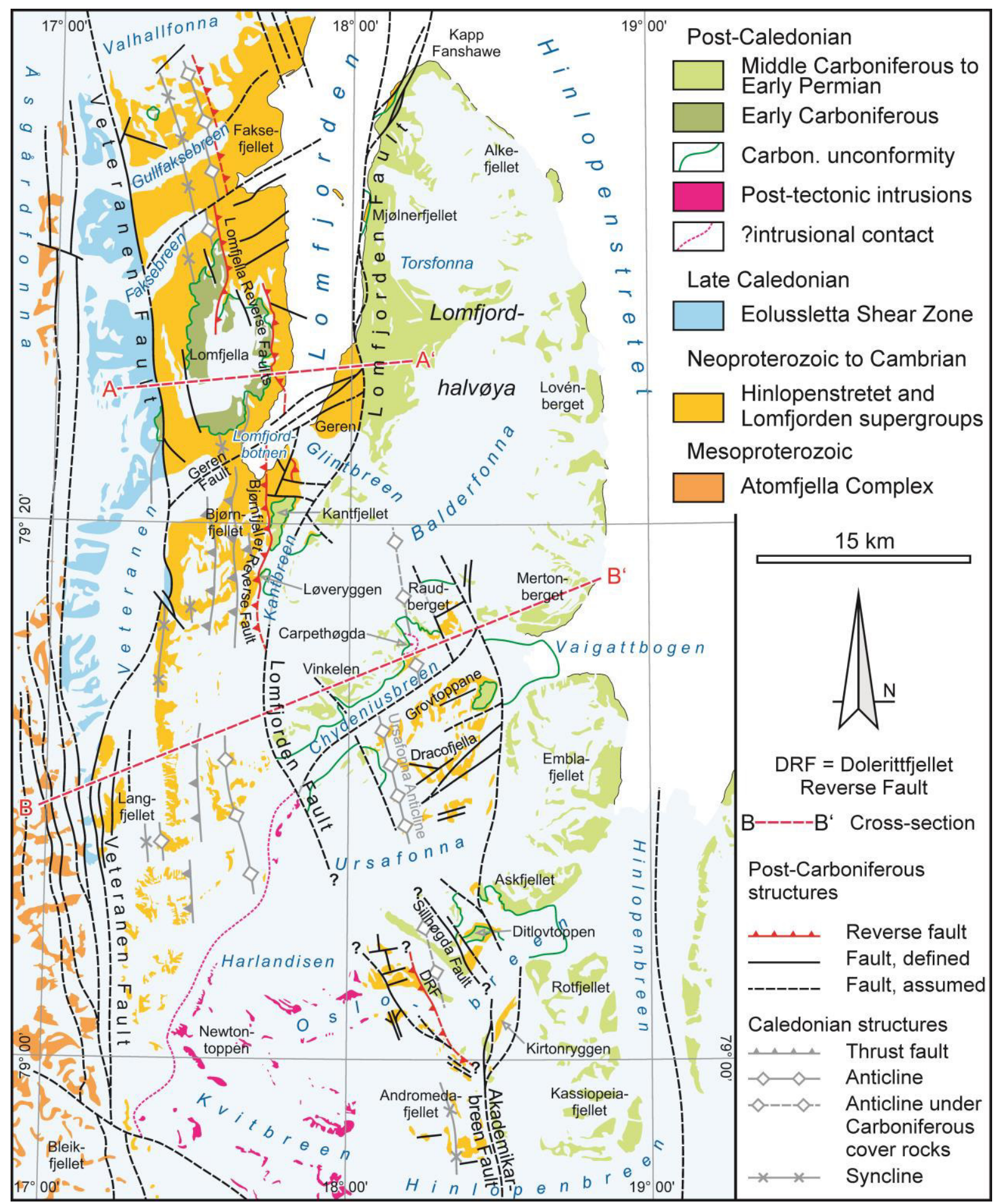

Figure 3 neu 


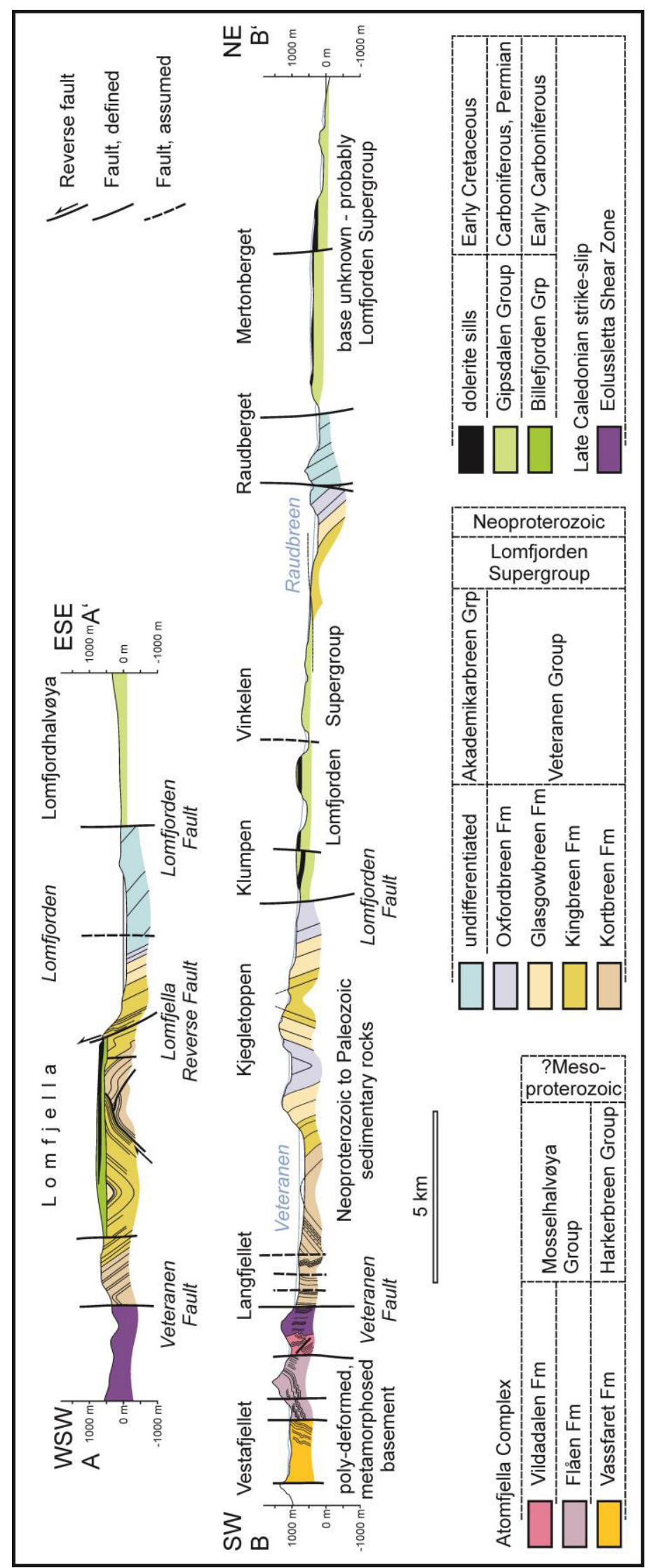

Figure 4 


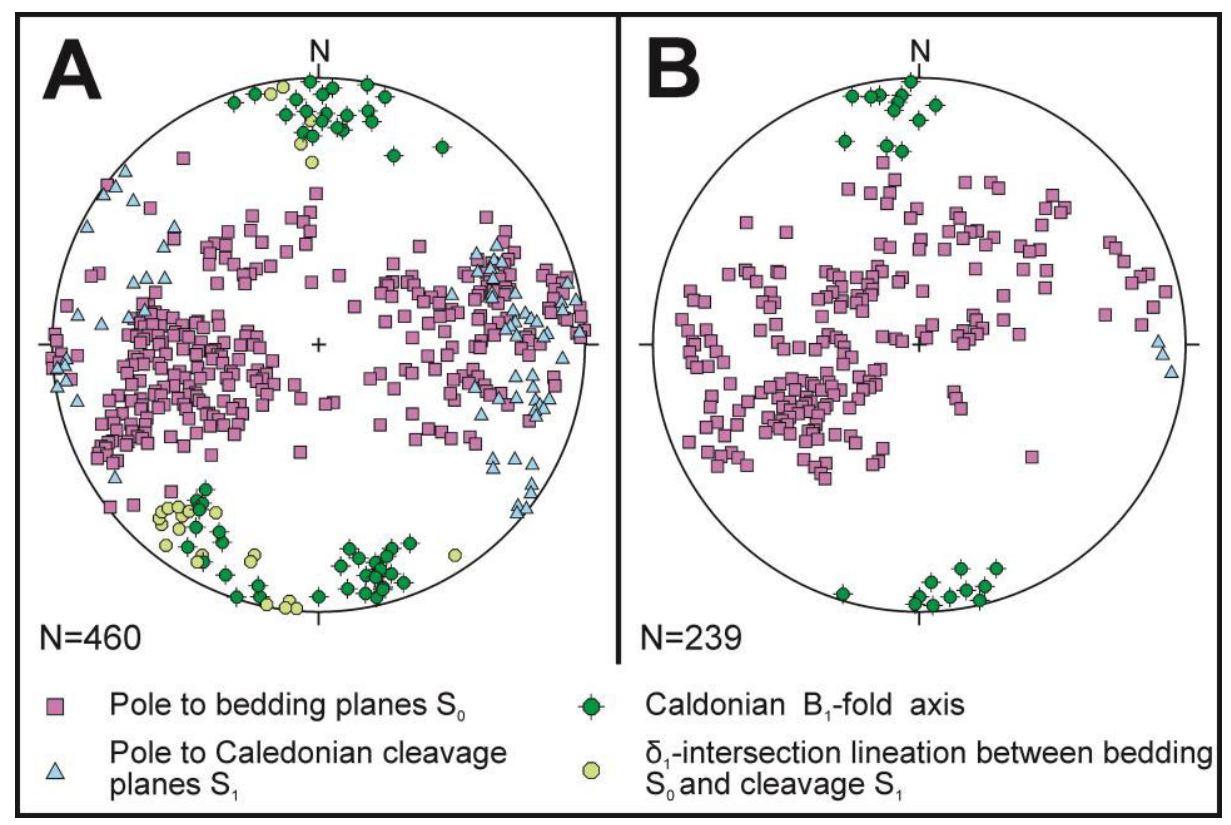

Figure 5 


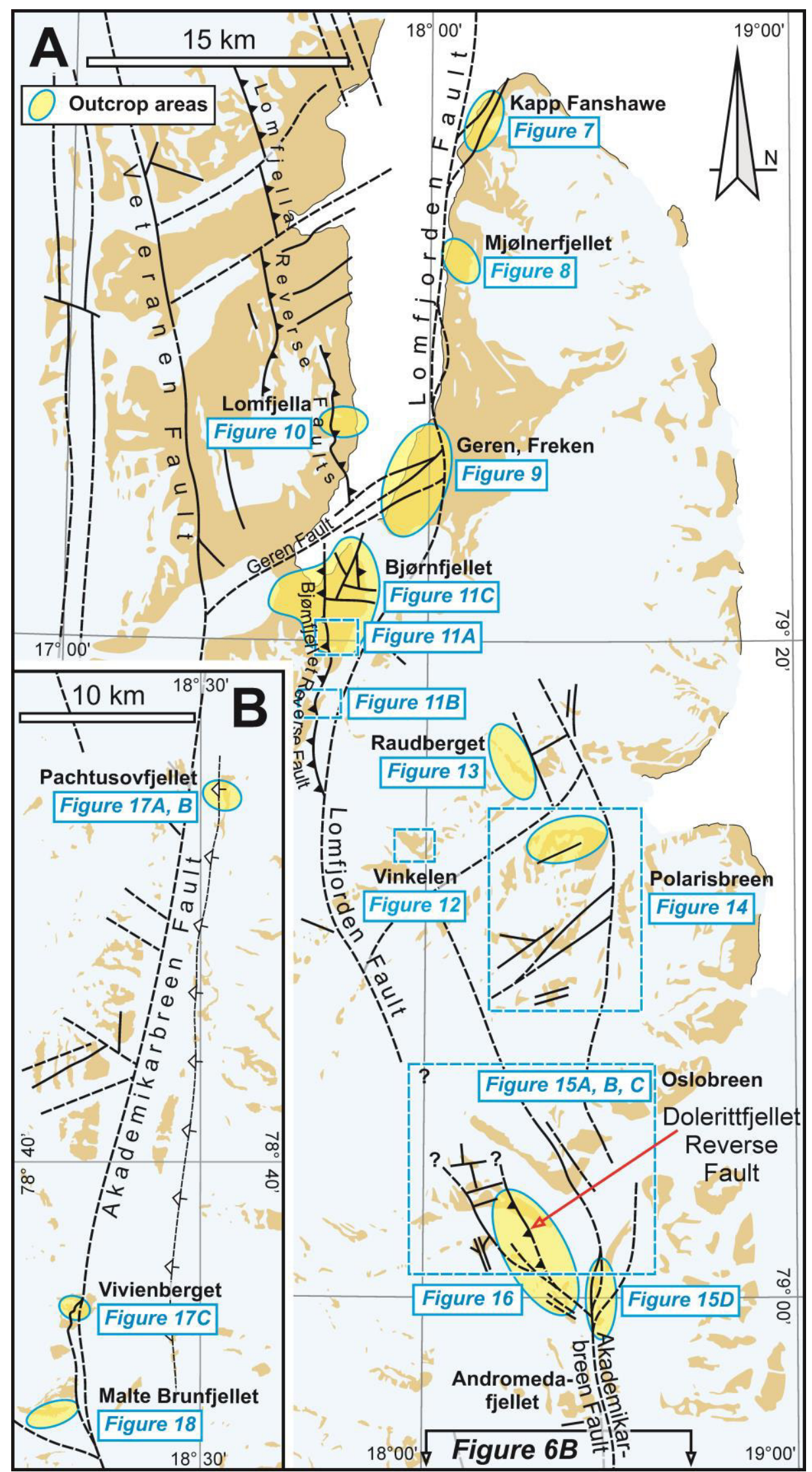

Figure 6 neu 


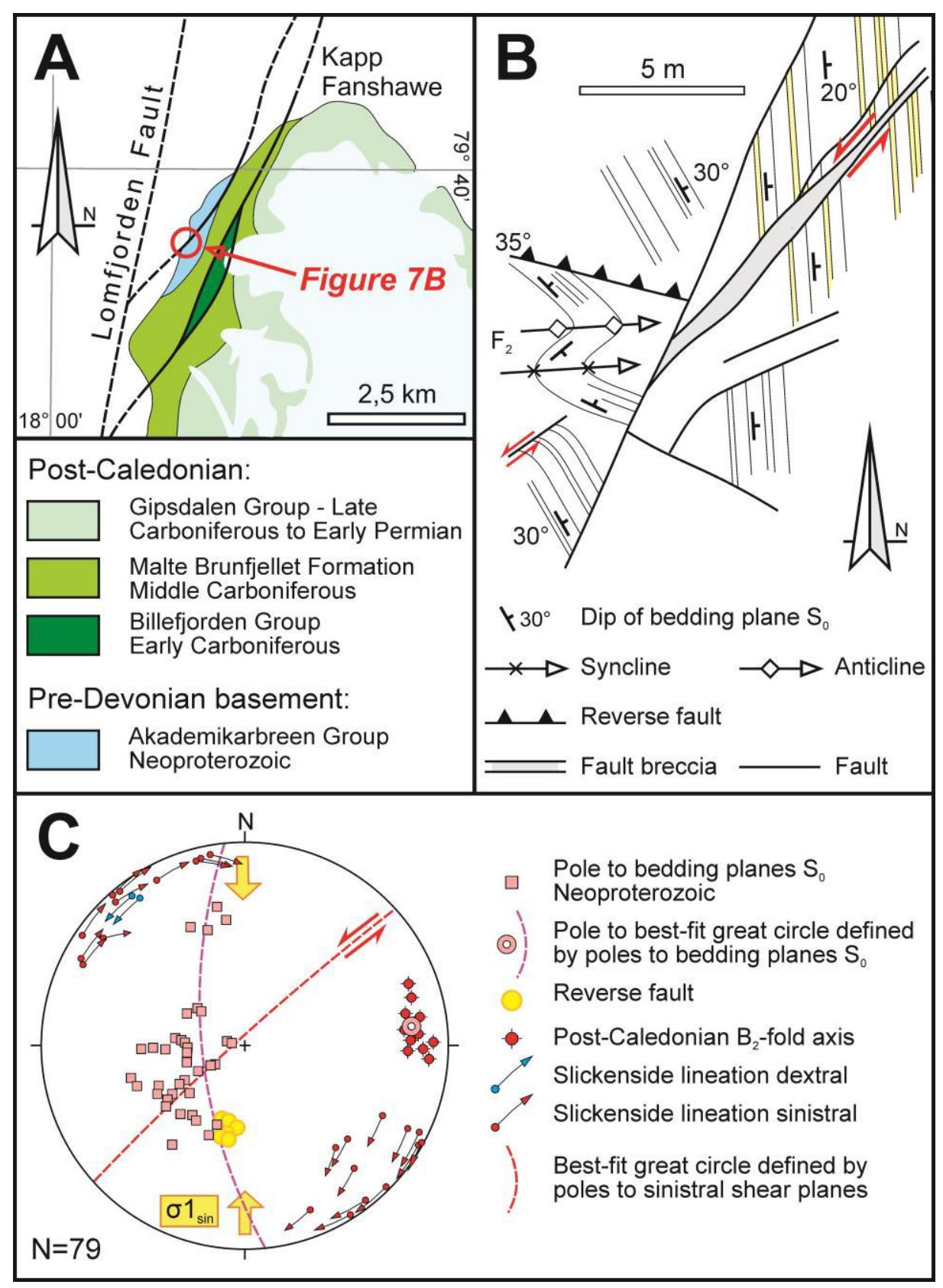

Figure 7 neu 


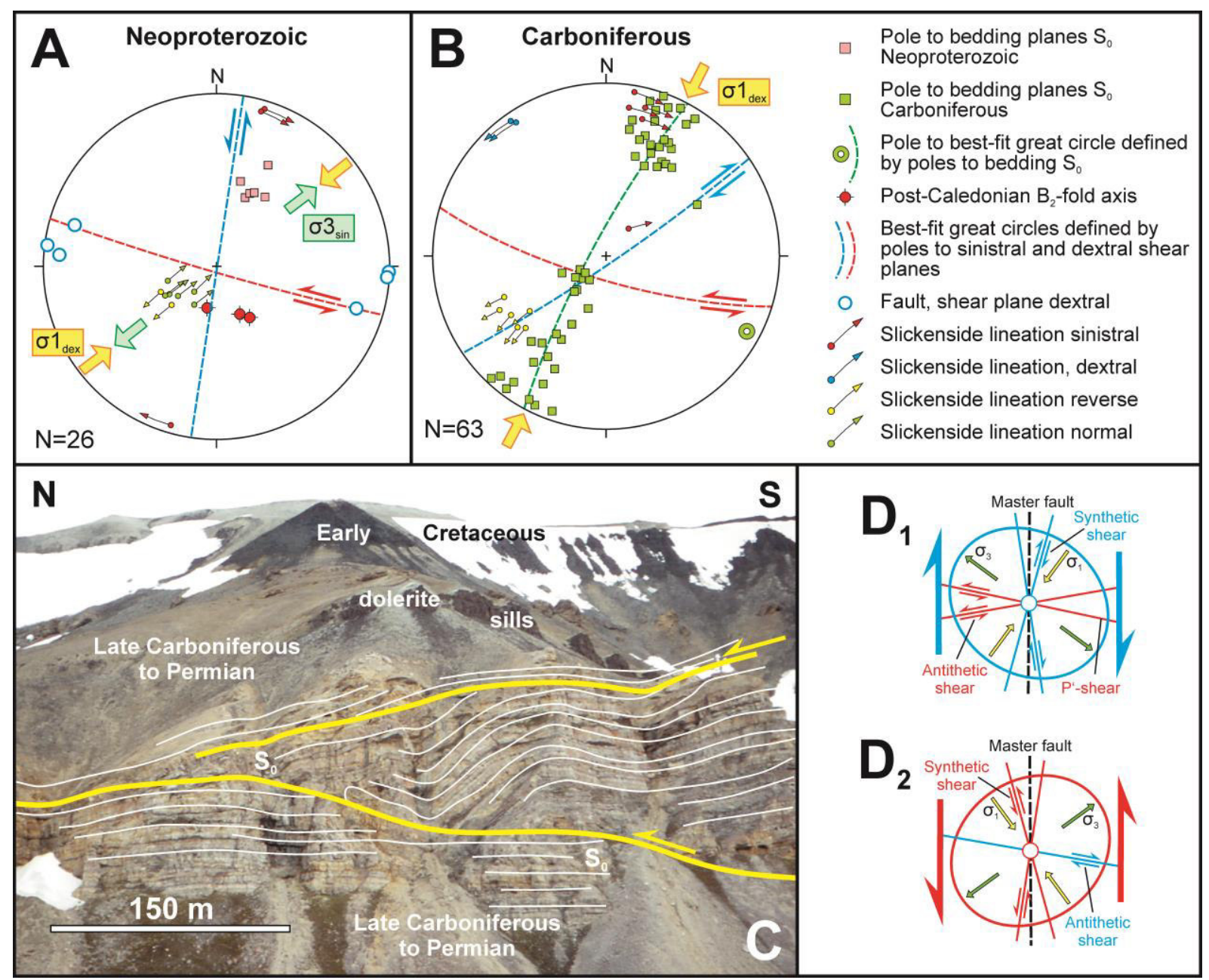

Figure 8 


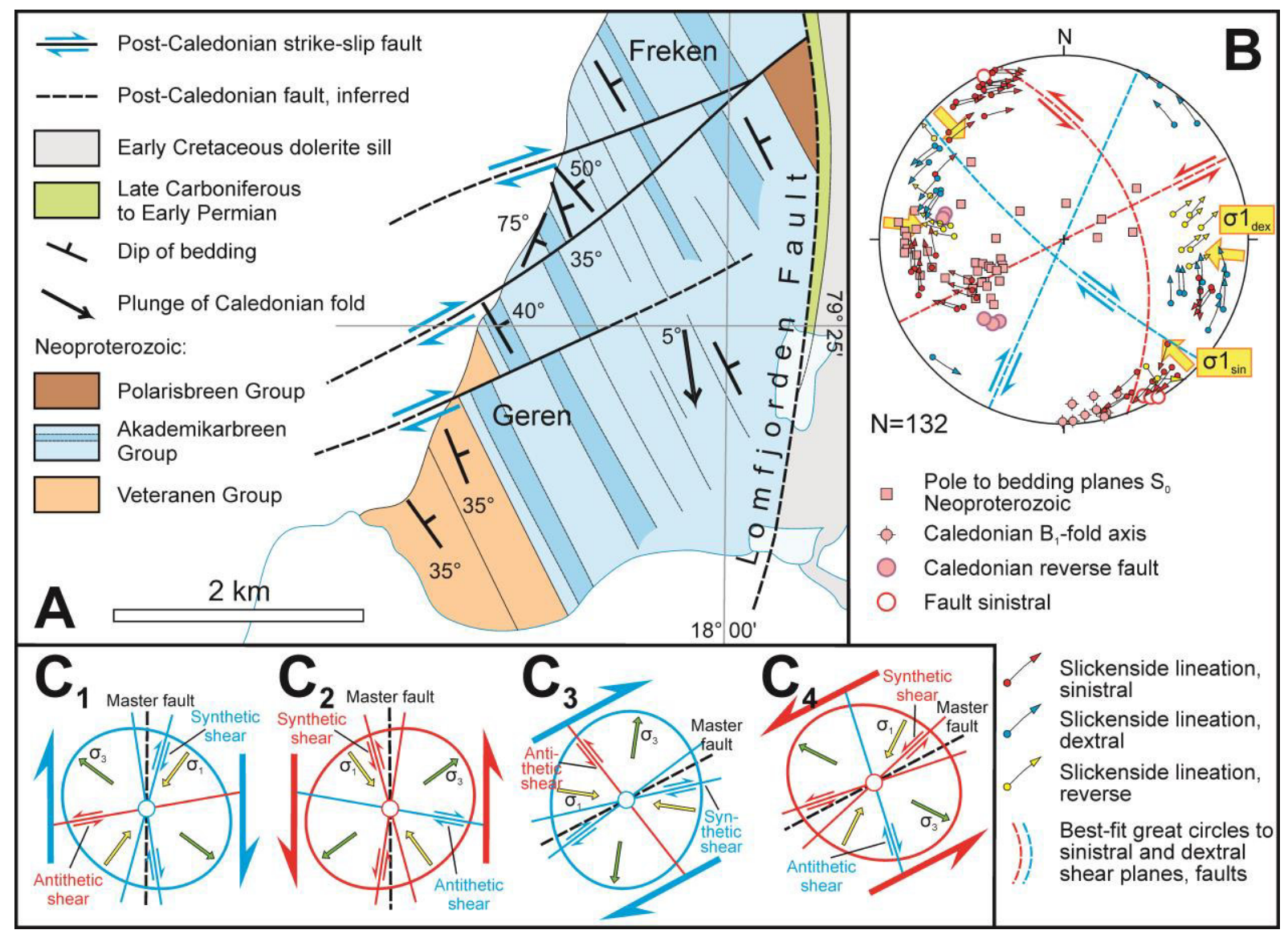

Figure 9 


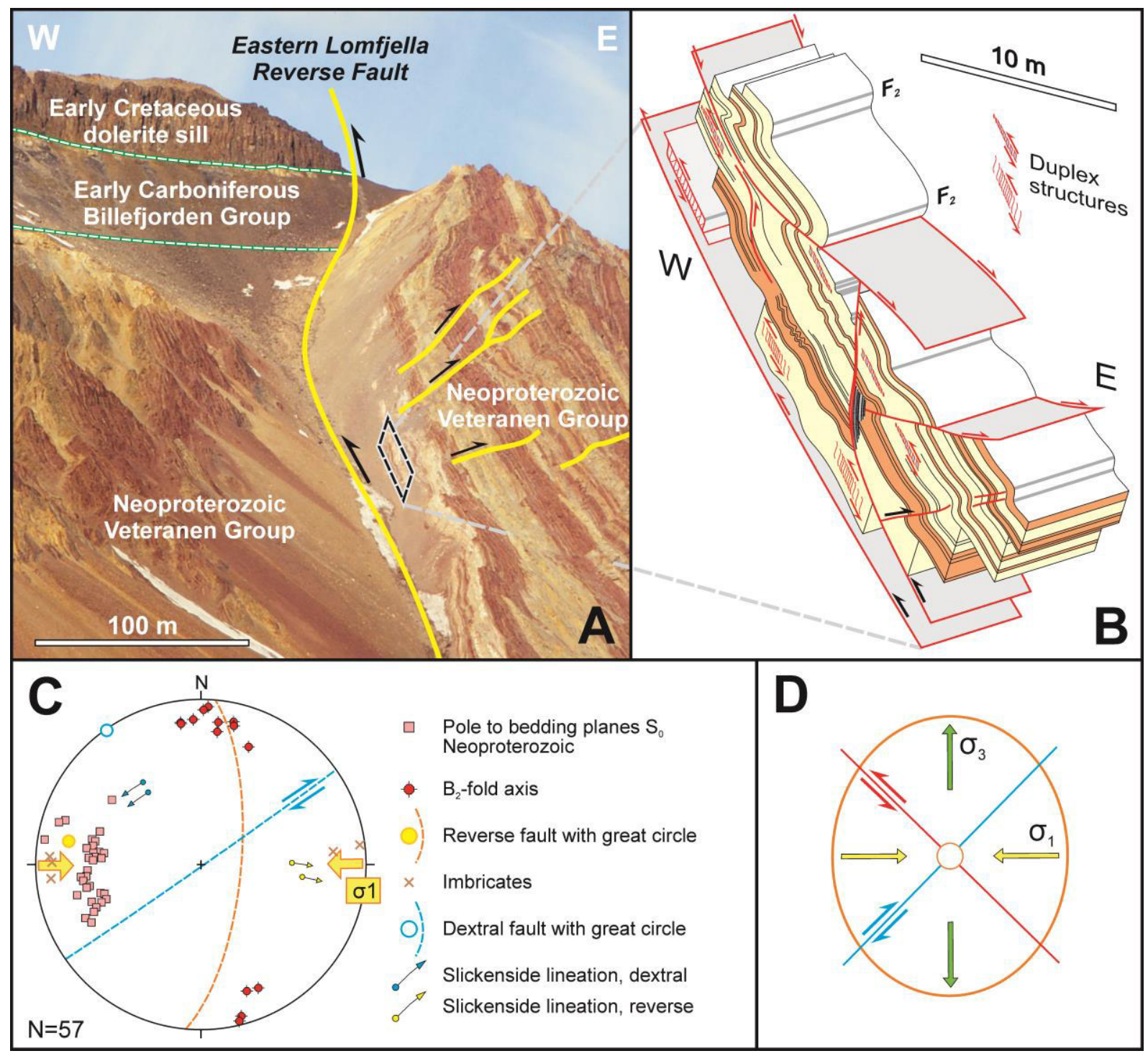

Figure 10 


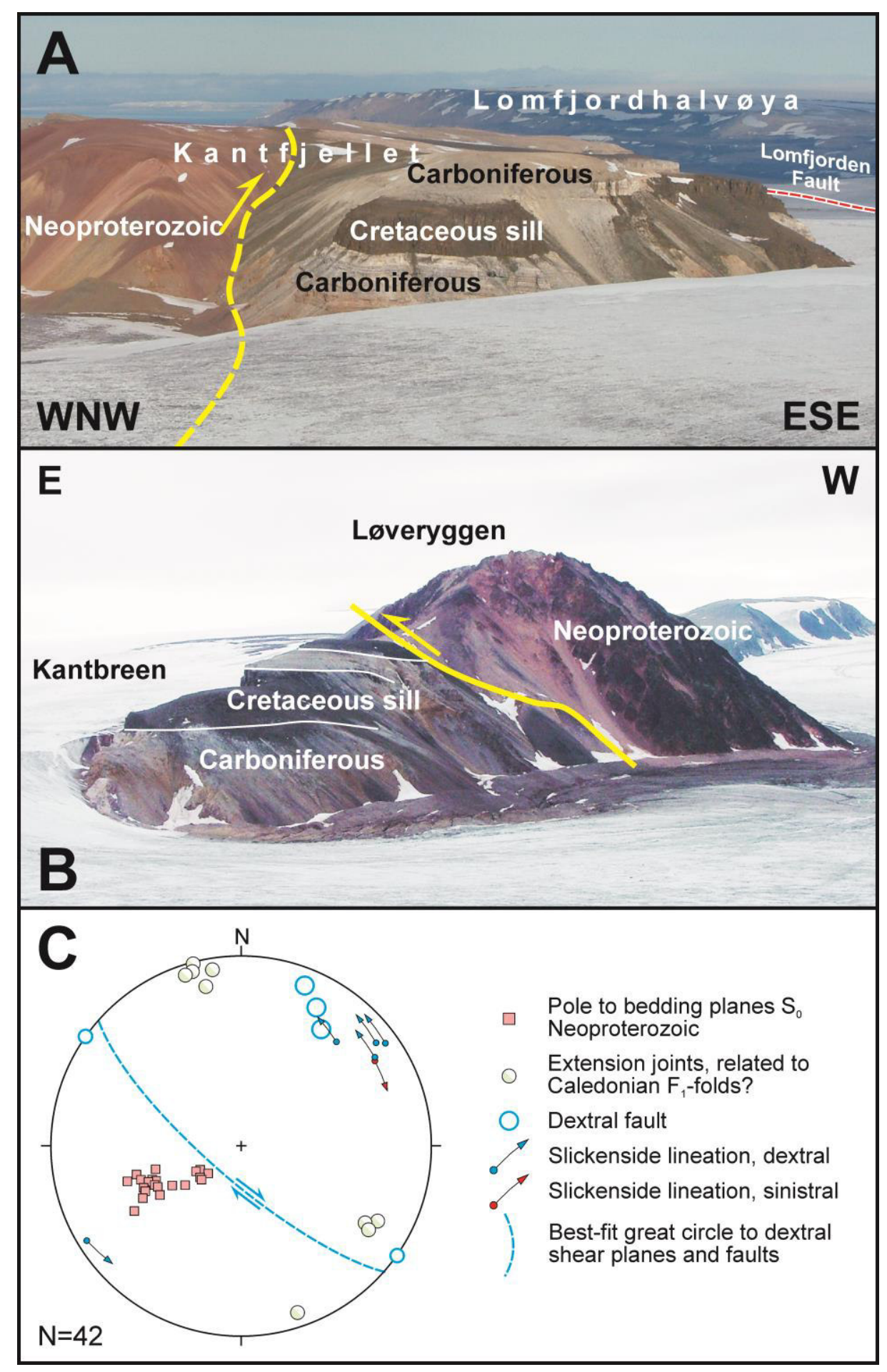

Figure 11 


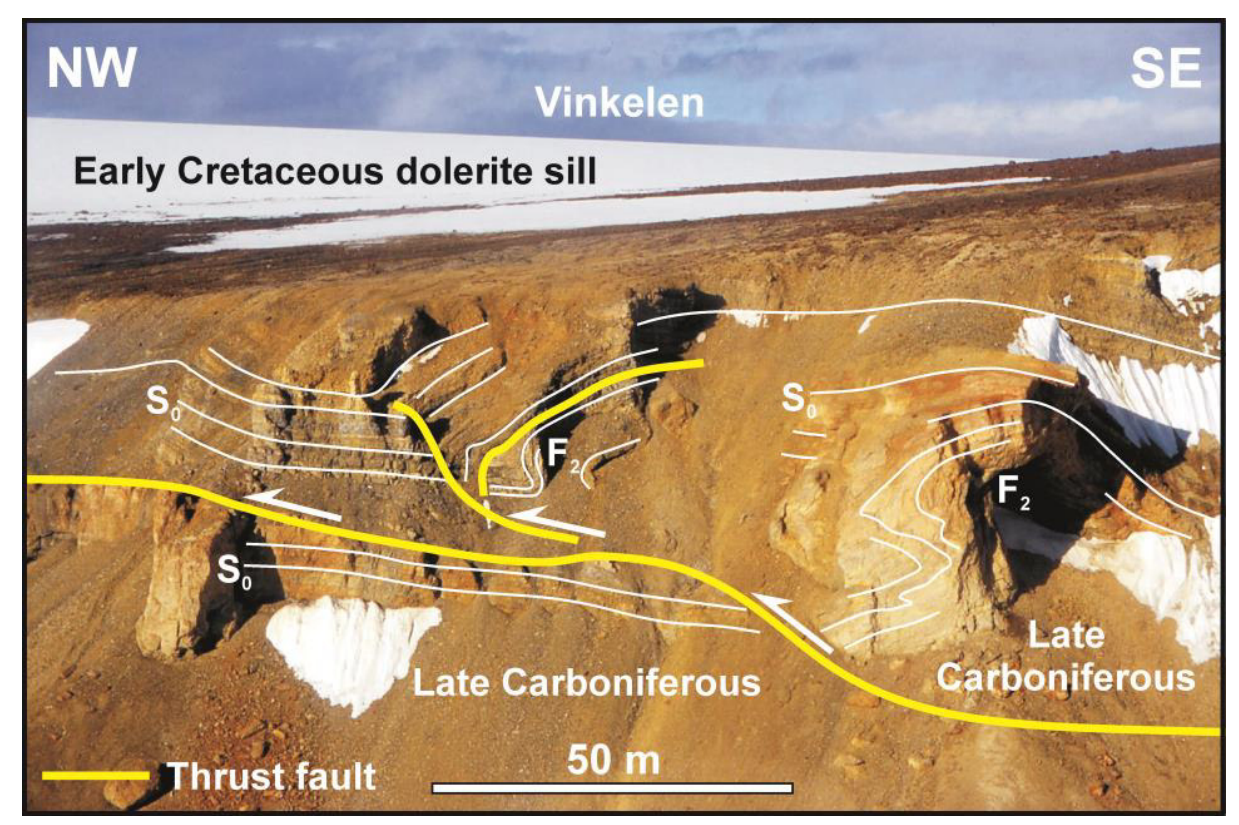

Figure 12 


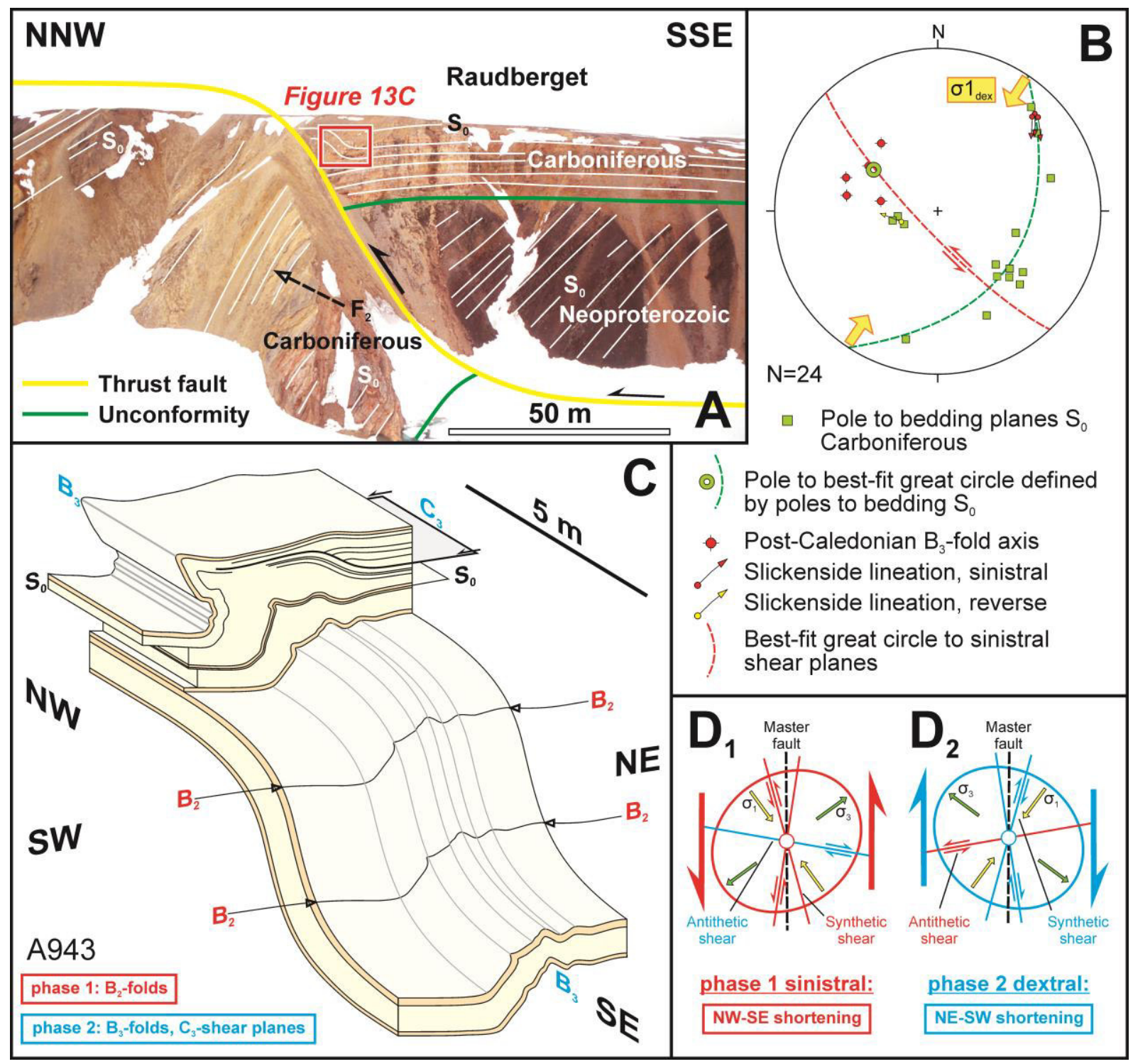

Figure 13 neu 


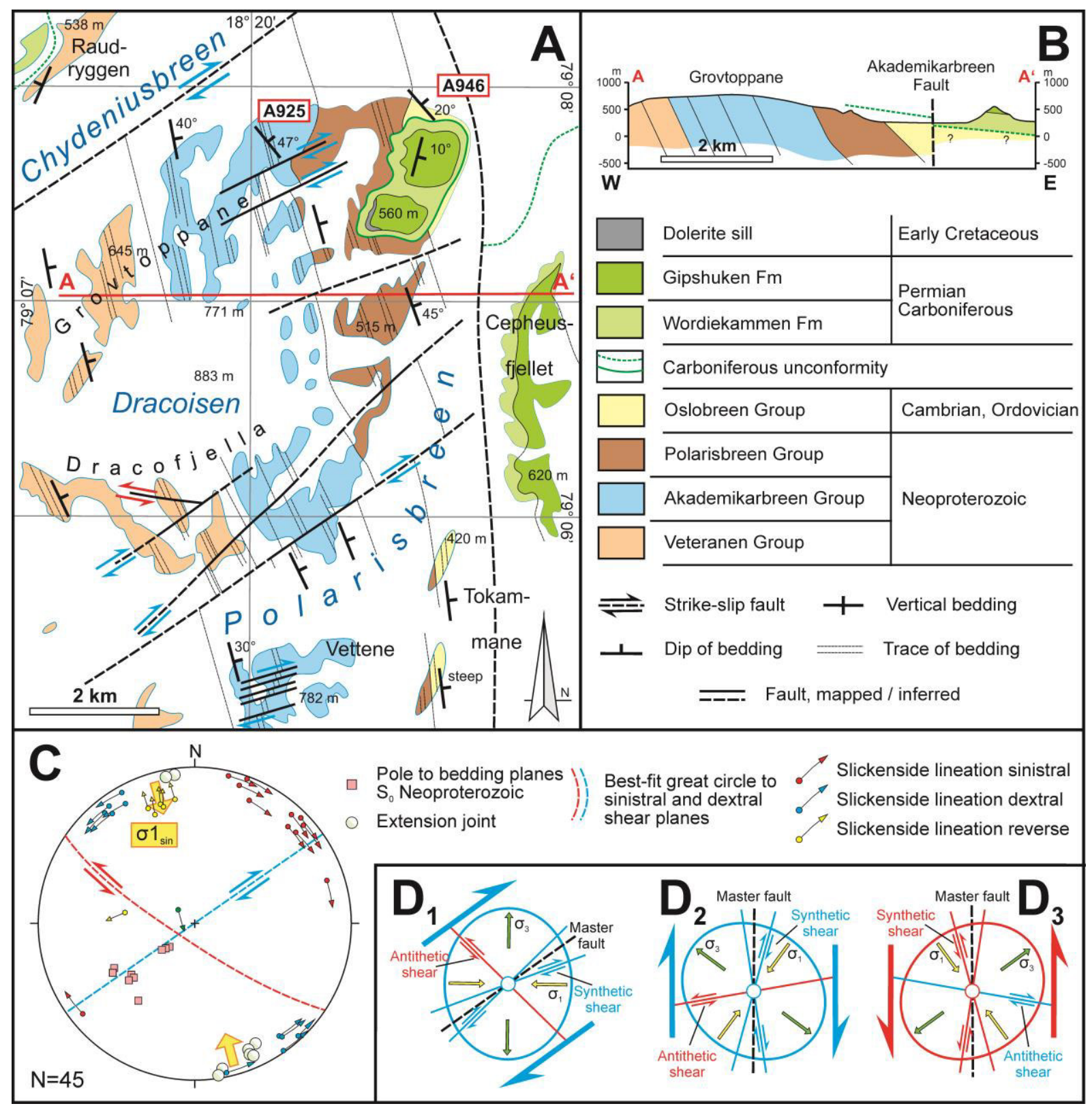

Figure 14 neu 


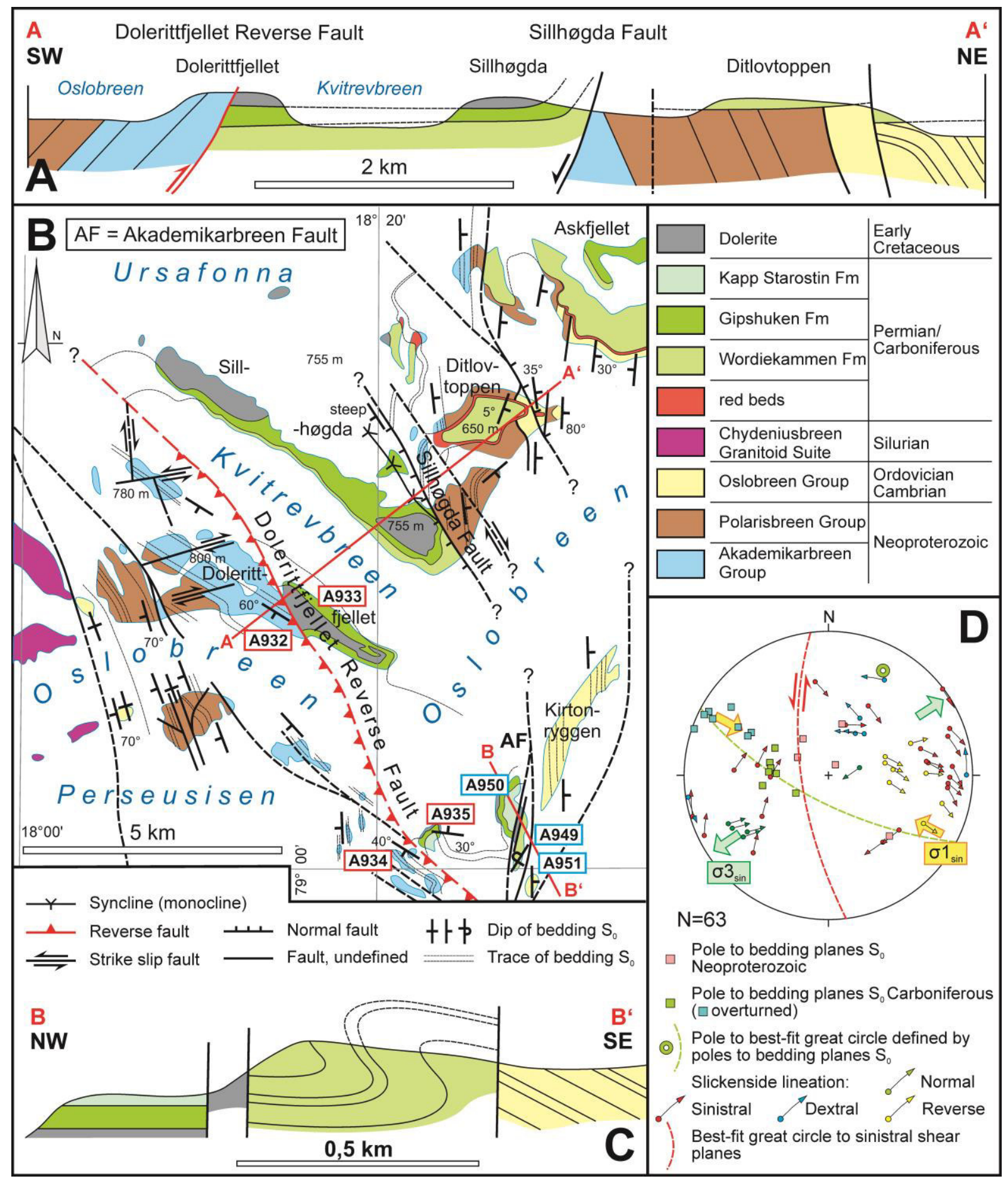

Figure 15 neu 


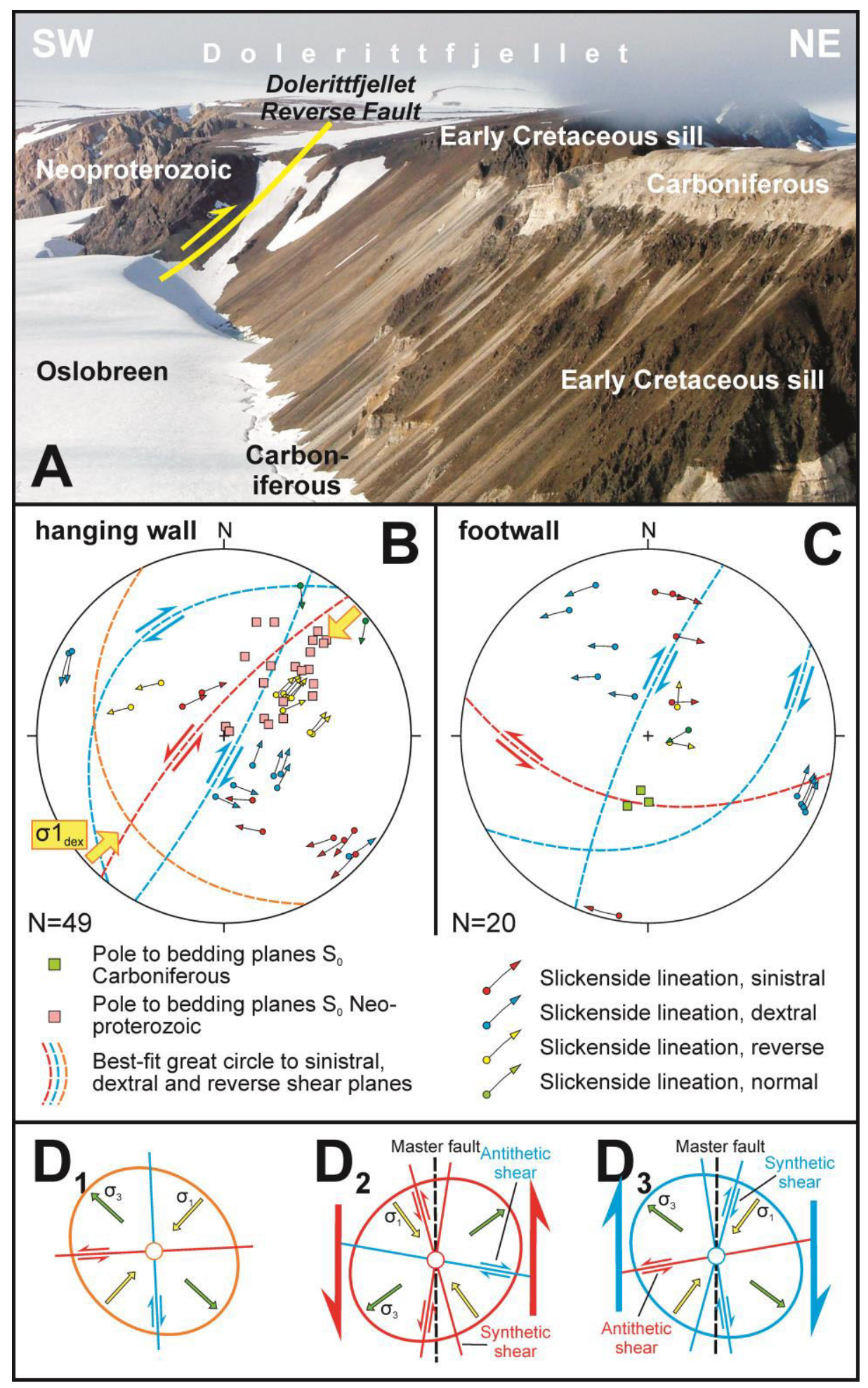

Figure 16 


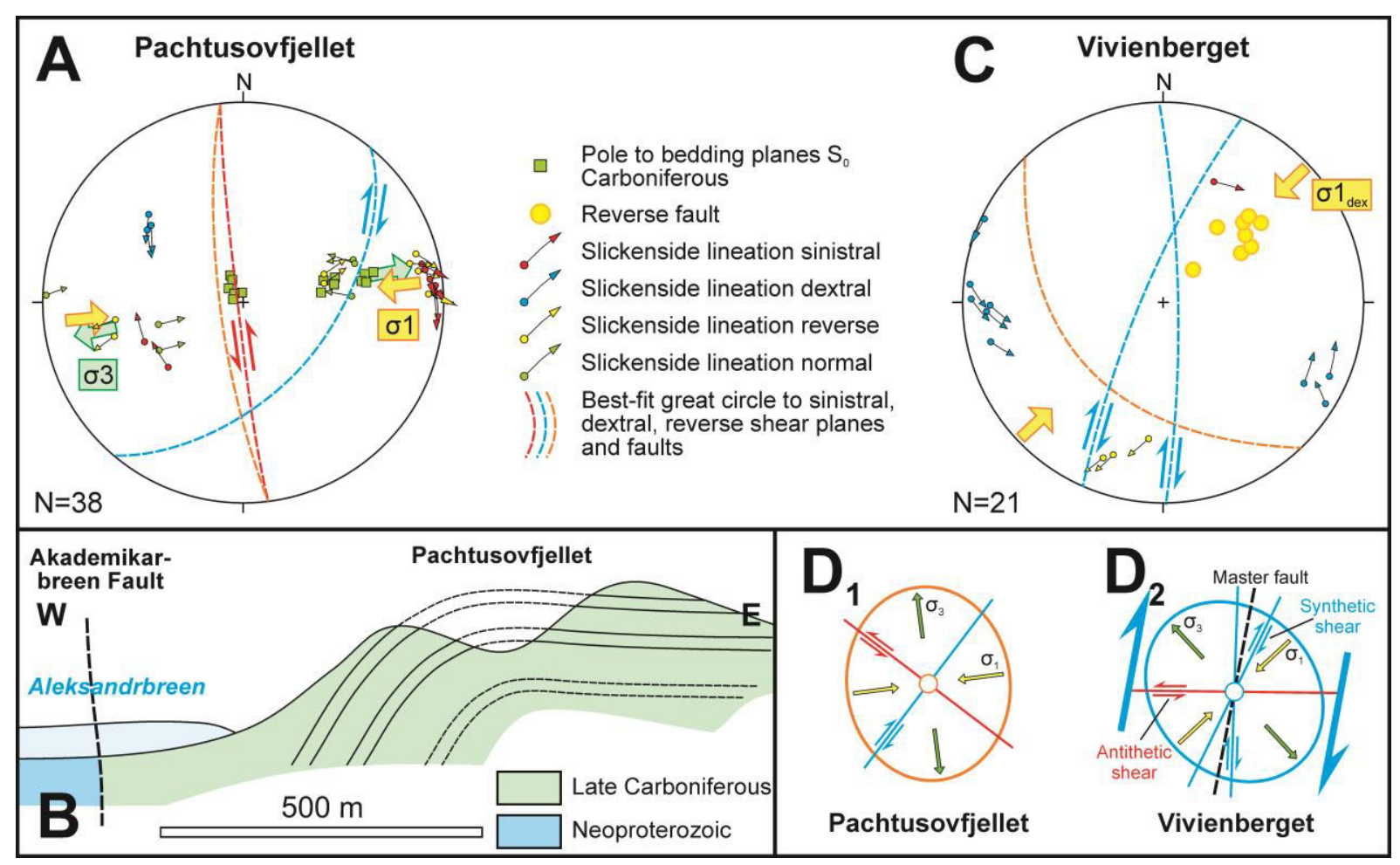

Figure 17 neu 


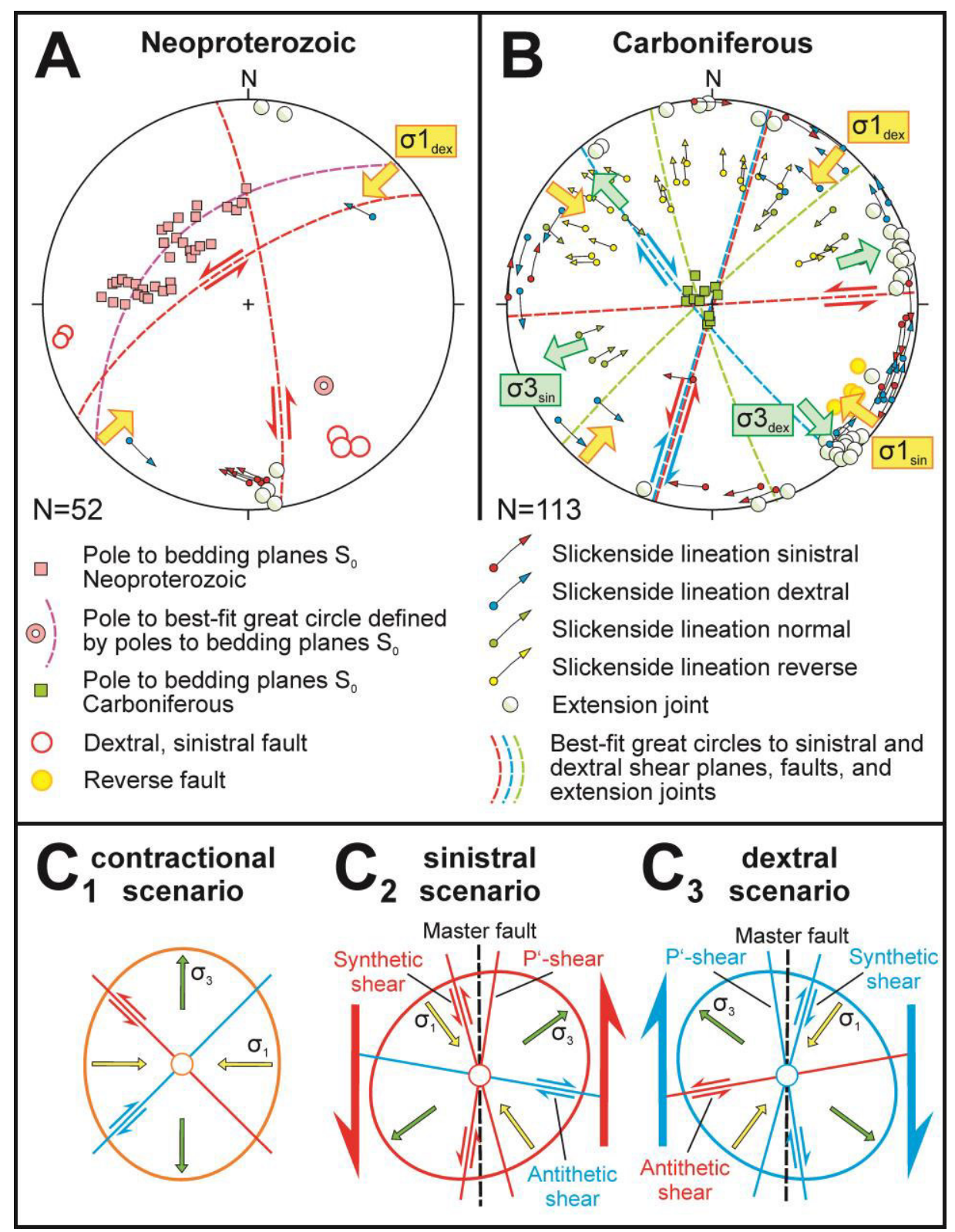

Figure 18 neu 


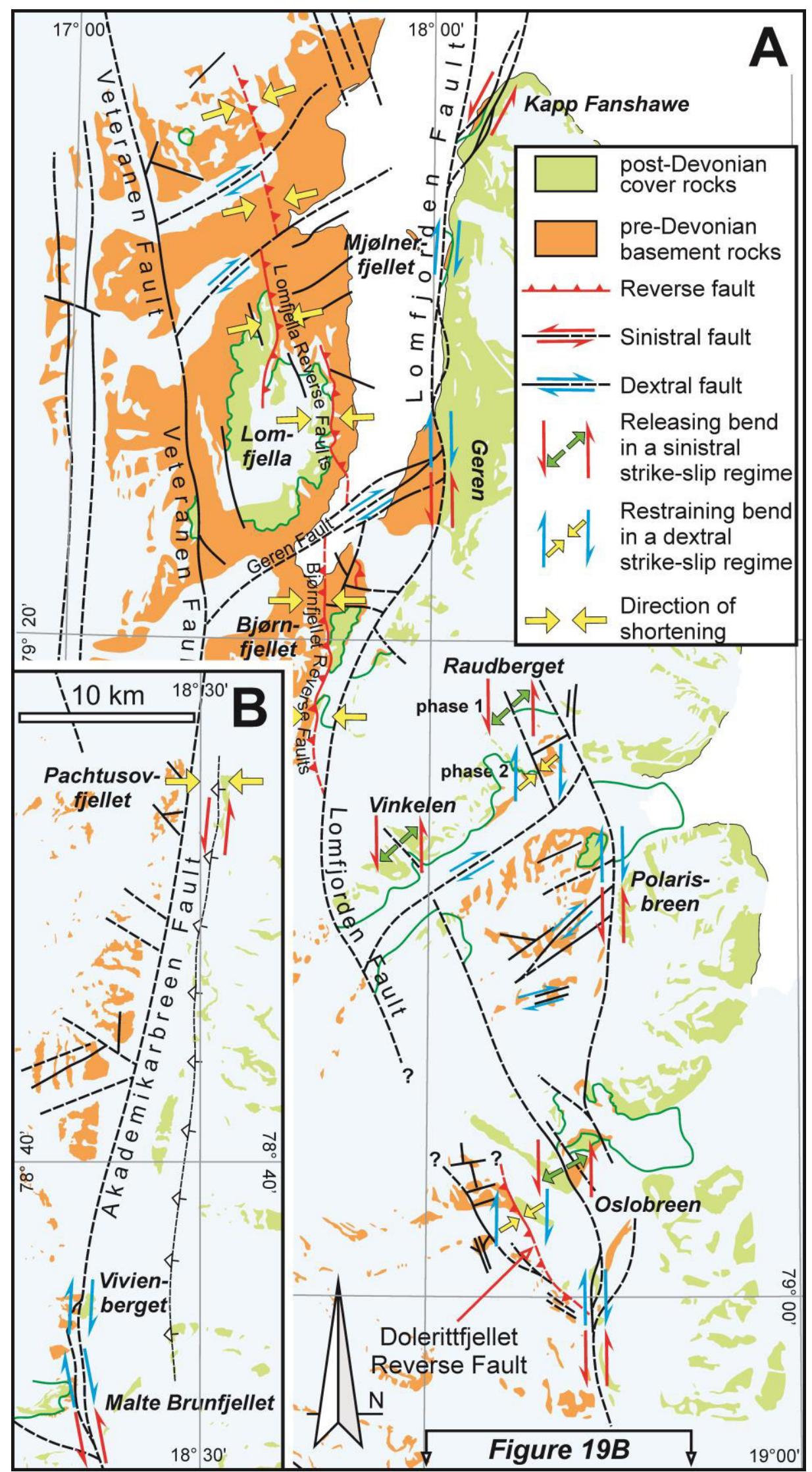

Figure 19 neu 


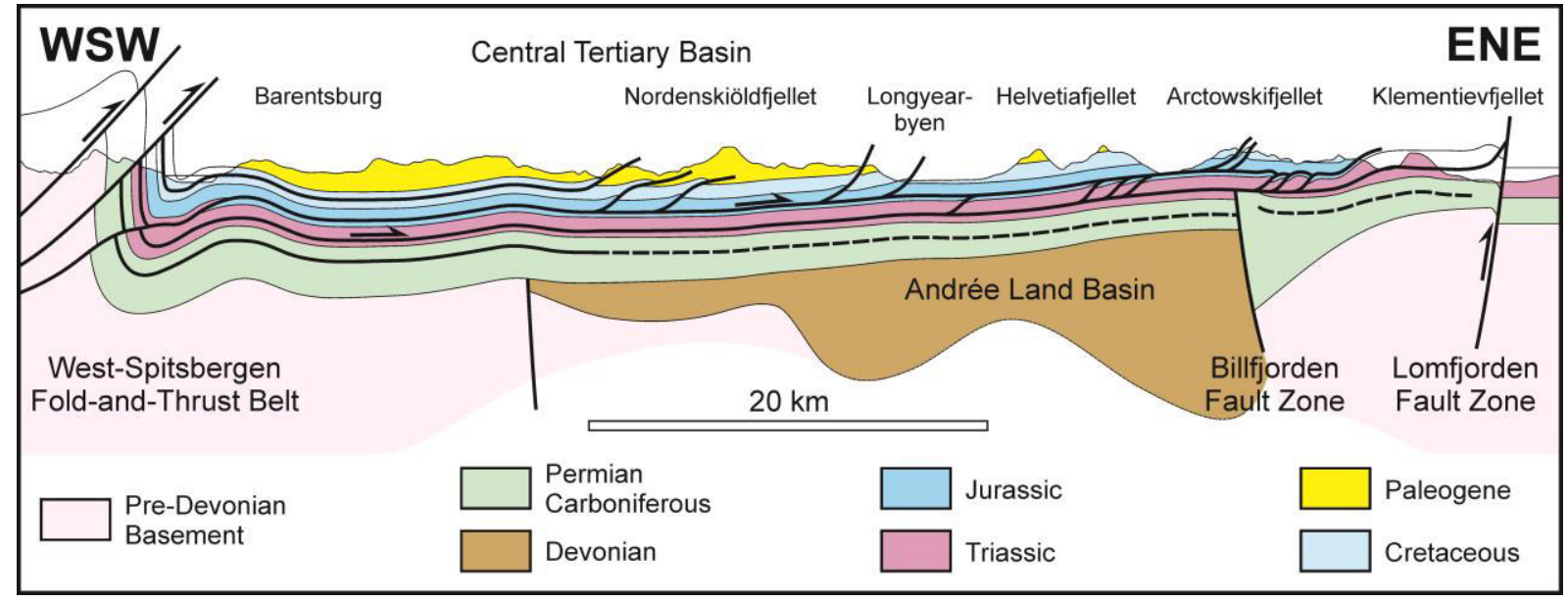

Figure 20 


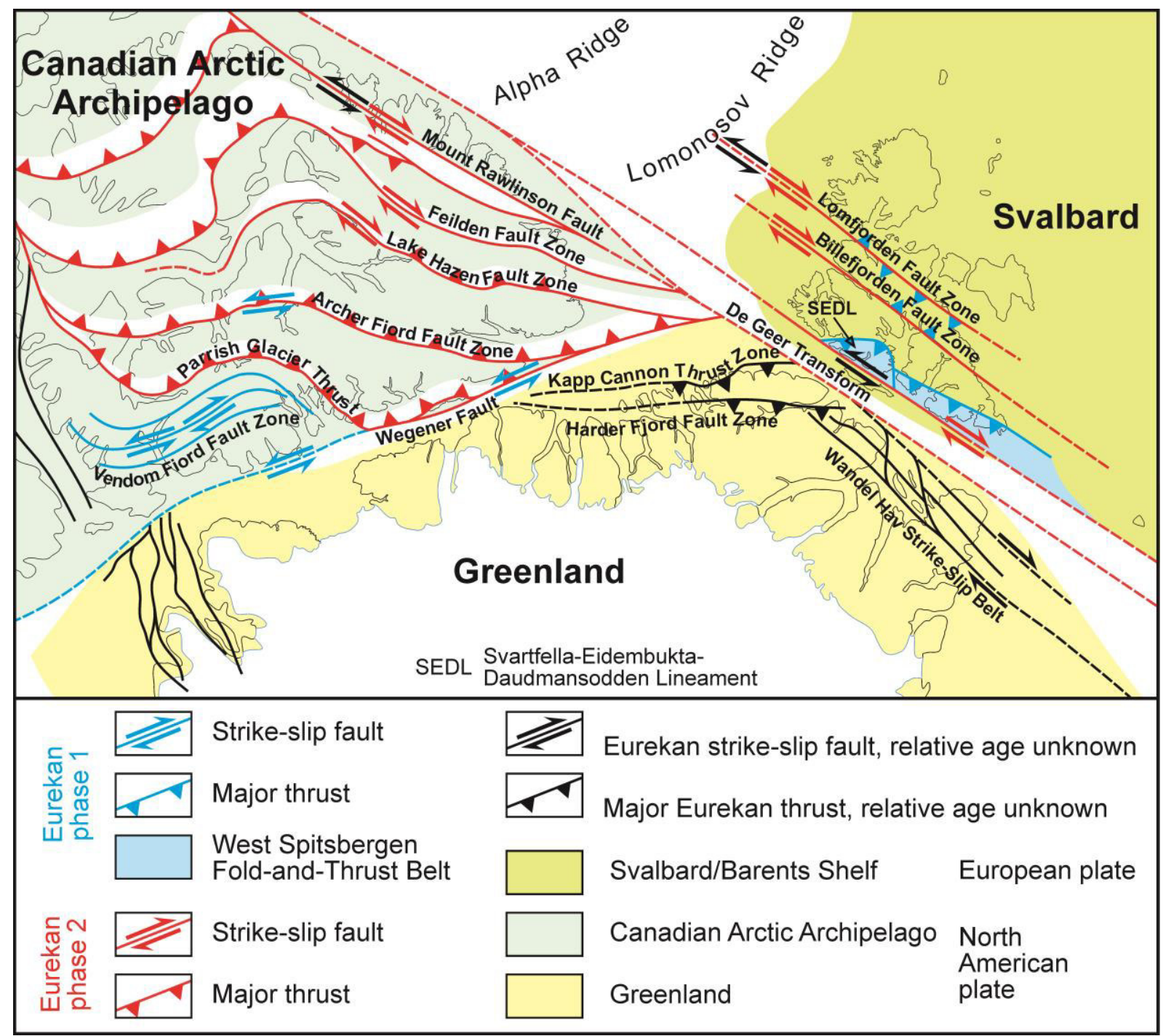

Figure 21 